\title{
Revision of Oxandra (Annonaceae)
}

\author{
Junikka, L.
}

2016

Junikka , L , Maas , P J M , Maas-van de Kamer , H \& Westra , L Y T 2016 , ' Revision of

Oxandra (Annonaceae) ' , Blumea , vol. 61 , no. 3 , pp. 215-266 . https://doi.org/10.3767/000651916X694283

http://hdl.handle.net/10138/224562

https://doi.org/10.3767/000651916X694283

cc_by_nc_nd

publishedVersion

Downloaded from Helda, University of Helsinki institutional repository.

This is an electronic reprint of the original article.

This reprint may differ from the original in pagination and typographic detail.

Please cite the original version. 


\title{
Revision of Oxandra (Annonaceae)
}

\author{
L. Junikka1', P.J.M. Maas², H. Maas-van de Kamer², L.Y.Th. Westra²
}

\author{
Key words \\ Annonaceae \\ Neotropics \\ Oxandra \\ taxonomy \\ vernacular names
}

\begin{abstract}
A taxonomic revision is given of the Neotropical genus Oxandra (Annonaceae). Within the genus 27 species are recognized, 4 of which are new to science. Most of the species are occurring in tropical South America, whereas a few (6) are found in Mexico and Central America and two in the West Indies (Greater and Lesser Antilles). A key to all species is provided. The treatment includes chapters about the history of the genus and morphology. All species are fully described, including full synonymy, notes on distribution and ecology, field observations (when available), vernacular names (when given), and mostly short notes about relationships of the species concerned. For each species a distribution map is made. At the end of the revision a complete list of vernacular names is included.
\end{abstract}

Published on 7 December 2016

\section{INTRODUCTION}

The genus Oxandra was first published in 1841 by A. Richard with the two species O. virgata (Sw.) A.Rich. (= O. lanceolata (Sw.) Baill. and O. laurifolia (Sw.) A.Rich. Oxandra was first classified by Baillon (1868a) in the tribe Anoneae Endl. and subtribe Uvarieae Baill. together with genera as, among others, Cananga, Sageraea and Uvaria. Later Prantl (1891) included Oxandra in the tribe Miliuseae Hook.f. \& Thomson with genera as, among others, Alphonsea, Bocagea and Miliusa. Both these treatments were based solely on floral characters. By the turn of the century eight Oxandra species had been described, some of which have been turned into synonymy later.

Fries (1931), the first monographer of the genus, described 17 species of which 6 were new to science. He considered the genus to be a very natural one ('sehr natürlich') and sharply delimited ('und ihre Grenzen sind scharf und klar'). As important features he gives imbricate petals, relatively few stamens and carpels, the stamens with an elongate prolongation of the connective, the carpels with only one basal ovule. Other features he mentioned are the axillary flowers, and very short pedicels, which are covered with 1-6(-more) distichous bracts. He based his key on leaf base, indument of young twigs, number of flowers, pedicel length, leaf shape and size and the shape of the primary vein (raised or impressed).

In his treatment of the family in the second edition of 'Die natürlichen Pflanzenfamilien' (Fries 1959) he placed Oxandra in the subfamily of Annonoideae, tribe Uvarieae, a tribe characterized by imbricate petals and distichous leaves. Within this tribe the genus is placed in the 'Asimina-Gruppe', a group featuring imbricate sepals and petals, and axillary flowers. Within the group Fries singled out Oxandra by $1(-2)$ basal ovules and a long apical prolongation of the connective. He distinguished 22 species and included a key to these species. This, essentially, did not add very much to Fries' earlier treatment of the genus. Walker (1971) in his study of the pollen morphology, phytogeography and phylogeny of the family of Annonaceae placed

\footnotetext{
${ }^{1}$ University of Helsinki, Botany Unit, FMNH, P.O. Box 7, 00014, Helsinki, Finland.

${ }^{2}$ Naturalis Biodiversity Center, section Botany, P.O. Box 9517, 2300 RA Leiden, The Netherlands;

corresponding author e-mail: paul.maas@naturalis.nl.
}

the genus in his Malmea subfamily and the Malmea tribe with Bocageopsis, Cremastosperma, Ephedranthus, Malmea, Onychopetalum, Pseudephedranthus, Pseudoxandra, Ruizodendron, Unonopsis, and the African genus Annickia (as Enantia, now placed by Chatrou et al. (2012) in the subfamily Malmeoideae, tribe Piptostigmateae). The group shares mostly solitary medium-sized to large $(39-81 \mu \mathrm{m})$ pollen grains, which are, among others, heteropolar, mostly bilateral, sulcate and boat-shaped.

Van Heusden (1992) put Oxandra in the Cremastospermagroup together with Cremastosperma, Ephedranthus, Malmea, Pseudephedranthus, Pseudoxandra and Ruizodendron, characterized by e.g. imbricate petals and sepals, (sub)equal petal whorls, simple hairs, 1 ovule per carpel and predominantly basal placentation. The two last character states are evident also in Van Setten \& Koek-Noorman's (1992) study of fruits and seeds of Annonaceae. They placed the genus in the informal Group 4 , in which seeds are transversely striate to pitted, and ruminations peg-shaped to lamellate. This group included five Asian genera and the following Neotropical genera: Cremastosperma, Ephedranthus, Malmea s.l., Pseudephedranthus, Pseudoxandra and Ruizodendron. It is noteworthy that the genus Oxan$d r a$ and these six genera were regarded closely allied in the above-mentioned Walker's (1971) and Van Heusden's (1992) studies. Fries' (1959) Asimina-group is made up of the same genera just mentioned including Oxandra, but with exception of Malmea s.l. and Pseudephedranthus.

Maas \& Westra (2003) in their revision of the Neotropical genus Pseudoxandra constructed a key to the 'Cremastosperma alliance', which includes the following genera: Bocageopsis, Cremastosperma, Ephedranthus, Klarobelia, Malmea, Mosannona, Onychopetalum, Oxandra, Pseudephedranthus, Pseudomalmea, Pseudoxandra, Ruizodendron and Unonopsis.

Phylogenetic research was carried out by Pirie et al. (2006) on the South American centred (SAC) clade, using maximum parsimony and Bayesian analysis. This clade comprises all genera of the so-called Short Branch clade (SBC) that occur in South America and to a limited extent in Central America. The results of their analysis, including 11 species of Oxandra, cast much doubt on the monophyly of Oxandra. Two well-supported clades containing only Oxandra emerge, one including $O$. asbeckii, O. euneura, O. polyantha, O. Iongipetala, O. espintana

\section{(c) 2016 Naturalis Biodiversity Center}

You are free to share - to copy, distribute and transmit the work, under the following conditions:

Attribution: $\quad$ You must attribute the work in the manner specified by the author or licensor (but not in any way that suggests that they endorse you or your use of the work).

Non-commercial: You may not use this work for commercial purposes.

No derivative works: You may not alter, transform, or build upon this work.
For any reuse or distribution, you must make clear to others the license terms of this work, which can be found at http://creativecommons.org/licenses/by-nc-nd/3.0/legalcode. Any of the above conditions can be For any reuse or distribution, you must make clear to others the license terms of this work, which can be found at http://crealive 
and $O$. nitida [now united with $O$. espintana], and the second clade containing O. laurifolia, O. macrophylla, O. sphaerocarpa and $O$. xylopioides. Morphologically, the first clade appears best distinct by a raised primary vein on the upper side (except in $O$. espintana where it varies from raised to impressed), and an impressed primary vein in the second clade (except in O. laurifolia with a flat primary vein). Surprisingly, $O$. venezuelana comes out sister to Pseudomalmea diclina.

The most recent infrafamilial classification is that by Chatrou et al. (2012), who placed the genus Oxandra in the subfamily Malmeoideae, tribe Malmeeae (clade $\mathrm{V}$ in their phylogram) together with the genera Bocageopsis, Cremastosperma, Ephedranthus, Klarobelia, Malmea, Mosannona, OnychopetaIum, Pseudephedranthus, Pseudomalmea, Pseudoxandra, Ruizodendron and Unonopsis (Chatrou et al. 2012; Fig. 1).
This group is characterized by simple hairs, bracts on the pedicel, rhipidiate inflorescences, terminal or axillary, bisexual or male flowers (plants androdioecious), mostly basal placentation, seed ruminations spiniform, in pegs, or lamellate, and monosulcate pollen. However, the relationships within the tribe Malmeeae, and especially concerning the species of Oxandra, are poorly resolved and generally unsupported. Because of lack of resolution, therefore, it is better not to make definite statements about relationship at this moment.

\section{MATERIALS AND METHODS}

Material for the study was provided from the following herbaria: AAU, ALCB, B, BP, BR, C, CEPEC, COAH, COL, CUVC, CVRD, DUKE, E, F, FHO, G, GB, GOET, GUA, H, HBG, HRB, HUA,

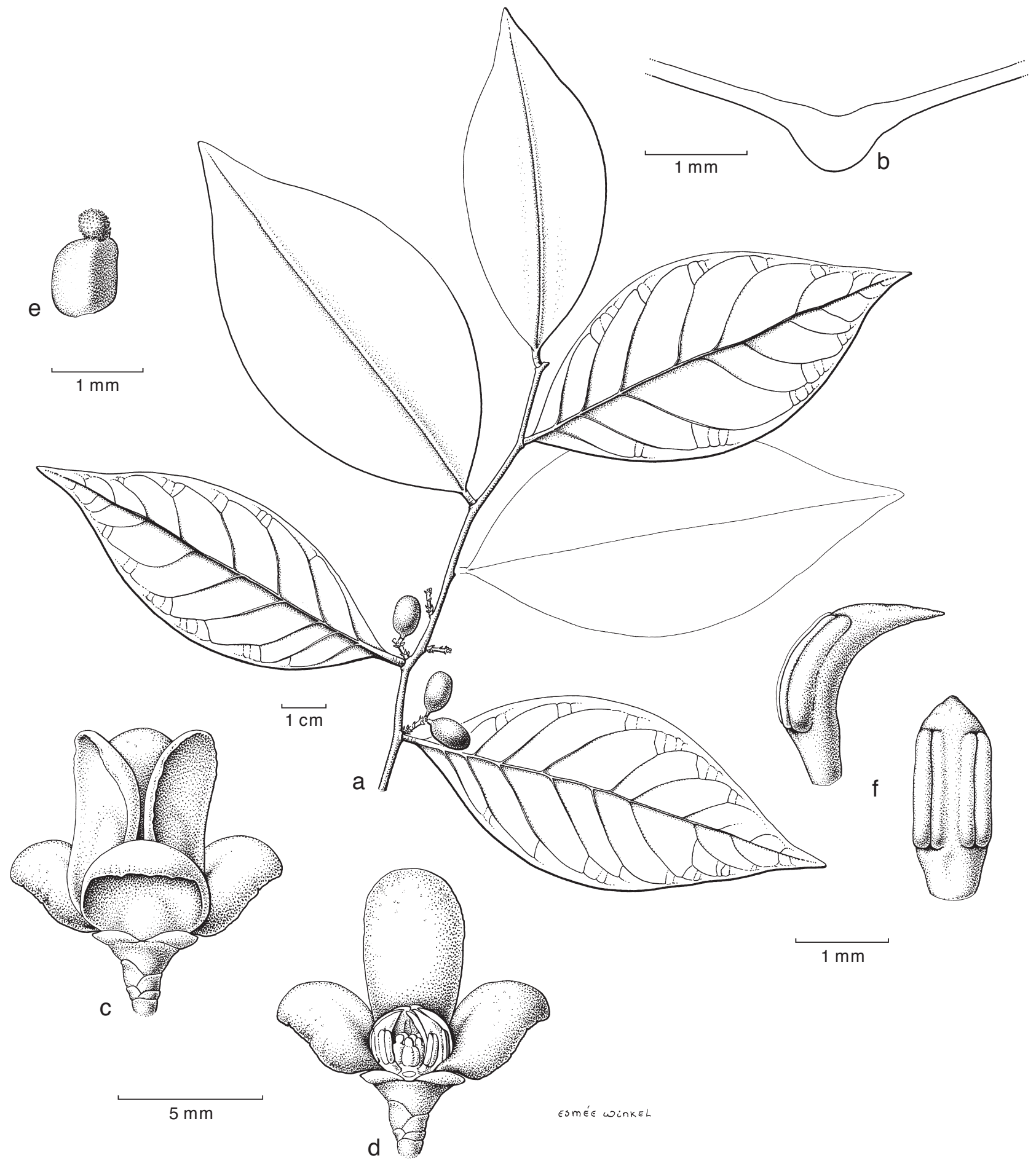

Fig. 1 Oxandra espintana (Spruce ex Benth.) Baill. a. Fruiting twig; b. cross section of leaf; c. flower; d. flower with part of petals removed; e. carpel; f. stamen (a, b: Chatrou et al. 145, U; c-f: Maas et al. 8821, U). — Drawing by Esmée Winkel. 
HUEFS, IAN, INPA, K, L, LE, LIL, LPB, MBML, MEXU, MG, $\mathrm{MICH}, \mathrm{MO}, \mathrm{NA}, \mathrm{NY}, \mathrm{O}, \mathrm{P}, \mathrm{PR}, \mathrm{R}, \mathrm{RB}, \mathrm{RUSU}, \mathrm{S}, \mathrm{SP}, \mathrm{SPF}, \mathrm{U}$, UC, ULM, US, VEN, VIES, WIS, WU, Z.

Measurements were done on representative herbarium specimens.

Colour and surface structures of the leaves were examined from dried specimens, flower and fruit colour in vivo were perused from data on the label, as was also done with vernacular names and local uses of a species. Some names were gathered from the literature.

For terms applying to shape we have consequently used the terminology recommended by the Systematics Association Committee for descriptive biological terminology (1962), Hickey (1979), Radford et al. (1974) and Stearn (1992).

\section{GENERAL MORPHOLOGY}

\section{Habit}

Oxandra species are mainly trees, the largest ones up to $50 \mathrm{~m}$ tall. More than half are small trees, less than $20 \mathrm{~m}$ tall, but only a few species may remain shrubs less than $3 \mathrm{~m}$ tall, e.g. O. rheophytica and $O$. surinamensis. Some of the tallest species are O. sphaerocarpa, O. venezuelana and O. xylopioides, which all can reach a height of $40 \mathrm{~m}$ or more. Oxandra trees are quite slender trees, only in seven species the trunk can exceed $50 \mathrm{~cm}$ diam, i.e. O. espintana, O. martiana, O. polyantha, O. saxicola, O. sphaerocarpa, O. venezuelana and O. xylopioides.

\section{Leaves}

Leaves are as in the great majority of Annonaceae simple, entire, petiolate, and leaf position is distichous, i.e. in two rows, which is apparent in lateral branches. Petioles are relatively short, no more than $5 \mathrm{~mm}$ long and $2 \mathrm{~mm}$ diam, except in $O$. venezuelana, in which petioles vary from $3-8 \mathrm{~mm}$ long. The shape of the lamina is mostly narrowly elliptic or elliptic, ovate or obovate. In few species the lamina may be rhombic (O. lanceolata, O. maya, O. riedeliana), oblong-elliptic (O. xylopioides) or linear (O. rheophytica). The texture is mainly chartaceous, but coriaceous leaves are not rare. The upper surface varies from dull to shiny, and is sometimes verruculose. Few species are reddish brown-punctate on the lower side of the lamina (e.g. O. reticulata, O. unibracteata). The lamina is mostly $5-20 \mathrm{~cm}$ long, the index varying from 1.6-10, but mostly between 2 and 4. The largest leaves occur in O. macrophylla, but in $1 / 3$ of the species they are less than $10 \mathrm{~cm}$ long, with the smallest leaves $5-6$ by $1.5-2 \mathrm{~cm}$ in an aberrant specimen (see Unplaced specimens). The apex of the lamina varies from long-acute to more or less acuminate (acumen 5-30 mm long), sometimes rounded, rarely emarginate (O. reticulata and $O$. sessiliflora). The base of the lamina varies from acute to attenuate and obtuse to slightly cordate in few species. Almost stem-clasping cordate leaves are present in O. longipetala. Some species, i.e. O. guianensis, O. panamensis and O. sphaerocarpa, have two angular to tooth-like projections near the base of the lamina, most notably in O. xylopioides. Usually the base of the lamina is symmetrical, but in some species, e.g. O. leucodermis and $O$. surinamensis, it is oblique. The primary vein varies from clearly raised to flat on the upper side of the lamina in most species, to impressed in some species. In e.g. O. euneura and O. krukoffii, although still raised, the primary veins seem to be impressed because of laminar tissue bulging upward. The venation is brochidodromous, i.e. secondary veins joined together in a series of arches (loop-forming). In O. euneura and O. krukoffii loops are lined-up in an undulating, distinct marginal vein, in other species a more obscure marginal vein may be noticed. The smallest distance between loops and margin is $1 \mathrm{~mm}$ in
O. unibracteata while it reaches to $3-5 \mathrm{~mm}$ in 0 . euneura and $5-7 \mathrm{~mm}$ in O. krukoffii. The secondary veins vary from 6 to 20 pairs, mostly 8-14. Oxandra macrophylla which has the largest leaves, also has the highest number of secondary veins (15-20). The other extreme is 0 . asbeckii with only 6-7 pairs. The angle of secondary veins with the primary vein is from $40^{\circ}$ to $80^{\circ}$, very often there is much variation in the angle going from the base to the apical end of the lamina. Sometimes a single secondary vein deviates from the neighbouring secondary veins. The unplaced specimen mentioned earlier has secondary veins forming an exceptionally narrow angle of only $40-50^{\circ}$ with the primary vein. In a few species the secondary veins are indistinct, difficult to see with the naked eye. Tertiary veins are mostly distinct and almost always reticulate (except $O$. macrophylla, which shows some signs of percurrent tertiary veins). Only a few species, such as O. guianensis and O. xylopioides have indistinct, almost invisible tertiary veins.

\section{Indument}

Most Oxandra species possess hairs on their leaves, particularly in a young stage, but often become glabrous later. About half of the species have erect and/or appressed hairs on the lower side of the lamina. In several species there occur large, whitish, appressed hairs, mainly on the primary vein below. Only one species sometimes shows scattered hairs on the upper side of the lamina. However, in O. macrophylla and O. sphaerocarpa the primary vein has erect hairs on the upper side, which may remain for some time and can be an aid in identification.

\section{Bark}

Outer appearance of tree barks is usually smooth to rugose when young, later usually shallowly fissured. Fissures are boatshaped or oblique. More rarely barks are scaly, which may be formed in the exposed sites, where sun scorches the bark surface. Lenticels seem to be common in young barks. Barks are mainly thin or very thin, when compared with other rainforest trees (Roth 1981).

The description of bark anatomical features in Oxandra follows Junikka \& Koek-Noorman (2007).

Bark samples taken show the proportion of the bark increasing with a larger tree diameter. This is contradictory to what is commonly seen in the family Annonaceae in which the proportion of the bark is diminishing as the trunk thickens. The inner bark is the major component of the bark. Its portion is always more than $3 / 4$ of the whole bark tissue, often over $90 \%$.

In the periderm, which is composed of phellogen and its derivatives, phellem is dominant, which is a common tendency in many Annonaceous taxa in the Neotropics. The amount of phelloderm cell layers seems to be quite variable, i.e. 1-9 layers, where the average is 3-7 layers. Usually in the genus Oxandra phelloderm cells are thin-walled or only few cells are sclerified. Phellem is more developed and over 10 cell layers are often detectable. Thin-walled cells are lacking and sclerification is typically U-shaped, which is a common feature in the Neotropical members of the family. Secretory cells are lacking in sclerified cells of the phellem, but there are some secretory cells in phelloderm, either solitary or as irregular groups or tangential rows. Cortex, when present, is partly sclerified. Sclerification can be found as solitary cells, in various groups or in bands. In some species secretory cells are seen both solitary and in tangential bands/rows.

Rays near the cambium are narrow, multiseriate, $2-6$ cell layers wide, but widen towards the external part of the phloem, mainly irregularly. Rays are over $1 \mathrm{~mm}$ high and homogeneous, which is also a characteristic feature of the family, except in the genus Duguetia (Maas et al. 2003) which is weakly heterogeneous. 
The number of rays $/ \mathrm{mm}$ is more than 5 , which is clearly above average. Sclereids can be detected as solitary cells or variously grouped. Secretory cells are usually found as solitary cells or in tangential rows/bands.

Axial phloem is composed of fibers, secretory cells, sieve tube members (+companion cells) and axial parenchyma cells. Fibers are non-septate, occurring as compact groups superposing each other. Fiber groups form regular, wide, 3 or more cell layers thick, oblong or square-shaped tangential bands when seen in the cross section. Sclereids often accompany groups of fibers, but some taxa show a distinct pattern. Sclereids may be in radial arrangement on the adaxial side of the fiber groups, but sclereids on the abaxial side occur only in the genus Oxandra. Secretory cells are common and scattered as solitary cells or in small groups, rarely as bands/rows.

Crystals are frequently found in the majority of the Neotropical taxa of the family studied. Almost all crystals found in Oxandra barks are prismatic, i.e. of the octa- or rhombohedral type, c. 4$45 \mu \mathrm{m}$ in size. Other types are elongated or irregular crystals. Prismatic crystals are almost always found in sclereids, which may occur in phelloderm, cortex, rays, or axial phloem. These crystal-filled sclereids are located along fiber groups on the abaxial side in long vertical chains, rarely in short chains. The crystal-containing cells laterally associated with fiber groups are clearly enlarged, chambered, i.e. one crystal in a cell is filling its compartment almost totally.

\section{Inflorescences}

The genus Oxandra is fairly easy to recognize by its generally axillary inflorescence, short pedicels, and often high number of bracts. The flowers or (small) inflorescences are found in the axils of leaves, and may persist on older branchlets after the leaves have fallen. Fries (1959: 13 and onward) discusses the inflorescence architecture of Annonaceae with special emphasis on the place of the articulation and the position and number of bracts in relation to the articulation. He distinguishes three types of inflorescence architecture. Oxandra falls within the second category characterized by pedicels with one bract above the articulation, and a (varying) number of bracts below the articulation (e.g. Fig. 4d, 13b, h). This, by the way, is an important difference with the closely resembling (but not closely related) genus Pseudoxandra (Maas \& Westra 2003), in which there is no bract above the articulation (the first category of Fries). The number of bracts commonly varies between 4-7, or rarely more: up to 12 bracts in, e.g., O. martiana. An exception is $O$. reticulata with $1-2$ bracts, and the most extreme is the recently described $O$. unibracteata with a single bract ${ }^{1}$.

The only exception to the axillary flower position (as far as now known) is $O$. aberrans described in the present paper with terminal flowers, though shifting to a leaf-opposed position due to overtopping by the axillary shoot (like in e.g. Annona, Duguetia; Fig. 4a). (In the other species a false impression of a terminal flower may incidentally result from abortion of the vegetative apex: examine carefully!).

Secondary flowers are formed in the axils of bracts usually close to the base of the pedicel resulting in inflorescence formation. The pedicels of secondary flowers resemble the pedicel of the first flower, although sometimes with fewer bracts (e.g. Fig. 4b, 13c, g, 21a). Mostly the number of flowers seen in an inflorescence at a given time is low, up to about four, but in a few species it can be $\geq 10$ (e.g. O. polyantha, O. riedeliana). The second mode of inflorescence formation is through development from an accessory bud. This occurs in many diverse genera of

In a key to genera of the Cremastosperma alliance Maas \& Westra (2003) key out Oxandra with '0-several bracts above the articulation'. This is not correct as Oxandra has just one bract above the articulation.
Annonaceae (e.g. Guatteria; Maas et al. 2015) and very likely in Oxandra, too. The highly compact base of inflorescence clusters in Oxandra spp. makes it very difficult to determine the exact origin of such inflorescences with a hand lens alone and specialized anatomical research is needed (e.g. Fig. 4f).

\section{Flowers - Fig. 1}

Flower buds are either globose or ellipsoid - both shapes are equally common. Flowers are bisexual and/or male in androdioecious species (O. martiana, O. maya, O. mediocris and O. panamensis). Sepals are free, imbricate, broadly to shallowly ovate or ovate-triangular. Only in $O$. unibracteata the sepals are connate for up to half of their length. The three sepals range from 1-3 $\mathrm{mm}$ long, rarely larger. The six petals are free, imbricate, usually white, cream-coloured or yellow, sometimes green. The petal size varies from $5-10$ by $2-5 \mathrm{~mm}$, but sometimes more, e.g. in O. longipetala $(12-22$ by $3-7 \mathrm{~mm})$ and O. venezuelana ( $8-14$ by $4-7 \mathrm{~mm}$ ). The outer side of the petals varies from glabrous to hairy. Oxandra aberrans has 'spongy', $1.5-2.5 \mathrm{~mm}$ thick petals, which is a unique feature in the genus. Stamens usually number $10-25$, but $O$. aberrans and O. venezuelana stand out from others having c. 50 stamens in a flower. The apical prolongation of the connective is quite distinct and is often narrowly triangular, but it varies to ovate, depressed ovate, or quadrangular. Carpels are free, few to many, 0.8-1.5 mm long, glabrous or hairy, style absent, stigma spheroid, hairy, ovule 1, basal. Endress \& Armstrong (2011) in a study on Anaxagorea crassipetala showed that the spiral arrangement of stamens and carpels actually is the result of a (complex) whorled phyllotaxis. They conclude that Annonaceae are homogeneous in their whorled phyllotaxis.

\section{Fruit}

The fruit of Oxandra is apocarpous and composed of $1-25$, free, indehiscent monocarps. The wall of the monocarps (pericarp) is green to yellow or glaucous green, turning purplish and finally orange-red to black in vivo, and black or brown in sicco; it is generally glabrous, rarely covered with appressed to erect hairs. The shape of the monocarps is ellipsoid, ovoid, globose, (broadly) obovoid or narrowly ovoid-oblongoid, circular in transverse section and $7-30$ by $5-25 \mathrm{~mm}$. The apex is rounded or apiculate (apiculum 1-2.5 mm long); the wall of the monocarps is $0.2-3 \mathrm{~mm}$ thick. Each monocarp is generally placed on top of a stalk, termed stipe. These stipes measure $1-16$ by $1-2$ $\mathrm{mm}$, but can be absent.

Each monocarp is 1-seeded. The seed is basally attached and not arillate. The wall of the fruit (pericarp) is generally firmly attached to the outer layer of the seed wall, making it very difficult to separate them (Fig. 2b). Therefore the seed wall is often covered with remnants of the fruit wall (Van Setten \& Koek-Noorman 1992). The seed wall or testa is generally pale to dark brown or reddish brown; sometimes small dark dots can be seen on the surface. Its surface is transversely striate (Fig. 2d) or minutely pitted (Fig. 2f), but can be both pitted and striate in different parts of the surface. The shape of the seed is ellipsoid, globose, obovoid or oblongoid, measuring from $7-30$ by $4-15 \mathrm{~mm}$. A cross section of the seed shows ruminations that are spiniform (Fig. 2a), peg-shaped (Fig. 2c), or lamellate in 4 parts (Fig. 2e). Not all seeds with spiniform (to peg-shaped) ruminations have a pitted surface, but often these types of ruminations are found in combination with a transversely striate surface.

\section{DISTRIBUTION AND ECOLOGY}

The genus Oxandra is distributed from the Mexican states Nayarit and Veracruz to the Brazilian states of Rio de Janeiro and 


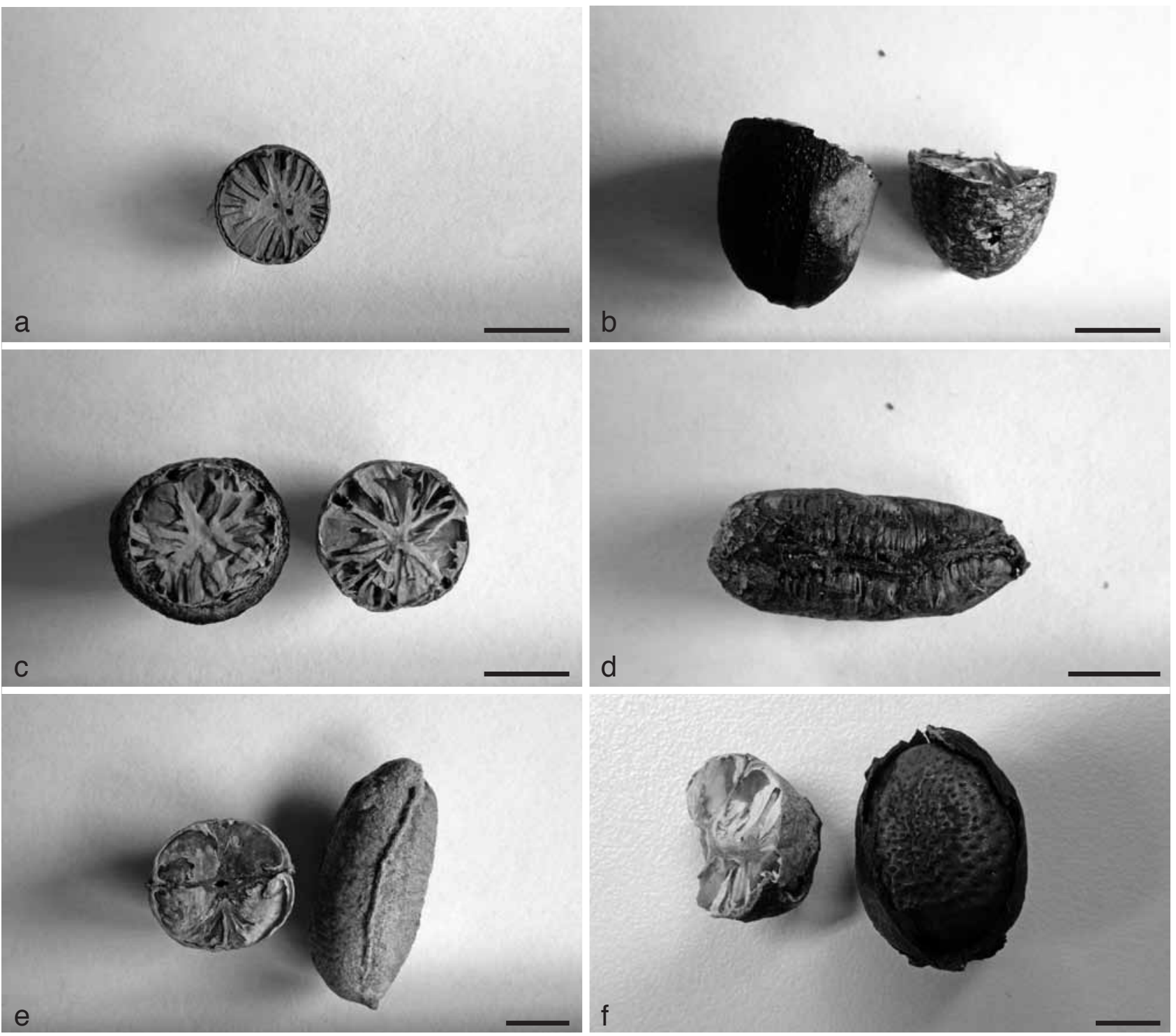

Fig. 2 Seeds of Oxandra. a. O. mediocris Diels; b, c. O. asbeckii (Pulle) R.E.Fr.; d. O. venezuelana R.E.Fr.; e. O. reticulata Maas; f. O. unibracteata J.C.Lopes, Junikka \& Mello-Silva (a: Maguire et al. 56768, U; b, c: BW 3129, U; d: Matuda 18483, F; e: Harley et al. 16751, L; f: Folli 545 , U). - Scale bars $=0.5 \mathrm{~cm}$.

Minas Gerais, and to Bolivia. In the Antilles only two species are commonly found, viz. O. lanceolata which occurs in the Greater Antilles and Mexico, and O. laurifolia which occurs in the Greater and Lesser Antilles. In Central America several species occur of which O. maya seems to be related, at least morphologically, to O. lanceolata. Other species occurring in Central America are O. Iongipetala, O. panamensis and O. venezuelana. The three last-mentioned species reach into Colombia and/or adjacent countries. Close to the Panamanian isthmus in Colombia $O$. bolivarensis and $O$. rheophytica are found. The largest number of Oxandra species (c. $40 \%$ of the total number) can be found in Western Amazonia (Ecuador, Peru, Colombia, Venezuela, Brazil and Bolivia), viz. O. asbeckii, O. espintana, O. euneura, O. krukoffii, O. leucodermis, O. macrophylla, O. mediocris, O. polyantha, O. riedeliana, O. sphaerocarpa and O. xylopioides. In the Guianas there are two endemic species, O. guianensis and $O$. surinamensis. Oxandra asbeckii has its distribution center in the Guianas, but it spreads also to the Amazon basin. In the eastern part of the Amazon basin there are fewer species, viz. O. riedeliana, O. polyantha and O. krukoffii. In the north-eastern part of Brazil some interesting species inhabit dry forests, viz. O. reticulata, O. saxicola (also in Bolivia) and O. sessiliflora. In the south-eastern part of Brazil O. martiana and O. espintana (now also including O. nitida) occur.
Oxandra espintana is by far the most widespread species in the genus occurring in the western Amazon basin and northern South America (including the island San Andrés of Colombia) and in the Atlantic Forests in the states Rio de Janeiro, Espírito Santo, Minas Gerais and Bahia. This type of disjunction of O. espintana between the Atlantic rainforests of Brazil and andean regions extending into the Guianas is not unique. Another example in Annonaceae is Cymbopetalum brasiliense (Vell.) Benth. ex Baill. which occurs in the Guianas, Trinidad, eastern and southern Venezuela, northern Amazonia, northern Bolivia and adjacent Rondônia, Brazil, and Madre de Dios in Peru (Murray 1993). A further example are e.g. several species of Costus (Costaceae).

Most Oxandra species inhabit more or less humid, terra firme rainforests, but some species thrive also in periodically inundated forests. Igapó forests, which are formed in flooded forests of black and clear water rivers, can house $O$. euneura, $\mathrm{O}$. leucodermis, O. mediocris, O. polyantha and $\mathrm{O}$. riedeliana, and in more fertile soils, so-called várzea, formed by flooding with muddy water rivers, occur O. macrophylla, O. mediocris, $O$. polyantha, O. riedeliana, O. sphaerocarpa and O. xylopioides. In drier forest types, such as cerrado, caatinga and campinarana, one can find $O$. asbeckii, O. reticulata, O. saxicola and $O$. sessiliflora. Usually the soil is clayey and acid. Some species 
thrive in calcareous soils, e.g. O. maya and O. saxicola, or in nutrient-poor white sands, e.g. O. asbeckii, and even O. leucodermis and $O$. polyantha, which are also found growing in igapó and/or várzea forests.

Oxandra species are found at elevations of 0-1700 m. Most species are lowland forest species, but some may also be components of montane forests, e.g. O. aberrans, O. laurifolia, $O$. longipetala, O. panamensis and $O$. reticulata.

Most of the species are flowering either from February to April or from August to December, but some species flower in the middle of the year; $O$. euneura is noted to flower all year through. Fruiting usually follows 1-2 months later, mostly from January to May or less often from October to December. Some species are mentioned to fruit all year through.

\section{TAXONOMIC TREATMENT}

\section{Oxandra}

Oxandra A.Rich. (1841) 45. — Lecto: Oxandra virgata (Sw.)A.Rich. — Uvaria virgata Sw., nom. illeg = Oxandra lanceolata (Sw.) Baill.

Trees or shrubs $0.5-45 \mathrm{~m}$ tall, 2-70 cm diam; leafy twigs terete, often covered with appressed to erect, simple hairs when young, soon becoming glabrous. Leaves: distichous, simple, entire, shortly petiolate, exstipulate; lamina small to medium-sized, mostly narrowly elliptic to ovate or obovate, leaf index varying from 1.6-10, chartaceous to coriaceous, verruculose or not, shiny or dull above, upper side mostly glabrous, rarely covered with appressed hairs, lower side glabrous or sometimes covered with appressed to erect hairs, base acute, obtuse, to cordate, sometimes with two distinct angular to tooth-like projections on either side, apex acute to acuminate, venation brochidodromous, primary vein impressed, flat or raised above, secondary veins mostly distinct, 6-20 on either side of primary vein, mostly raised, rarely flat or impressed above, angle of secondary veins with primary vein $40-80^{\circ}$, sometimes united into a distinct marginal vein, smallest distance between loops or marginal vein and margin 1-6 $\mathrm{mm}$, tertiary veins flat or raised above, rarely indistinct, reticulate, rarely percurrent. Inflorescences axillary (very rarely extra-axillary), among leaves, 1-several-flowered; (flower/fruiting) pedicels $1-15 \mathrm{~mm}$ long, $0.5-3 \mathrm{~mm}$ diam with several, small, ciliate, mostly depressed ovate bracts. Indument: pedicels, outer side of bracts, and sepals glabrous or sparsely to rather densely covered with appressed hairs, outer side of petals glabrous or sparsely to densely covered with appressed, rarely erect hairs. Flowers actinomorphic, bisexual or rarely male (plant androdioecious), perianth consisting of one whor of sepals and two whorls of petals; flower buds ellipsoid to globose; sepals 3 , imbricate, free (rarely connate), thin, margins often ciliate; petals 6 , imbricate, free, thin, often cream to white, both whorls often equal in length, margins often ciliate; torus depressed ovoid to cylindrical; stamens 5-50, appearing spirally arranged, extrorse, filament very short, apex of connective narrowly triangular, broadly ovate, depressed ovate, rarely quadrangular, glabrous; staminodes absent; carpels few to many, spirally arranged, free, ovary 1-locular with 1 basal ovule, stigma spheroid. Fruit apocarpous, composed of 1-25 indehiscent, fleshy, stipitate monocarps, yellow, orange, pinkish, maroon, bright red to dark purple or black, rarely glaucous in vivo, ellipsoid, ovoid, obovoid to globose, rarely oblongoid, $7-30$ by $4-16 \mathrm{~mm}$, rarely $20-25 \mathrm{~mm}$ diam, mostly glabrous, apex rounded or apiculate (apiculum $0.2-1(-2.5) \mathrm{mm}$ long, wall 0.1-3 $\mathrm{mm}$ thick, stipes $0-16 \mathrm{~mm}$ long; seed 1, basal, hilum circular or transversely elliptic, raphe straight, impressed to raised, not arillate, oblongoid-ellipsoid to globose, cream or pale brown to dark brown or reddish, surface minutely pitted to transversely striate, ruminations spiniform, peg-shaped or lamellate in 4 parts.
Chromosome number $-2 \mathrm{n}=18$ (Morawetz \& Waha 1986 - based on the specimen Morawetz \& Wallnöfer 12-51085, originally identified as $O$. riedeliana, but now reidentified as $O$. polyantha).

Distribution -28 species all over the Neotropics, except for Paraguay and Argentina.

Habitat \& Ecology - In non-inundated or periodically inundated lowland rainforest, dry forests, swamps or savannas. At elevations of sea level up to $1700 \mathrm{~m}$.

\section{KEY TO THE SPECIES}

1. Leaves linear (leaf index 9-10), up to $1.5 \mathrm{~cm}$ wide. - CoIombia (Antioquia) . . . . . . . . . 19. O. rheophytica

1. Leaves not linear, generally wider (leaf index $1.5-5$; to 8 in O. xylopioides) ................... 2

2. Flowers placed opposite the leaves. - Mexico (Chiapas) 1. O. aberrans

2. Flowers placed in the axils of the leaves, or in axils of fallen leaves ................... 3

3. Leaves with a distinct marginal vein . . . . . . . . 4

3. Leaves without a marginal vein . . . . . . . . . . 5

4. Monocarps strongly narrowed and pointed towards the apex; smallest distance between marginal vein of leaves and margin 3-5 $\mathrm{mm}$; flowers produced from leafy branches. - Throughout the Amazon region . . . 5. O. euneura

4. Monocarps rounded at the apex; smallest distance between marginal vein of leaves and margin $5-7 \mathrm{~mm}$; flowers mostly produced from leafless branches. - Brazil (Pará and adjacent Amazonas), Suriname, Peru 7. O. krukoffii

5. Number of bracts $1-2$; leaves $3-10$ by $1-5 \mathrm{~cm}$, tertiary veins distinctly raised above and below, lower side often provided with reddish to black dots . . . . . . . . 6

5. Number of bracts 3 or more (but 2-4 in O. surinamensis); leaves generally larger, tertiary veins not distinctly raised above and below, lower side generally without dots . . 7

6. Base of leaves acute to slightly attenuate; pedicels 10-14 $\mathrm{mm}$ long; stipes 7-8 mm long. - Brazil (Espírito Santo) 25. O. unibracteata

6. Base of leaves cordate to obtuse; pedicels $3-4 \mathrm{~mm}$ long; stipes 1-4 mm long. - Mainly SE and E Brazil . . . . . . .

18. O. reticulata

7. Base of leaves always provided with two distinct teeth or angular projections, venation indistinct . . . . . . 8

7. Base of leaves not or sometimes provided with two teeth or projections, venation mostly distinct . . . . . . 9

8. Monocarps 7-11 mm long, stipes 3-7 mm long; number of secondary veins 7-9; leaf index 2.6-3.1. - Guyana

6. O. guianensis

8. Monocarps 13-25 mm long, stipes 1-4 mm long; number of secondary veins 10-16; leaf index 3.6-8. - Throughout the Amazon region .......... 27. O. xylopioides

9. Primary vein raised to flat on the upper side of the leaves (but see also under O. espintana) . . . . . . . . . 10

9. Primary vein impressed to flat on the upper side of the

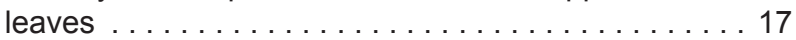

10. Inflorescence up to 12-flowered (examine carefully!) . 11

10. Inflorescence up to 2-flowered (see also O. leucodermis which is rarely up to 6 -flowered) . . . . . . . . 12

11. Leaves chartaceous, primary vein at lower side green, base acute to attenuate; young twigs and lower side of leaves glabrous. - Throughout the Amazon region. . . . . . . . .

11. Leaves coriaceous, primary vein at the lower side reddish brown, base acute to obtuse; young twigs and lower side of 
leaves sparsely covered with appressed hairs. - Throughout the Amazon region and also in the Colombian state of El Valle del Cauca .............. 17. O. polyantha

12. Monocarps $15-30 \mathrm{~mm}$ long ... . . . . . . . . . 13

12. Monocarps $8-15 \mathrm{~mm}$ long $\ldots \ldots \ldots \ldots \ldots \ldots \ldots 14$

13. Monocarps ellipsoid, $15-30$ by $8-14 \mathrm{~mm}$; apex of leaves long-acuminate; flowers produced from leafy branches. - The Guianas, Amazonian Brazil, Colombia and Venezuela . . . . . . . . . . . . . . . . 2. O. asbeckii

13. Monocarps subglobose, $20-25 \mathrm{~mm}$ diam; apex of leaves obtuse to bluntly acute; flowers often produced from leafless branches. - Bolivia (Santa Cruz), Brazil (Bahia, Goiás, Mato Grosso do Sul, Tocantins) . . 21. O. saxicola

14. Petals $12-22 \mathrm{~mm}$ long; leaf base obtuse to slightly cordate, often almost stem-clasping. - Central America, Colombia (Antioquia), Peru (Puno), Brazil (Pará) ... 11. O. longipetala

14. Petals 3-7 mm long; leaf base acute to obtuse, never

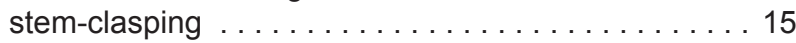

15. Bark often whitish; pedicels $2-15 \mathrm{~mm}$ long. - Throughout the Amazon region . . ........10. O. leucodermis

15. Bark never whitish; pedicels $1-3 \mathrm{~mm}$ long ....... 16

16. Leaves rhombic to ovate or narrowly ovate, $1.5-3.5 \mathrm{~cm}$ wide, rather densely to sparsely verruculose. - Mexico, Greater Antilles, Colombia (San Andrés y Providencia) .

8. O. lanceolata

16. Leaves narrowly elliptic to narrowly obovate, $3-5 \mathrm{~cm}$ wide, not verruculose. - Suriname . . . 24. O. surinamensis

17. Stipes $0-3 \mathrm{~mm}$ long (but see also O. panamensis) .. 18

17. Stipes (except in O. panamensis p.p.) $\geq 3 \mathrm{~mm}$ long, up to $16 \mathrm{~mm}$ long in O. sphaerocarpa . . . . . . . . 22

18. Number of monocarps 4-12; flower buds ellipsoid. - Brazil (Espírito Santo, Minas Gerais, Rio de Janeiro) . . . . . . . .

13. O. martiana

18. Number of monocarps 1-7; flower buds globose . . . 19

19. Monocarps $11-20 \mathrm{~mm}$ long, wall $2-3 \mathrm{~mm}$ thick. - Colombia (Bolívar) . . . . . . . . . . . . 3. O. bolivarensis

19. Monocarps 7-13 mm long, wall $0.2-0.5 \mathrm{~mm}$ thick . . 20

20. Young twigs and petals rather densely covered with appressed hairs; leaf base obtuse to slightly cordate. - SE and $E$ Brazil . . . . . . . . . . 22. O. sessiliflora

20. Young twigs glabrous or sparsely covered with appressed hairs; petals glabrous; leaf base acute . . . . . . . 21

21. Leaves rather densely verruculose, rather densely covered with appressed and erect hairs to glabrous below, apex long-acute to acuminate. - Mexico (Chiapas), Guatemala, Belize .................... 14. O. maya

21. Leaves not or rarely slightly verruculose, glabrous, apex bluntly acute to shortly and bluntly acuminate. - Throughout the Amazon region and SE Brazil ... 4. O. espintana

22. Flower buds globose; lower side of leaves glaucous; monocarps glaucous; ruminations lamellate in 4 parts. - Mexico, Central America, northern South America (Colombia, Venezuela). . . . . . . . . . 26. O. venezuelana

22. Flower buds ellipsoid; lower side of leaves never glaucous; monocarps never glaucous; ruminations composed of spiniform pegs . . . . . . . . . . . . 23

23. Stipes 6-16 mm long; monocarps mostly globose (but see also O. panamensis). - Amazonian Brazil, Ecuador, Peru . . . . . . . . . . . . 23. O. sphaerocarpa

23. Stipes 1-8 mm long; monocarps generally ellipsoid. . 24

24. Leaves large, $17-26$ by $6-12 \mathrm{~cm}$, primary vein at upper side densely covered with erect hairs (to c. $2 \mathrm{~mm}$ long); smallest distance between loops and leaf margin 2-5 mm. - Amazonian Brazil and Peru 12. O. macrophylla
24. Leaves smaller, $7-17$ by $2-6 \mathrm{~cm}$, primary vein glabrous at upper side of leaves; smallest distance between loops and leaf margin $1-3 \mathrm{~mm} \ldots \ldots \ldots \ldots \ldots . \ldots 25$

25. Leaves with distinct secondary venation, not or sparsely verruculose; number of monocarps 2-7. - Greater and Lesser Antilles . . . . . . . . . . . . . 9. O. laurifolia

25. Leaves with indistinct secondary venation, densely to sparsely verruculose; number of monocarps 5-25 . . 26

26. Number of monocarps $7-12$, these $9-15 \mathrm{~mm}$ long, wall 0.3-0.4 mm thick; leaf apex acuminate (acumen 20-30 $\mathrm{mm}$ long). - Throughout the Amazon region . . . . . . .

15. O. mediocris

26. Number of monocarps 5-25, these $12-22 \mathrm{~mm}$ long, wall $0.5-1 \mathrm{~mm}$ thick; leaf apex long-acute to acuminate (acumen 5-15 mm long). - Nicaragua, Panama, Colombia (Antioquia, Bolívar) ........... 16. O. panamensis

1. Oxandra aberrans Maas \& Junikka, sp. nov. - Fig. 3, 4a; Map 1

Ab omnibus speciebus Oxandrae floribus extra-axillaribus, spongosis differt. - Typus: Kennedy \& Breedlove 1422 (holo L), Mexico, Chiapas, km 3 of road from Ocozocoautla to Malpasol, c. $0.6 \mathrm{~km}$ up the stream bed toward hill, 2700 ft, 2 Aug. 1972.

Tree to c. $5 \mathrm{~m}$ tall, diam not recorded; young twigs sparsely covered with appressed hairs, soon glabrous. Leaves: petiole 2-3 mm long, c. $0.5 \mathrm{~mm}$ diam; lamina narrowly elliptic to elliptic, $4-8$ by $1.5-2.5 \mathrm{~cm}$ (leaf index $2.5-3.2$ ), chartaceous, not verruculose, dull and green above, glaucous green below, glabrous above, covered with some appressed hairs mainly along primary vein below, base acute and slightly attenuate, apex bluntly acute, primary vein flat to impressed above, secondary veins distinct, 8-10 on either side of primary vein, raised above, angle of secondary veins with primary vein $60-70^{\circ}$, smallest distance between loops and margin 1-2 mm, tertiary veins slightly raised above, reticulate. Flowers solitary, opposite the leaves; pedicels $3-5 \mathrm{~mm}$ long, c. $1 \mathrm{~mm}$ diam, rather densely covered with appressed hairs; bracts 2 , broadly ovate-triangular, $1-1.5$ by $1-1.5 \mathrm{~mm}$, outer side rather densely covered with appressed hairs; flower buds globose; sepals broadly ovate-triangular, $1.5-2.5$ by $1.5-2.5 \mathrm{~mm}$, outer side rather densely covered with appressed hairs; petals cream to pale green in vivo, 'spongy', $1.5-2.5 \mathrm{~mm}$ thick in vivo, elliptic, c. 8 by $5 \mathrm{~mm}$, outer side rather densely covered with appressed hairs; stamens c. 50, 1.5-2 mm long, apex of connective depressed ovate; carpels c. 15. Monocarps and seed not seen.

Distribution - Mexico (Chiapas).

Habitat \& Ecology — In deciduous forest. At an elevation of c. 900 m. Flowering: August; fruiting: not recorded.

Field observations - Petals thick, spongy, 1.5-2.5 mm thick (Kennedy \& Breedlove 1422).

Note - Oxandra aberrans, only known from the type collection, is unique in the genus by the position of its flowers, which are placed opposite the leaves instead of axillary. Other remarkable features of this species are the low number of bracts (2), and the 'spongy', hairy petals.

\section{Oxandra asbeckii (Pulle) R.E.Fr. - Plate 1a-c; Map 1}

Oxandra asbeckii (Pulle) R.E.Fr. (1931) 167, f. 5a, b. — Bocagea asbeckii Pulle (1909) 262. - Type: Van Asbeck 81 (holo U), Suriname, Patrick Savanne, July 1907.

Tree or shrub 4-25 m tall, 5-25 cm diam; young twigs densely covered with appressed hairs, soon glabrous. Leaves: petiole 2-5 mm long, 1-1.5 mm diam; lamina narrowly elliptic, rarely elliptic, $7-13$ by $3-5 \mathrm{~cm}$ (leaf index $2-3.1$ ), chartaceous, rather 


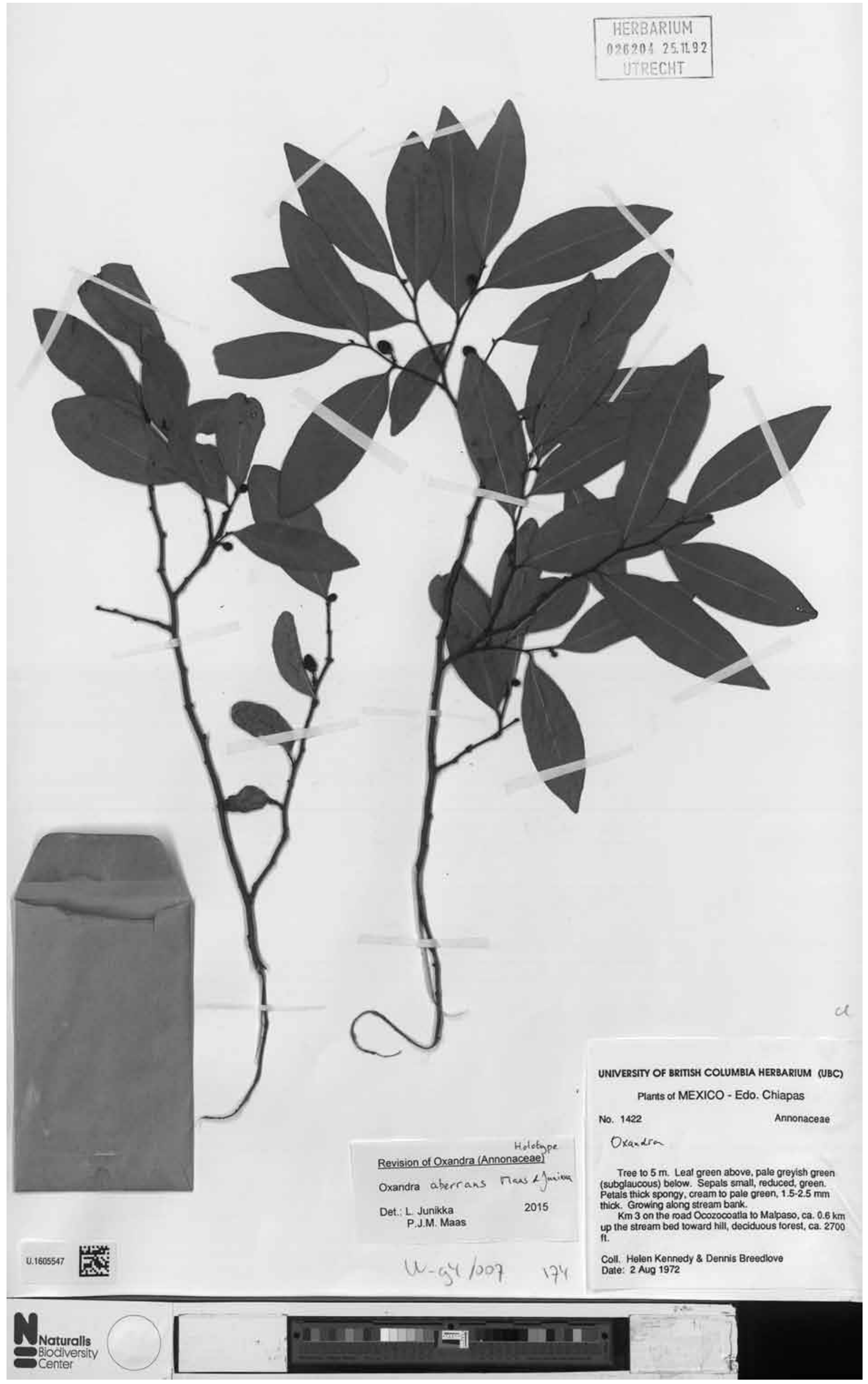

Fig. 3 Oxandra aberrans Maas \& Junikka. Flowering branch (Kennedy \& Breedlove 1422, holo U). 


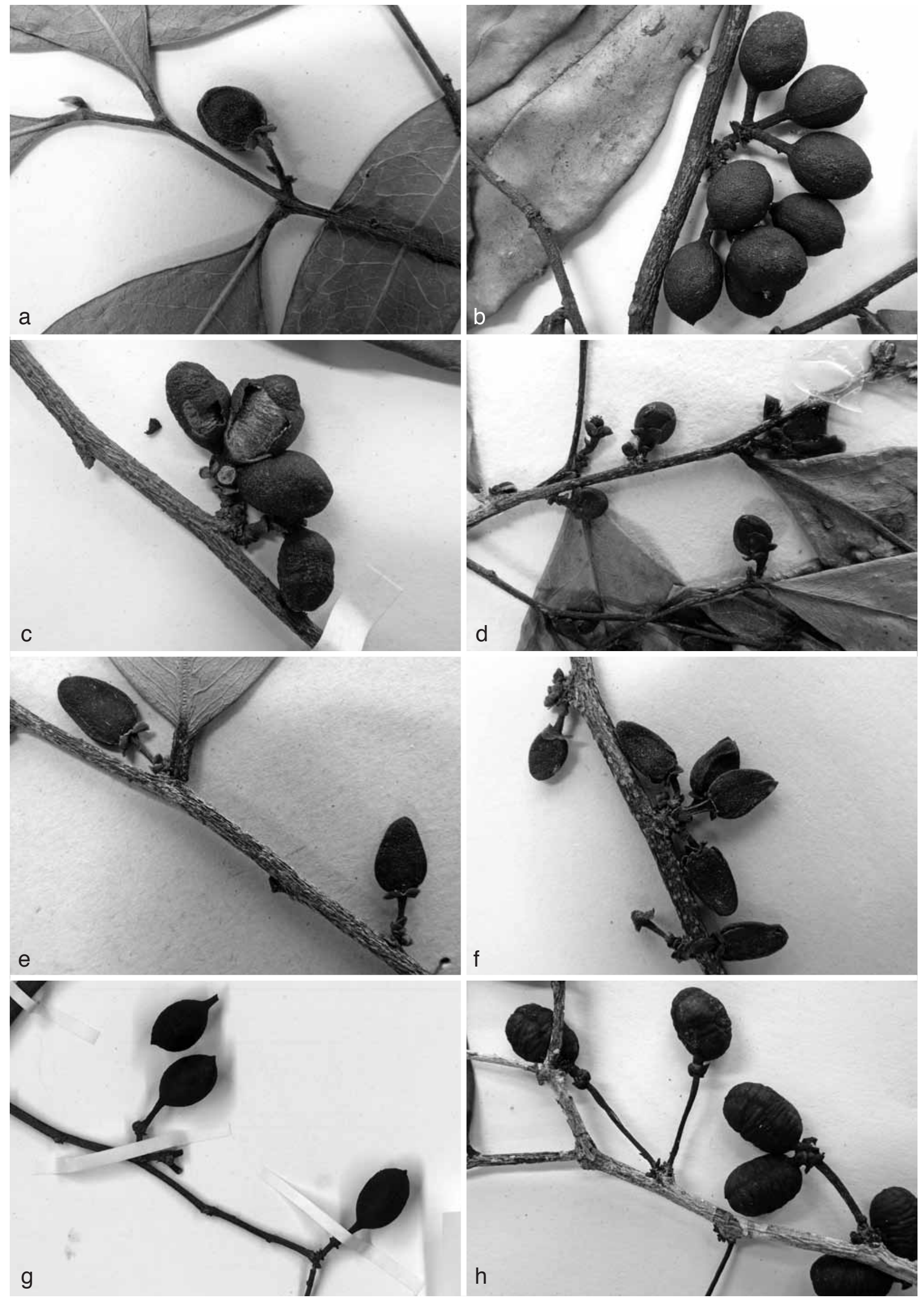

Fig. 4 a. Oxandra aberrans Maas \& Junikka. Detail of flowering branch. - b. Oxandra guianensis R.E.Fr. Detail of fruit. - c. Oxandra krukoffii R.E.Fr. Detail of fruit. - d. Oxandra lanceolata (Sw.) Baill. Detail of flowers. - e-g. Oxandra laurifolia (Sw.) A.Rich. e. Detail of flowers; f. several-flowered inflorescence; g. fruits - h. Oxandra leucodermis (Spruce ex Benth.) Warm. Detail of fruit (a: Kennedy \& Breedlove 1422, holo U; b: Hoffman et al. 1463, U; c: Prance et al. 25831, U; d: Proctor 36333, MO; e: Sintenis 4313, U; f: Wright 4, U; g: Zanoni et al. 33142, U; h: Cid et al. 7302, U). 

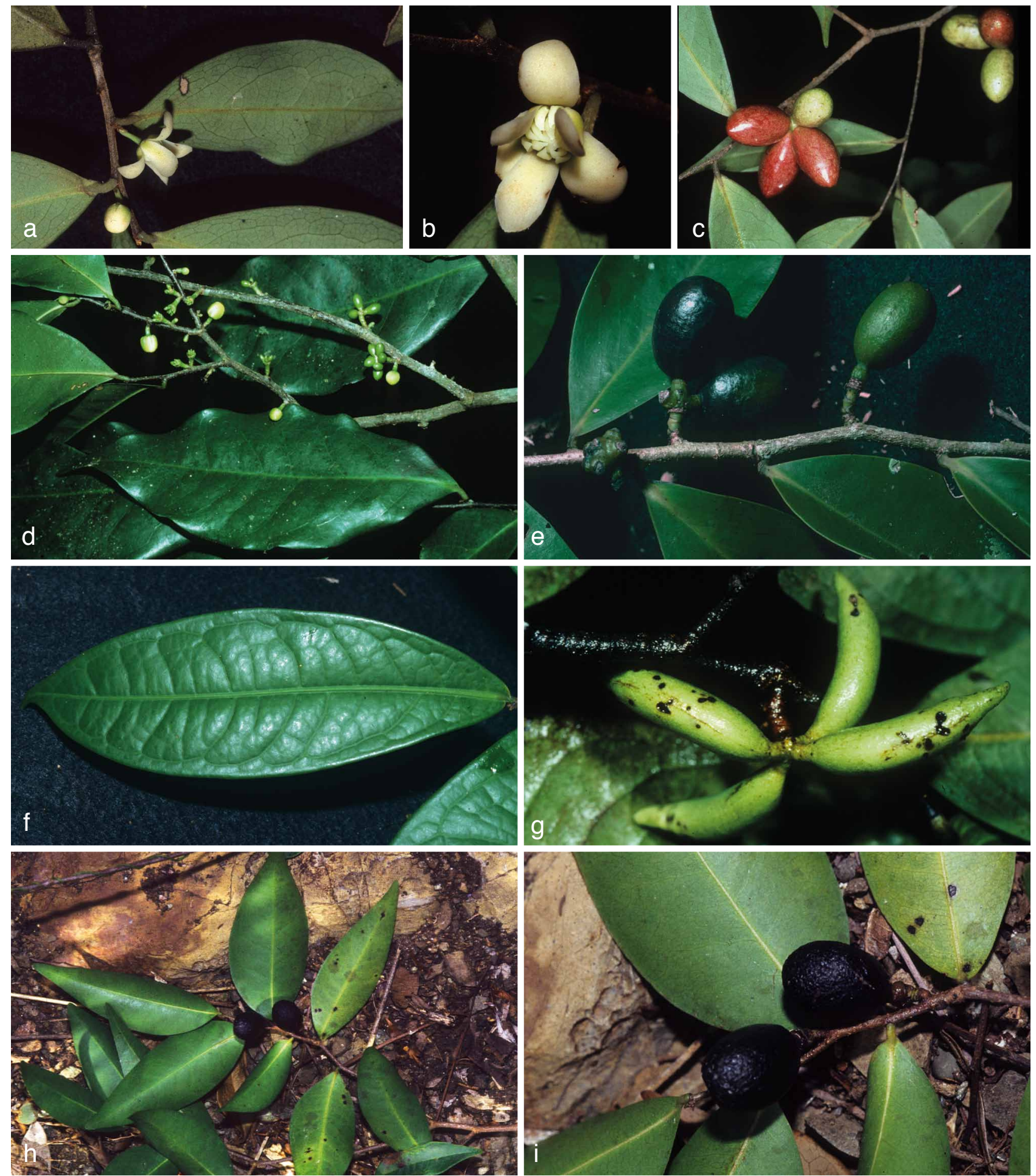

Plate 1 a-c. Oxandra asbeckii (Pulle) R.E.Fr. a. Flowering twig; b. detail of flowering twig; c. fruiting twig. - d-e. Oxandra espintana (Spruce ex Benth.) Baill. d. Flowering twig; e. fruiting twig. - f-g. Oxandra euneura Diels. f. Leaf; g. fruit. - h-i. Oxandra lanceolata (Sw.) Baill. h. Fruiting twig; b. fruits (a, b: Polak et al. 397; c: Mori et al. 22779; d: Foster 11313; e: Maas et al. 5955; f, g: Maas et al. 9226; h, i: Maas 6395). — Photos: a, d. R.B. Foster; b, e-i. P.J.M. Maas; c. S.A. Mori.

densely verruculose mostly below, shiny and greyish green above, grey to brown and often glaucous below, glabrous above, sparsely covered with some appressed hairs along the primary vein below, base acute to attenuate, rarely obtuse, apex long-acuminate (acumen 5-20 mm long), primary vein raised above, secondary veins distinct, 6-7 on either side of primary vein, slightly raised above, angle of secondary veins with primary vein $60-70^{\circ}$, smallest distance between loops and margin $3-5 \mathrm{~mm}$, tertiary veins slightly raised above, reticulate. Flowers solitary; pedicels $1-5 \mathrm{~mm}$ long, $1 \mathrm{~mm}$ diam, fruiting pedicels 3-7 $\mathrm{mm}$ long, 1-2 $\mathrm{mm}$ diam, sparsely covered with appressed hairs; bracts $3-7$, depressed ovate, $1-1.5 \mathrm{~mm}$ long, outer side rather densely covered with appressed hairs; flower buds subglobose to ellipsoid; sepals broadly ovate, $1.5-2$ by 1.5-2 mm, outer side sparsely covered with appressed hairs to glabrous; petals white in vivo, ovate, $6-9$ by $3-4 \mathrm{~mm}$, outer side glabrous; stamens 9-12, 3-3.5 mm long, apex of connective narrowly triangular; carpels $\leq 7$. Monocarps $1-7$, green, maturing purple to finally dark purple to black in vivo, black in sicco, ellipsoid, $15-30$ by $8-14 \mathrm{~mm}$, glabrous, apex apiculate (apiculum to c. $1 \mathrm{~mm}$ long), wall $0.5-1 \mathrm{~mm}$ thick, stipes $1-2$ by 1-2 mm. Seed ellipsoid, $15-20$ by $8-10 \mathrm{~mm}$, brown, surface minutely pitted to transversely striate, ruminations spiniform or peg-shaped. 
Distribution - Colombia (Amazonas), Venezuela (Amazonas), Guyana, Suriname, French Guiana, Brazil (Acre, Amazonas).

Habitat \& Ecology — In non-inundated rainforest, Wallaba forest, low caatinga forest, campinarana (with a layer of litter and humus $10-30 \mathrm{~cm}$ deep), or rarely inundated forest, on brown sands, white sands or on lateritic soil. At elevations of $0-800 \mathrm{~m}$. Flowering: April, May, November; fruiting: July to March.

Vernacular names - Colombia: Cajao-dujeco (Muinane name, Urrego G. et al. 643), Carguero de vara (Mohr \& Sosa 49). French Guiana: Aso mato, Bi pao, Gie pawoe (Saramaca name, Mori et al. 23388), Mi-Pente, Moemba, Mouamba (Paramaca name, Mori et al. 23388), Bamba (Saramaca name, Villiers 5255bis), Moemba (Boni name, Fleury 161, 830), Mwemba (Boni name, Fleury 347), Npomba (Djuka name, Sauvain 451). Guyana: Karashiri (Arawak name, FDBG 2727, 3789, 4836), Karishiri (Arawak name, Ek 833, Persaud 339, 343, University of Guyana, Course Neotropical Botany 55). Suriname: Echte pikapika (Surinamese Dutch name, Schulz LBB 7667), Foedida (Stahel, Woodherbarium Suriname 271), Hansoe matoe (Saramaca name, Van Donselaar 3499), Mamba (Aucan name, Van Donselaar 1024), Mwamba (Aucan name, Van Donselaar 3499), Pikapika (Sranang name, Van Donselaar 1024, 3499, Lanjouw \& Lindeman 2165, Lindeman 6988, Schulz LBB 8050 , Van Andel 4639), Schopsteelenhout (Surinamese Dutch name, Van Asbeck BBS 81).

Uses - Used for making 'carbets' and 'takari' poles (Mori et al. 23388, French Guiana).

Field observations - Mature fruit with taste somewhat like that of date (Maas et al. 7738, Guyana); Les toucans son friands de ces fruits dont on trouve les grains à terre (Prévost 278, French Guiana).

Note - Oxandra asbeckii is quite characteristic by its leaf venation, which is raised on both sides and by its relatively small, long-acuminate leaves. Material from the Guianas has verruculose leaves, Brazilian, Colombian and Venezuelan collections have non-verruculose leaves. As all other features of leaves and fruits fell nicely in the concept of $O$. asbeckii we have refrained from naming it.

\section{Oxandra bolivarensis Maas \& Junikka, sp. nov. - Fig. 5;} Map 1

Foliis anguste ovatis, apice acutis, floribus breviter pedicellatis, monocarpiisque pro ratione paucis facile recognoscenda. - Typus: Forero \& Jaramillo 493 (holo MO; iso NY), Colombia, Bolívar, Morales, Cerros rocosos calcáreos, 80 m, 22 Apr. 1966
Tree 3-7 m tall, c. $12 \mathrm{~cm}$ diam; young twigs slightly grooved, densely covered with erect hairs $<0.1 \mathrm{~mm}$ long, soon glabrous. Leaves: petiole 2-3 mm long, $0.5-1 \mathrm{~mm}$ diam; lamina narrowly ovate, $7-10$ by $2.5-3 \mathrm{~cm}$ (leaf index $3-3.6$ ), chartaceous, not verruculose, shiny and dark brown to blackish brown above, brown below, glabrous above, rather densely covered with appressed hairs, but very soon glabrous below, base obtuse, apex acute, primary vein impressed to flat above, secondary veins distinct, 8-10 on either side of primary vein, raised above, angle of secondary veins with primary vein $50-60^{\circ}$, smallest distance between loops and margin c. $2 \mathrm{~mm}$, tertiary veins raised above, reticulate. Flowers in 1-2-flowered inflorescences; flowering pedicels 1-2 mm long, c. $1 \mathrm{~mm}$ diam, fruiting pedicels $2-4 \mathrm{~mm}$ long, 1-2 mm diam, glabrous; bracts 5-7, depressed ovate, c. 1 by $1.5 \mathrm{~mm}$, outer side sparsely covered with appressed hairs to glabrous; flower buds globose; sepals shallowly ovatetriangular, $1-2$ by $1.5-2 \mathrm{~mm}$, outer side glabrous; petals creamy white, elliptic, $4-7$ by $3-4 \mathrm{~mm}$, outer side glabrous; stamens $\mathrm{c}$. $25,1.5-2 \mathrm{~mm}$ long, apex of connective narrowly triangular to depressed ovate; carpels $\leq 3$. Monocarps $1-3$, green, maturing black in vivo, black in sicco, globose, $11-20$ by $11-20 \mathrm{~mm}$, glabrous, apex rounded, wall 2-3 mm thick, stipes absent. Seed globose, $10-20$ by $10 \mathrm{~mm}$, brown, surface minutely pitted, ruminations spiniform.

Distribution - Colombia (Bolívar)

Habitat \& Ecology — In disturbed moist forest. At elevations of 200-250 m. Flowering: April, September; fruiting: January, April, September.

Other specimens examined. ColomBIA, Bolívar, Mun. San Juan de Nepomuceno, Loma de los Colorados, 200 m, Cuadros V. 3155 (MO, NY, U); Santuario Nacional de los Colorados, Mun. San Juan Nepomuceno, 70 km SW of Cartagena, 230-250 m, Gentry et al. 60575 (MO, U).

Note - Oxandra bolivarensis is characterized by narrowly ovate, shiny and acute-tipped leaves, short pedicels, and few (1-3), globose monocarps. The monocarps of $O$. bolivarensis have an extremely thick wall for a species of Oxandra.

4. Oxandra espintana (Spruce ex Benth.) Baill. — Fig. 1; Plate $1 \mathrm{~d}-\mathrm{e}$; Map 2

Oxandra espintana (Spruce ex Benth.) Baill. (1868a) 207. - Bocagea espintana Spruce ex Benth. (1860) 71. - Type: Spruce 4920 (holo K; iso B, BM, BP, BR, C, E, F, G, GOET, K, MPU, OXF, P, W), Peru, San Martín, near Tarapoto, along Río Huallaga, Nov. 1856.

Oxandra aromatica Triana \& Planch. (1862) 36. - Bocagea aromatica (Triana \& Planch.) Britton (1889) 14. - Type: Triana s.n. (holo P; iso B, BM, G, K 2 sheets, NY, P, W), Colombia, Cundinamarca, between Anapoima and Piedras, valley of Río Magdalena, 500-700 m, anno 1866.

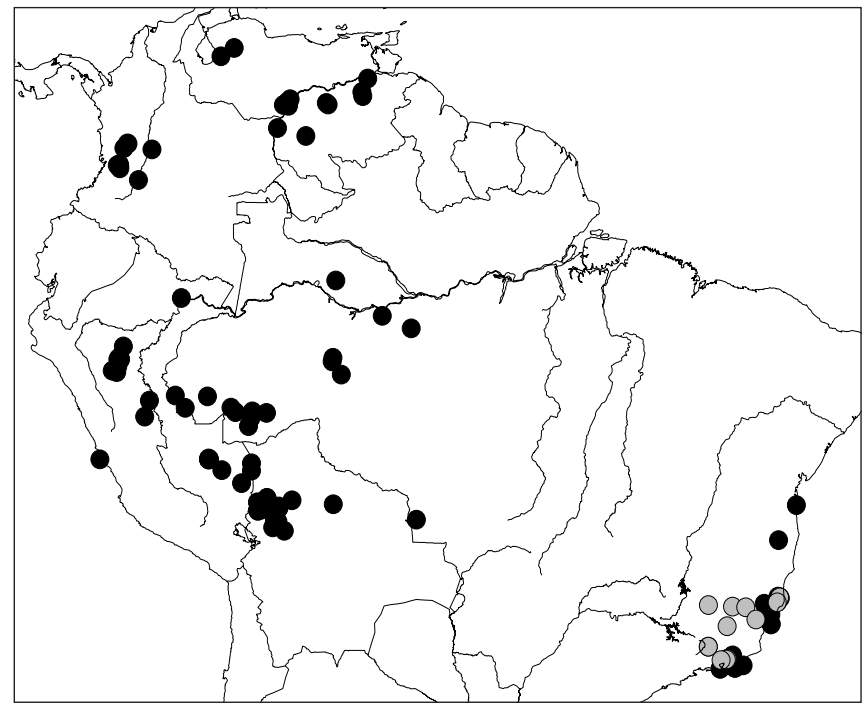

Map 2 Distribution of Oxandra espintana (๑) and O. martiana (○).
Map 1 Distribution of Oxandra aberrans (๑), O. asbeckii (○) and O. boli- varensis $(\mathbf{\Delta})$.

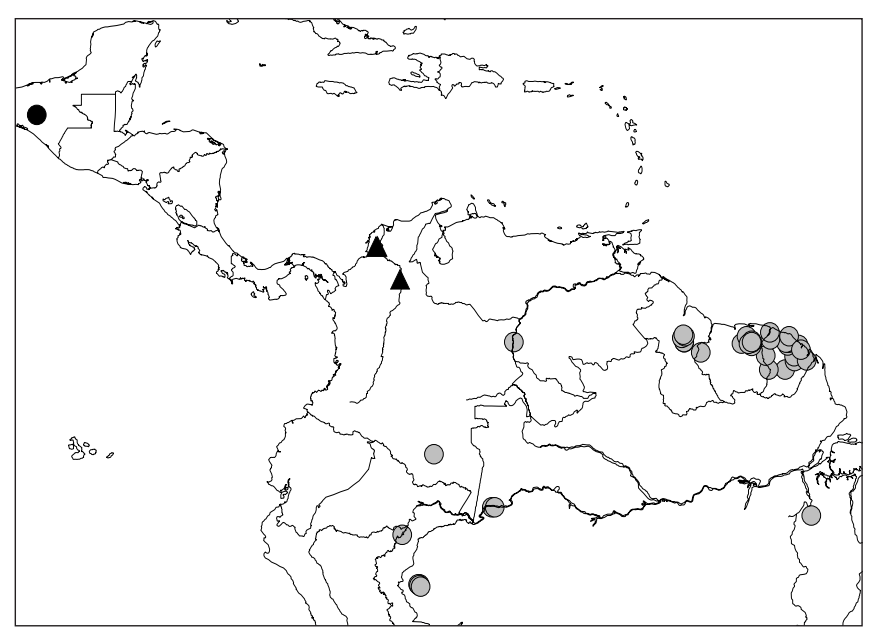




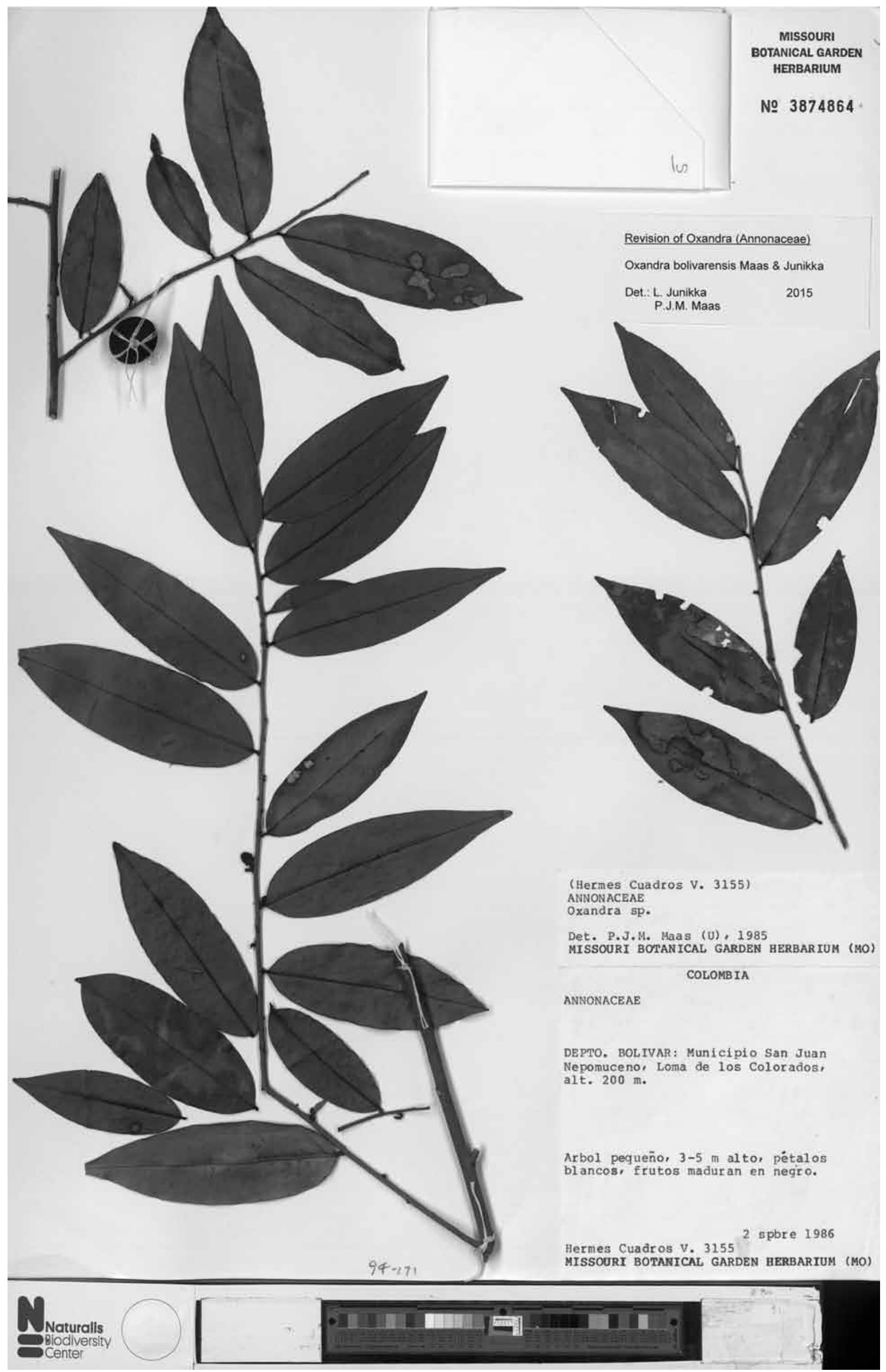

Fig. 5 Oxandra bolivarensis Maas \& Junikka. Flowering and fruiting branch. (Cuadros V. 3155, MO). 
Oxandra ovata Rusby (1920) 19. - Type: R.S. Williams 217 (holo NY; iso NY), Bolivia, La Paz, Prov. Franz Tamayo, Lower Río Cocos, 700-800 m, 25 Mar. 1902.

Oxandra nitida R.E.Fr. (1931) 160, f. 4c, syn. nov. - Type: Riedel s.n. (holo S; iso K, LE), Brazil, Rio de Janeiro, 'in Wäldern bei Mandiocca', Jan. 1824 Oxandra opaca E.Pereira \& Pabst (1977) 210, syn. nov. - Type: Pereira 7254 (holo HB; iso K, M, MBM, NY, US), Brazil, Rio de Janeiro, Rio de Janeiro, 'matas do Jardim Botânico', 15 Feb. 1963.

Oxandra sp. A Steyerm. in Steyermark et al. (1995) 454

Tree or shrub 2-30 m tall, 5-60 cm diam; young twigs glabrous, rarely covered with some appressed (to erect) hairs in the youngest stage. Leaves: petiole 1-3 mm long, c. $1 \mathrm{~mm}$ diam; lamina ovate to obovate to narrowly so, often more or less rhombic, $5-14$ by $1.5-7 \mathrm{~cm}$ (leaf index $2-3.4$ ), chartaceous to coriaceous, not verruculose or rarely slightly verruculose above and below, shiny and greyish to greyish brown above, greyish brown, greenish brown, or pale brown below, glabrous above and below, base acute, apex bluntly acute to shortly and bluntly acuminate (acumen to c. $10 \mathrm{~mm}$ long), primary vein slightly impressed to slightly raised, secondary veins distinct, 6-12 on either side of primary vein, raised above, angle of secondary veins with primary vein $45-65^{\circ}$, smallest distance between loops and margin $1-3 \mathrm{~mm}$, tertiary veins raised above, reticulate. Flowers in 1-2(-3)-flowered inflorescences; pedicels 1-2 $\mathrm{mm}$ long, $0.5-1 \mathrm{~mm}$ diam, 3-6 mm long in fruit, glabrous; bracts 4-10, depressed ovate, $0.5-1.5 \mathrm{~mm}$ long, outer side glabrous, rarely sparsely covered with appressed hairs; flower buds globose; sepals broadly to shallowly ovate-triangular, $0.5-2.5$ by $0.5-3 \mathrm{~mm}$, outer side glabrous, rarely sparsely covered with appressed hairs; petals white to yellow in vivo, ovate to obovate, $5-8$ by $2-5 \mathrm{~mm}$, outer side glabrous; stamens $10-20$, 1-2 mm long, apex of connective narrowly triangular; carpels $\leq 6$. Monocarps 1-6, green, maturing orange-red to dark red and finally black in vivo, black in sicco, ellipsoid, obovoid, or globose, $7-13\{-17\}$ by $5-10\{-12\} \mathrm{mm}$, glabrous, apex rounded, wall $0.2-0.5\{-1.5\} \mathrm{mm}$ thick, stipes $1-1.5$ by $1.5-2 \mathrm{~mm}$ (values between accolades \{\} refer to measurements on material in spirit). Seed ellipsoid, 7-12 by $5-8 \mathrm{~mm}$, pale brown, surface transversely striate, ruminations spiniform, composed of flattened pegs, or lamellate.

Distribution - Colombia (Boyacá, El Valle del Cauca, Huila, Risaralda), Venezuela (Amazonas, Apure, Bolívar, Lara, Trujillo, Zulia), Brazil (Acre, Amazonas, Bahia, Espírito Santo, Minas Gerais, Rio de Janeiro), Peru (Huánuco, Loreto, Madre de Dios, San Martín), Bolivia (Beni, La Paz).

Habitat \& Ecology - Mostly in non-inundated (terra firme) forest, on clayey to sandy soil. At elevations of 0-1070 m. Flowering: all year through; fruiting: all year through.

Vernacular names - Bolivia: Juruqui (Tacana name, DeWalt et al. 226), Palo remo (Rerts 351), Rimo (Fournet 481), Sipico yejperi (Hinojosa 1168), Sipicu (Meneces \& Terceiros 129), Sipiku negro (DeWalt et al. 226), Piraquina negro (DeWalt et al. 226). Brazil: Araticum-do-mato (Folli 2672), Chaporoasca (Daly et al. 7729), Envira-ferro (Daly et al. 11217, Silveira et al. 973, Sothers et al. 52), Envireira-caniceira (Luize 154), Imbiú-amarelo (Kurtz et al. s.n.), Pindaíba-ferreira (Folli 3754). Colombia: Guácano (Silverstone-Sopkin \& Giraldo-Gensini 6167, 6175). Peru: Ayacbara (Schunke V. 2344), Chicoga narangal (Mathias 3931), Espintana (Albán C. 3603, 5915A, Maas et al. 5955, 5956, Reynel 227, J. Ríos 3, Spruce 4920), Espintana blanca (Albán C. 4109), Espintana hoja chiquita (Schunke V. 9784), Espintana negro (Albán C. 5042). Venezuela: Anoncillo (Huber \& Canales 406/16), Majagua (Huber \& Canales 394/1, LI.Williams 13040, 15559), Yadayada (Yekwana name, KnabVispo et al. 676).

Uses - Bark cooked in water for one hour and used for rheumatism (Mathias 3931, Peru); fruit edible (Rusby 47, Bolivia); madera para construcción y muebles (Silverstone-Sopkin 6175, Colombia).
Field observations - Flowers with sweet scent (Maas et al. 8821, Brazil); Flor tiene olor fuerte placentero (SilverstoneSopkin et al. 6167, 6175, 6274, 6314, 6337, Colombia); Flores visitadas por cucarrones (beetles) (Silverstone-Sopkin \& Arroyo V. 6274, Colombia); Flores visitadas por cucarrón pequeño negro (Silverstone-Sopkin \& Arroyo V. 6314, Colombia).

Notes - Oxandra espintana looks somewhat similar to $O$. riedeliana, which differs, however, by a many-flowered inflorescence, larger fruits and seeds, and a thicker fruit wall.

The following Venezuelan collections fall into the concept of O. espintana, but differ by an indument of erect hairs on the youngest twigs or some also with erect hairs on the lower side of young leaves (particularly the primary vein) in addition: $V_{E N}$ EZUelA, Amazonas, El Bagre, near Puerto Ayacucho, $100 \mathrm{~m}$, LI.Williams 13040 (F). Bolívar, Mun. Piar, isla en el lago de Guri, 270 m, Aymard C. \& Norconk 9409 (MO); idem, Aymard C. et al. 10241 (MO); Altoplanice de Nuria, SE of Campamento Nuria, Steyermark 86539 (NY).

Fries (1931) considered O. nitida as a distinct species: "The abundant material of Oxandra now available appears to indicate that we have to do with a new species (O. nitida) which, though related to $O$. espintana, is well distinct by narrower, oblanceolate leaves which gradually narrow towards the base" (translated from German). As we found all kind of intermediate forms between these leaf bases we finally decided to unite both species. For differences with $O$. martiana see the notes under that species.

\section{Oxandra euneura Diels — Plate 1f, g; Map 3}

Oxandra euneura Diels (1927) 173. - Type: Tessmann 5320 (holo B), Peru, Loreto, 'Oberes Amazonas-Gebiet', Lower Río Itaya, Soledad, 110 m, June 1925.

Tree or shrub 2-15 m tall, 3-40 cm diam; young twigs rather densely covered with appressed or erect hairs, soon glabrous. Leaves: petiole 1-5 $\mathrm{mm}$ long, $2-3 \mathrm{~mm}$ diam; lamina narrowly ovate to narrowly obovate, $10-24$ by $3-9 \mathrm{~cm}$ (leaf index 2.5-3.7), chartaceous, densely verruculose above and below, shiny and greyish or brownish green above, brownish green below, glabrous above, sparsely covered with appressed hairs to glabrous below, base acute, obtuse, to oblique and slightly cordate, apex acuminate (acumen 10-20 mm long), primary vein raised above, secondary veins distinct, 10-14 on either side of primary vein, raised above, but seemingly impressed due to the laminar tissue bulging upward, angle of secondary veins with primary vein $65-80^{\circ}$, united into a distinct marginal

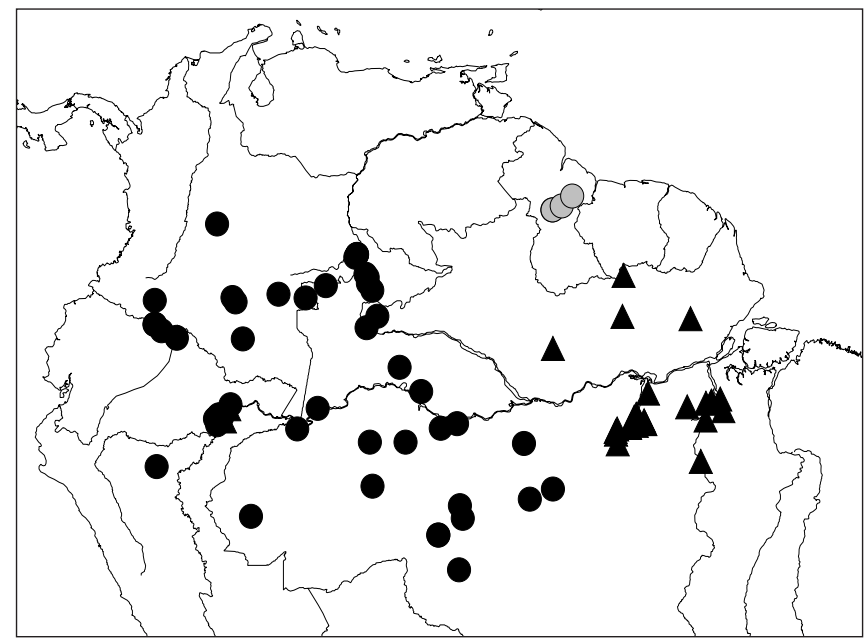

Map 3 Distribution of Oxandra euneura (๑), O. guianensis $(\bigcirc)$ and O. krukoffii (A). 


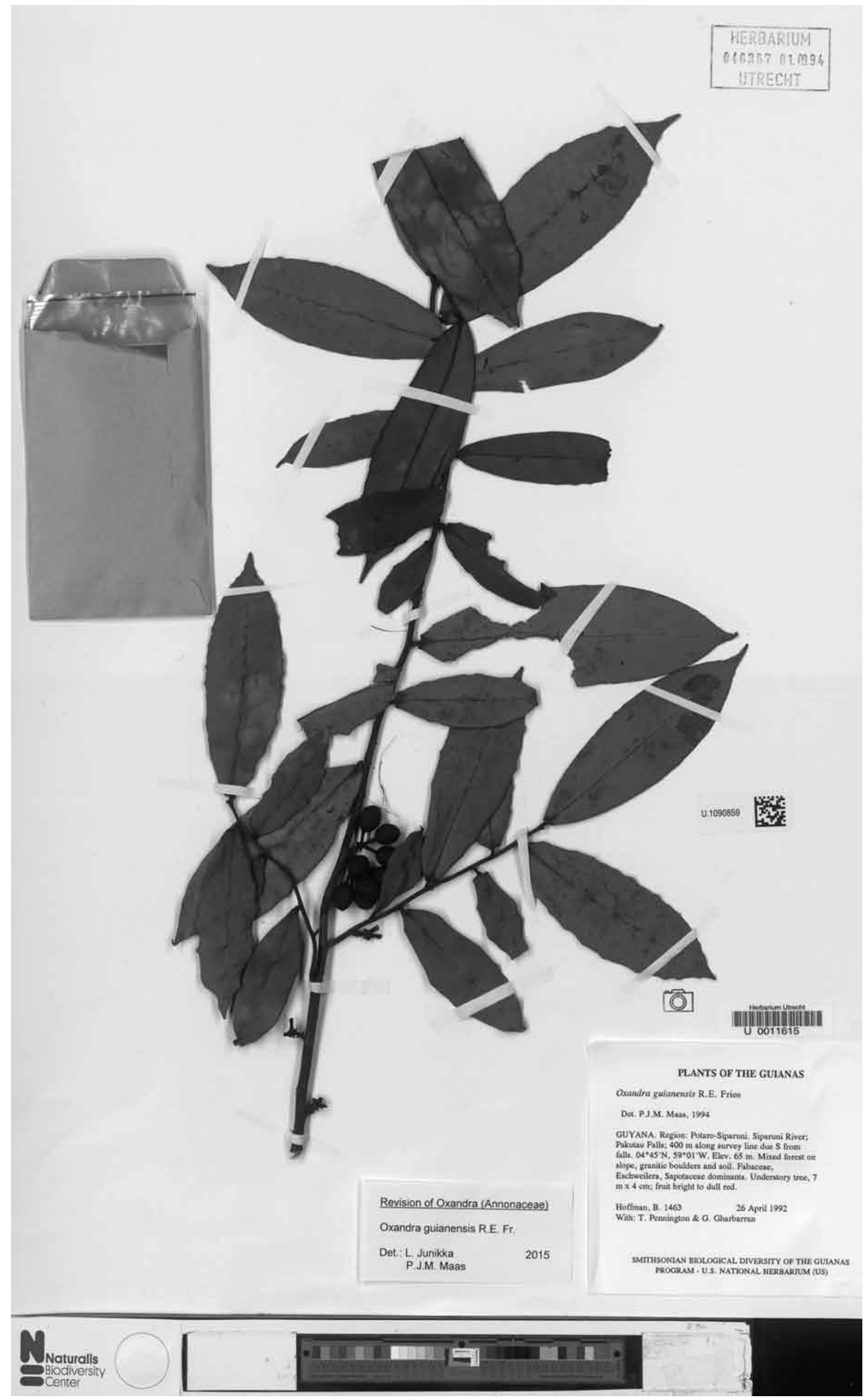

Fig. 6 Oxandra guianensis R.E.Fr. a. Fruiting twig (Hoffman et al. 1463, U). 
vein, smallest distance between marginal vein and margin $3-5 \mathrm{~mm}$, tertiary veins slightly raised above, reticulate. Flowers in 1-2(-4)-flowered inflorescences; pedicels 3-4 mm long, $0.5-1 \mathrm{~mm}$ diam, $4-8 \mathrm{~mm}$ long in fruit, rather densely to sparsely covered with appressed hairs; bracts $3-5$, depressed ovate, $0.5-1.5 \mathrm{~mm}$ long, outer side rather densely to sparsely covered with appressed hairs; flower buds ellipsoid to ellipsoidoblongoid; sepals broadly to shallowly ovate-triangular, 1-1.5 by $1-2 \mathrm{~mm}$, outer side rather densely covered with appressed hairs; petals white in vivo, elliptic to narrowly so, $6-8$ by $2-3$ $\mathrm{mm}$, outer side rather densely covered with appressed and erect hairs; stamens $6-15,2-3 \mathrm{~mm}$ long, apex of connective narrowly triangular; carpels $\leq 6$. Monocarps $1-6$, green, maturing pinkish red to black in vivo, black in sicco, ellipsoid to narrowly ovoid-oblongoid, strongly narrowed towards the apex, sometimes more or less curved, $10-30$ by $6-10 \mathrm{~mm}$, rather densely to sparsely covered with appressed hairs to glabrous, apex apiculate (apiculum 2-2.5 mm long) and often hard-pointed, wall $0.2-0.3 \mathrm{~mm}$ thick, stipes c. 1 by $1-1.5 \mathrm{~mm}$. Seed narrowly oblongoid-ellipsoid, $10-30$ by $6-9 \mathrm{~mm}$, pale brown, surface transversely striate, ruminations spiniform or peg-shaped.

Distribution - Colombia (Amazonas, Caquetá, Vaupés), Venezuela (Amazonas), Ecuador (Napo, Sucumbios), Peru (Loreto), Brazil (Amazonas, Rondônia), Bolivia (La Paz).

Habitat \& Ecology — In periodically inundated (igapó, tahuampa) forests or non-inundated forest, on sandy or clayey soil. At elevations of 0-1000 m. Flowering: all year through; fruiting: all year through.

Vernacular names - Brazil: Pindaípixuna (W. Rodrigues 1006). Colombia: Cueronegro (Wijninga \& Quintero 623), Ficicu (Muinane name, Van Andel 441), Jajobahi hãrãdo jeicobu (= Fishing rod flower, Cubeo name, Madriñán et al. 1182). Peru: Baracaspi (Rimachi Y. 7480), Carahuasca (Vásquez \& Criollo 5786), Espintana (Ellenberg 2907), Espintana amarilla (Dodson \& Torres 2973), Tortuga caspi (Ellenberg 2856), Yahuarachi caspi (Vásquez et al. 5390, 7994), Yana tortuga (McDaniel \& Rimachi Y. 20295).

Uses - Stems used as fishing rods (Madriñán et al. 1182, Colombia); Con el tronco se elaboran varas para pescar, cabos para hachas y palos para bailes ceremonials (Colombia: Sánchez Sáenz 1997).

Field observations - Flores visitadas por Stafilinidios (Knob et al. 1201, Brazil); Corolla with sweet scent (Maas et al. 8234, Peru).

Note - Oxandra euneura is characterized by having a distinct marginal vein and in having quite elongate and often hardpointed, sometimes curved monocarps of $10-30 \mathrm{~mm}$ long.

\section{Oxandra guianensis R.E.Fr. - Fig. 4b, 6; Map 3}

Oxandra guianensis R.E.Fr. (1948) 229. — Type: Forest Department British Guiana (FDBG) 3124 = Fanshawe 388 (holo K; iso FDG, S), Guyana, Big Winiperu Creek, Demarara River, 4 Mar. 1940.

Tree 5-15 m tall, 4-12 cm diam; young twigs densely covered with appressed hairs, soon glabrous. Leaves: petiole $2-5 \mathrm{~mm}$ long, c. $1 \mathrm{~mm}$ diam; lamina narrowly elliptic to narrowly obovate, $8-13$ by $2.5-5 \mathrm{~cm}$ (leaf index 2.6-3.1), coriaceous, densely verruculose above and below, verruculae string-forming particularly below, brown to greyish brown above, brown below, glabrous above, margins and primary vein rather densely covered with appressed, white, hairs when young below, soon glabrous, base acute, with two distinct angular to tooth-like projections on either side, apex shortly acuminate (acumen to c. $5 \mathrm{~mm}$ long), primary vein impressed above, secondary veins indistinct and almost invisible, 7-9 on either side of primary vein, impressed above, angle of secondary veins with primary vein $70-75^{\circ}$, smallest distance between loops and margin 3-5 mm, tertiary veins indistinct and almost invisible, reticulate. Infructescence 1-3-flowered; fruiting pedicels 3-5 mm long, 1-2 mm diam, glabrous; bracts 5-7, depressed ovate, 1-2 mm long, outer side glabrous; flower buds not seen; sepals broadly ovate, $1.5-2$ by 1.5-2 mm, outer side glabrous; petals, stamens and carpels not seen. Monocarps 3-8, bright to dull red in vivo, black in sicco, globose to ellipsoid, $7-11$ by $5-8 \mathrm{~mm}$, glabrous, apex rounded to apiculate (apiculum $<1 \mathrm{~mm}$ long), wall c. $0.5 \mathrm{~mm}$ thick, stipes $3-7$ by $1 \mathrm{~mm}$. Seed ellipsoid, $7-8$ by $5-6 \mathrm{~mm}$, brown, surface transversely striate, ruminations spiniform.

Distribution - Guyana.

Habitat \& Ecology — In non-inundated forest, in the Mabura Hill region with many species of Myrtaceae, on lateritic soil. At elevations of 0-65 m. Flowering: unknown; fruiting: March, April.

Vernacular name - Guyana: Arara (Forest Department British Guiana 3124 = Fanshawe 388).

Note - Oxandra guianensis is restricted to Guyana. It is characterized by leaves which are densely verruculose on both sides and which have a very indistinct venation. Moreover, the leaf base has two distinct angular to tooth-like projections on either side. It is probably closest to 0 . xylopioides, differing by much smaller monocarps (7-11 $\mathrm{mm}$ vs $13-25 \mathrm{~mm}$ long).

\section{Oxandra krukoffii R.E.Fr. - Fig. 4c, 7; Map 3}

Oxandra krukoffii R.E.Fr. (1934) 199. - Type: Krukoff 1124 (holo S; iso B, BM, G, K, NY, P), Brazil, Pará, Upper Cupary River, plateau between the Xingu and Tapajós Rivers, 14 Sept. 1931.

Tree or shrub 3-15 m tall, 5-25 cm diam; young twigs rather densely covered with appressed hairs, soon glabrous. Leaves: petiole 2-5 $\mathrm{mm}$ long, 1-2 $\mathrm{mm}$ diam; lamina narrowly elliptic to narrowly ovate, $10-20$ by $4-7 \mathrm{~cm}$ (leaf index $2.4-3.1$ ), chartaceous, sparsely to rather densely verruculose above, or not verruculose, shiny and greyish green above, greyish green to brownish below, glabrous above, sparsely covered with appressed hairs below, soon glabrous, base obtuse, apex acuminate (acumen 10-15 mm long), primary vein raised above, secondary veins distinct, 10-13 on either side of primary vein, raised above, but often seemingly impressed due to the laminar tissue bulging upward, angle of secondary veins with primary vein $45-80^{\circ}$, united into a marginal vein, smallest distance between marginal vein and margin $5-7 \mathrm{~mm}$, tertiary veins slightly raised above, reticulate. Flowers in 1-3-flowered inflorescences, mostly produced from leafless branches; pedicels $2-5 \mathrm{~mm}$ long, $1-1.5 \mathrm{~mm}$ diam, fruiting pedicels $3-7$ $\mathrm{mm}$ long, 1-2 mm diam, densely to sparsely covered with appressed hairs to glabrous; bracts $4-5$, depressed ovate, $1-3 \mathrm{~mm}$ long, outer side densely to rather densely covered with appressed hairs; flower buds ellipsoid to globose; sepals broadly to shallowly ovate-triangular, $2-3$ by $2-3 \mathrm{~mm}$, outer side densely to rather densely covered with appressed hairs; petals cream to white in vivo, obovate, linear, or elliptic, $8-11$ by $3-6 \mathrm{~mm}$, outer side rather densely covered with appressed hairs; stamens c. 25, 3-4 mm long, apex of connective narrowly triangular; carpels $\leq 10$. Monocarps 1-6, green, maturing red to black in vivo, black, sometimes brown in sicco, ellipsoid, $10-16$ by $6-11$ $\mathrm{mm}$, glabrous, apex rounded, wall $0.2-0.5 \mathrm{~mm}$ thick, stipes $0.5-1$ by $1-2 \mathrm{~mm}$. Seed ellipsoid, $10-15$ by $6-11 \mathrm{~mm}$, pale brown, surface transversely striate, spiniform or composed of flattened pegs.

Distribution - Suriname, Peru (Loreto), Brazil (Pará and adjacent Amazonas).

Habitat \& Ecology — In non-inundated forest, on sandy or clayey soil. At elevations of 0-325 m. Flowering: August, September, November; fruiting: November to March. 


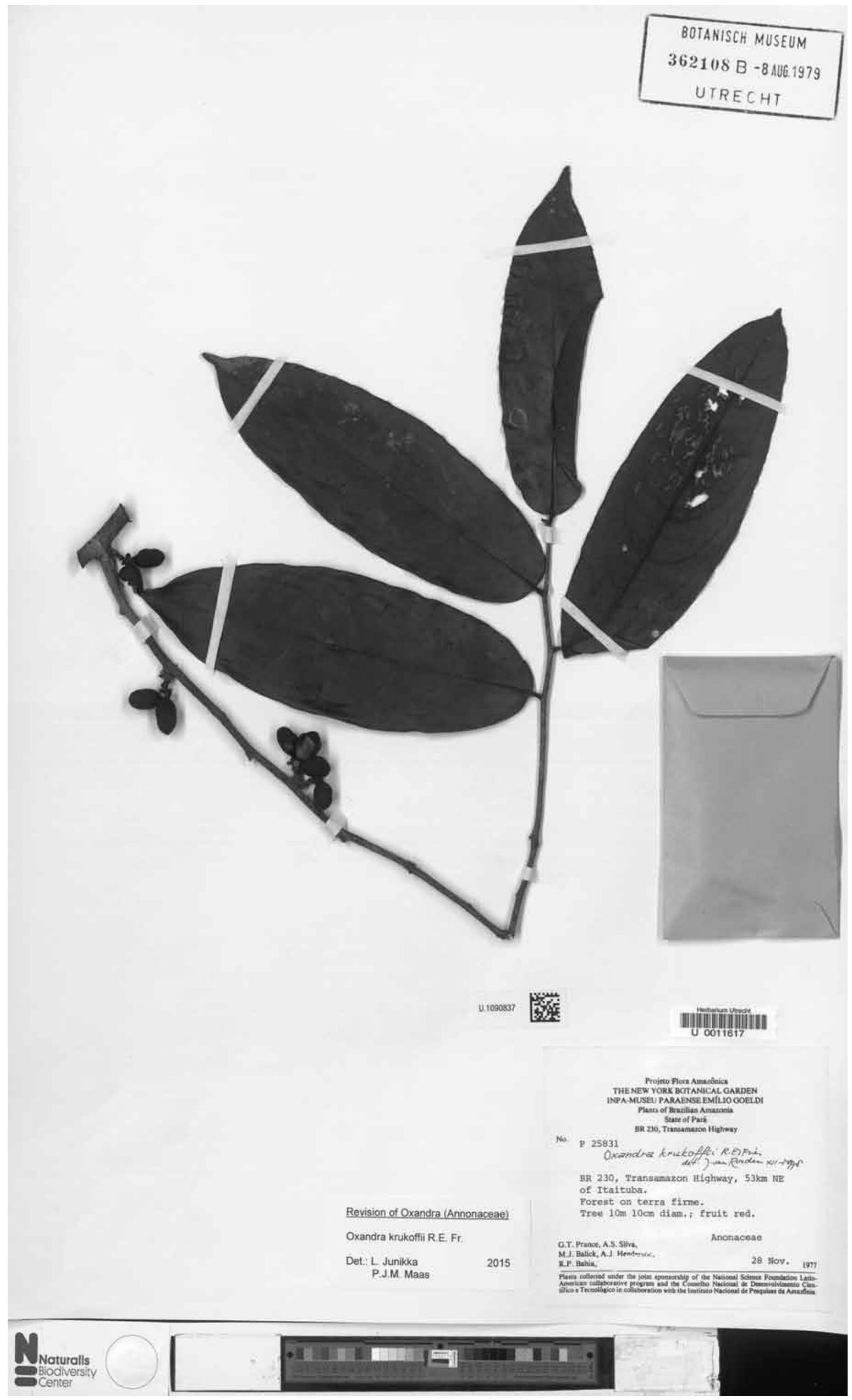

Fig. 7 Oxandra krukoffii R.E.Fr. Fruiting twig (Prance et al. 25831, U). 


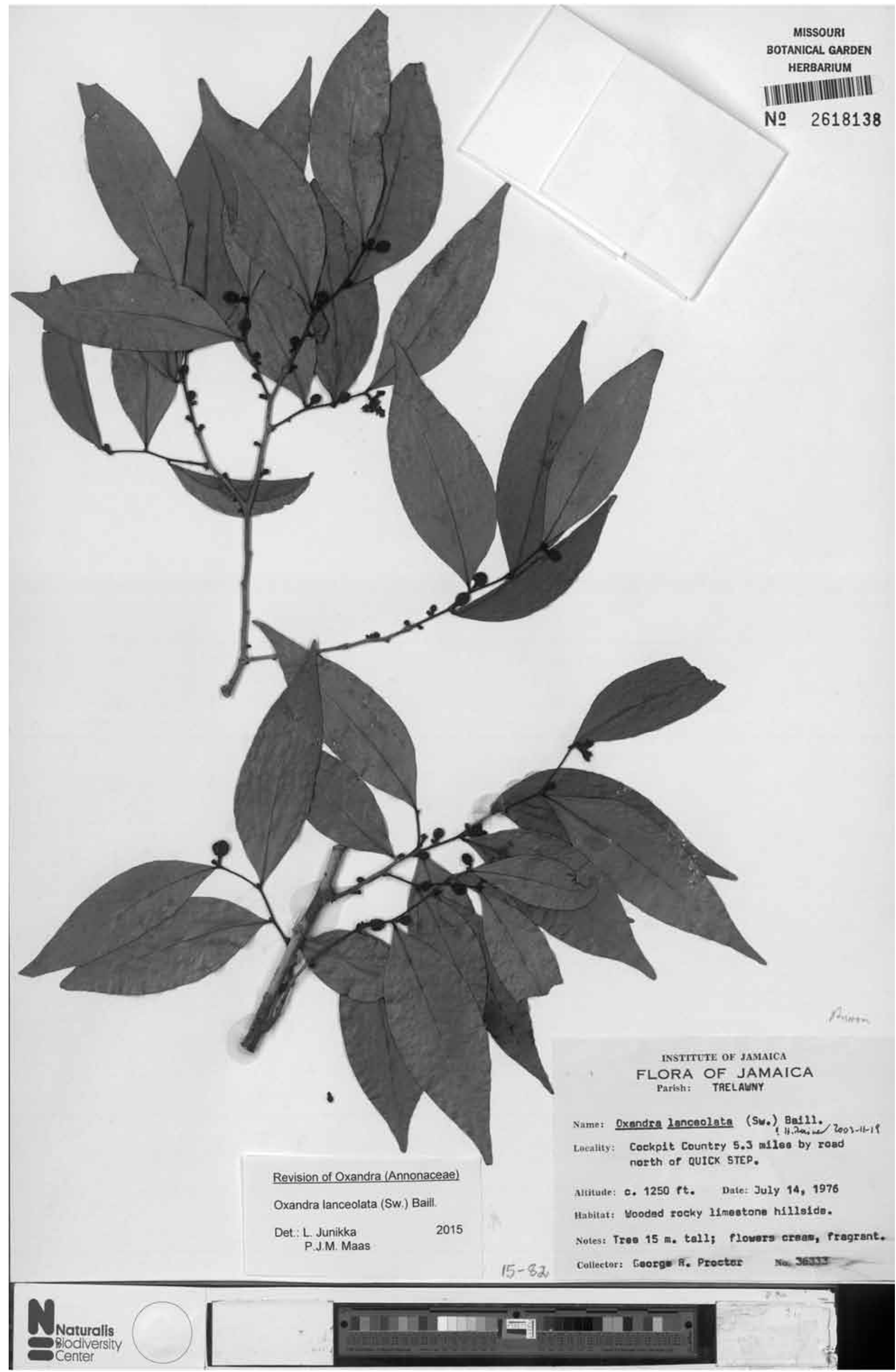

Fig. 8 Oxandra lanceolata (Sw.) Baill. Flowering twig (Proctor 36333, MO). 


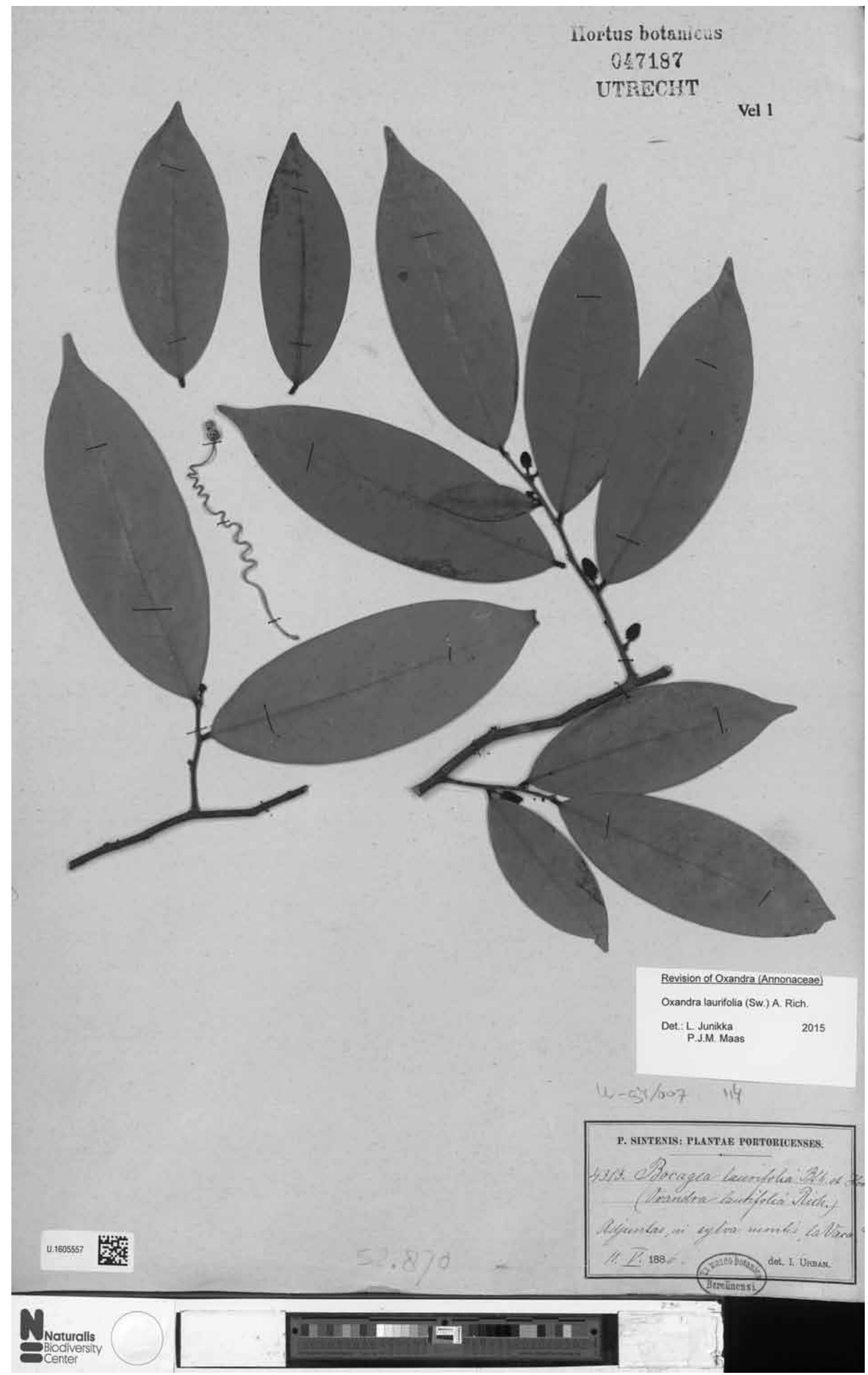

Fig. 9 Oxandra laurifolia (Sw.) A.Rich. Flowering twig (Sintenis 4313, U). 
Vernacular names - Brazil: Envira-preta (Krukoff 1124, N.T. Silva 1627), Envireira-forte (Capucho 558), Pinda'ywa (T.R. Bahia 2324, 2333, 2387, 2395, 2403, 2419, 2453, 2464, 2467), Taiassuba (Costa 53).

Uses - Comestible for curassows (fruit), fuel stuff (wood), tie stuff (bark fibers), element for house post (wood) (T.R. Bahia 2324, 2333, 2387, 2395, 2403, 2419, 2453, 2464, 2467, Brazil); ceilings and firewood (Capucho 558, Brazil); bark has a caustic material (Krukoff 1124, Brazil).

Note - Oxandra krukoffii superficially resembles $O$. euneura by its marginal vein and raised primary vein, but it strongly differs by its rounded instead of pointed fruits, which are much smaller (10-16 mm vs $10-30 \mathrm{~mm})$. Moreover, the distance from the marginal vein to the leaf margin is somewhat larger (5-7 mm in O. krukoffii vs $3-5 \mathrm{~mm}$ in O. euneura). Oxandra krukoffii is almost always ramiflorous!

\section{Oxandra lanceolata (Sw.) Baill. - Fig. 4d, 8; Plate 1h-i; Map 4}

Oxandra lanceolata (Sw.) Baill. (1868b) 168. — Uvaria lanceolata Sw. (1788) 87. - Uvaria virgata Sw. (1800) 999, nom. illeg. - Guatteria virgata (Sw.) Dunal (1817) 131, t. 31. - Oxandra virgata (Sw.) A.Rich. (1841) 20. - Bocagea virgata (Sw.) Benth. \& Hook.f. (1862) 29. - Cananga virgata (Sw.) A.DC. ex Baill. (1868b) 168. - Type: Swartz s.n. (holo S; iso BM, C, G, S), Jamaica.

Cananga lancea Poit. ex Dunal (1817) 132, nom. nud.

Oxandra punctuata C.Wright ex Griseb. (1861) 154, nom. nud.

Drimys lancea Poit. ex Baill. (1868b) 168, nom. nud.

Oxandra lanceolata (Sw.) Baill. subsp. macrocarpa R.E.Fr. (1956) 433, syn. nov.. - Type: Hinton 16177 (holo US; iso G, K, MICH, NY, UC, US), Mexico, Michoacán, Distr. Coalcoman, Ostula, 21 Nov. 1941.

Tree or shrub 2-20 m tall, 10-30 cm diam; young twigs rather densely covered with appressed hairs, soon glabrous. Leaves: petiole 1-2 mm long, 0.5-1 $\mathrm{mm}$ diam; lamina rhombic, ovate to narrowly ovate, $4-9(-10)$ by $1.5-3.5 \mathrm{~cm}$ (leaf index $2.5-$ $3.5(-4.5)$ ), chartaceous, rather densely to sparsely verruculose mostly below, dull and pale grey to greyish green above, greyish or brownish green below, glabrous above, sparsely covered with erect hairs to glabrous below, base acute to obtuse, apex bluntly acute, primary vein raised above, secondary veins distinct, 8-11 on either side of primary vein, raised above, angle of secondary veins with primary vein $45-65^{\circ}$, smallest distance between loops and margin 1-2 mm, tertiary veins raised above, reticulate. Flowers solitary; flowering and fruiting pedicels 1-3 mm long, 0.5-1 mm diam, glabrous; bracts 3-6, depressed ovate, $0.5-1 \mathrm{~mm}$ long, outer side sparsely covered with appressed hairs to glabrous; flower buds globose; sepals depressed ovate, c. 1 by $1-2 \mathrm{~mm}$, outer side glabrous; petals white in vivo, elliptic to obovate, $3-7$ by $3-4 \mathrm{~mm}$, outer side glabrous; stamens $10-15$, c. $2 \mathrm{~mm}$ long, apex of connective narrowly triangular; carpels $\leq 6$. Monocarps $1-4$, green, maturing maroon to black in vivo, black in sicco, ellipsoid to obovoid or broadly so, $8-15$ by $5-12 \mathrm{~mm}$, glabrous, apex rounded, wall $0.2-0.5 \mathrm{~mm}$ thick, stipes $1-2$ by $1-2 \mathrm{~mm}$. Seed ellipsoid, $7-12$

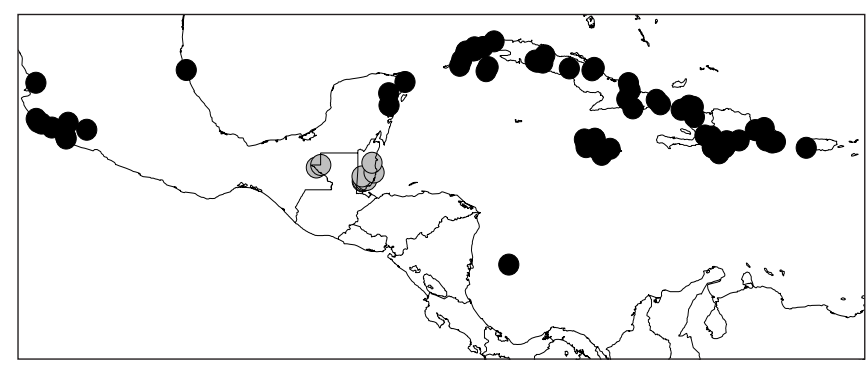

Map 4 Distribution of Oxandra lanceolata $(\bullet)$ and O. maya (○). by $4-10 \mathrm{~mm}$, brown, surface transversely striate, ruminations peg-shaped.

Distribution - Mexico (Colima, Guerrero, Jalisco, Michoacán, Nayarit, Puebla, Quintana Roo, Veracruz), Jamaica, Cuba, Haiti, Dominican Republic, Puerto Rico, Colombia (San Andrés y Providencia).

Habitat \& Ecology - Dry thickets, deciduous forest, or very humid forest, on shallow soils. At elevations of 0-700 m. Flowering: all year through; fruiting: all year through.

Vernacular names - Cuba: Lancewood (Wright 1102), Yaya (Crosby \& Matthews 15, Ekman 4178, 4468, 4581, 6078, 6162, 9466, Gill \& Whitford 9037). Dominican Republic: Yaya (Maas \& Zanoni 6395, Scarff 11H), Yaya fina (Scarff 11H). Haiti: Bois de lance (Ekman 459, Leonard \& Leonard 15560). Jamaica: Black lancewood (March 1675), Lancewood (Harris 7099, 9431). Mexico: Chilcahuite (Lott et al. 2895).

Uses - Fine wood used for supporting tiles for roofs where it will not get wet (Lott et al. 2895, Mexico).

Field observations - Fruit edible (Lott et al. 2895, Mexico).

Note - Oxandra lanceolata is one of the two Oxandra species inhabiting the Greater Antilles. It differs from the second species (O. laurifolia) by its almost rhombic (vs narrowly oblong-elliptic to narrowly obovate) leaves, globose (instead of ellipsoid) flower buds and shortly pedicellate flowers (pedicels $1-3$ vs $3.5-8 \mathrm{~mm})$.

\section{Oxandra laurifolia (Sw.) A.Rich. - Fig. 4e-g, 9; Map 5}

Oxandra laurifolia (Sw.) A.Rich. (1841) 20, t. 8. - Uvaria laurifolia Sw. (1800) 1001. - Guatteria laurifolia (Sw.) Dunal (1817) 132, t. 32. - Bocagea laurifolia (Sw.) Benth. \& Hook.f. (1862) 29. - Cananga laurifolia (Sw.) A.DC. ex Baill. (1868b) 168. - Type: Swartz s.n. (holo S; iso BM), Jamaica. Uvaria excelsa Vahl ex Dunal (1817) 132, nom. nud.

Cananga pseudolancea Poit. ex Dunal (1817) 132, nom. nud.

Uvaria dodecandra Sessé \& Moç. (1894) 133. - Type: not seen 'Habitat in montibus de Puerto Rico et Cuba'.

Anaxagorea acuminata auct. non (Dunal) A.DC.: Bello (1881) 234.

Tree 6-20 m tall, 10-35 cm diam; young twigs rather densely covered with appressed hairs, soon glabrous. Leaves: petiole 2-4 mm long, 1-2 mm diam; lamina narrowly oblong-elliptic to narrowly obovate, $7-17$ by $2-6 \mathrm{~cm}$ (leaf $2.5-3.4$ ), chartaceous, not verruculose or sparsely verruculose below, dull or sometimes shiny and greyish green above, greyish to brown below, glabrous above, sparsely covered with appressed hairs (sometimes $>1 \mathrm{~mm}$ long) below, base acute to obtuse, apex acuminate (acumen 5-20 mm long), primary vein flat above, secondary veins distinct, $10-13$ on either side of primary vein, raised above, angle of secondary veins with primary vein $45-80^{\circ}$, smallest distance between loops and margin 1-2 mm, tertiary veins flat above, reticulate. Flowers in 1-4(-10)-flowered inflorescences; pedicels 2-5 mm long, 0.5-1 mm diam, fruiting pedicels to c. $7 \mathrm{~mm}$ long, c. $2 \mathrm{~mm}$ diam, glabrous; bracts $4-5$, depressed ovate, $1-1.5 \mathrm{~mm}$ long, outer side densely to rather densely covered with appressed, brown hairs; flower

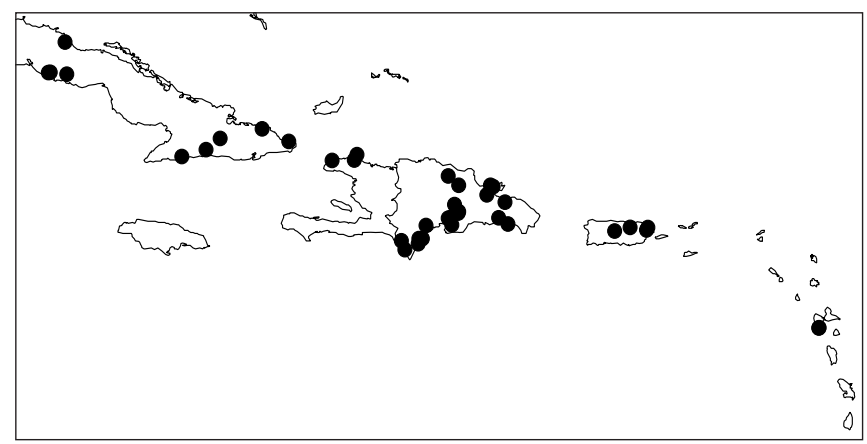

Map 5 Distribution of Oxandra laurifolia. 


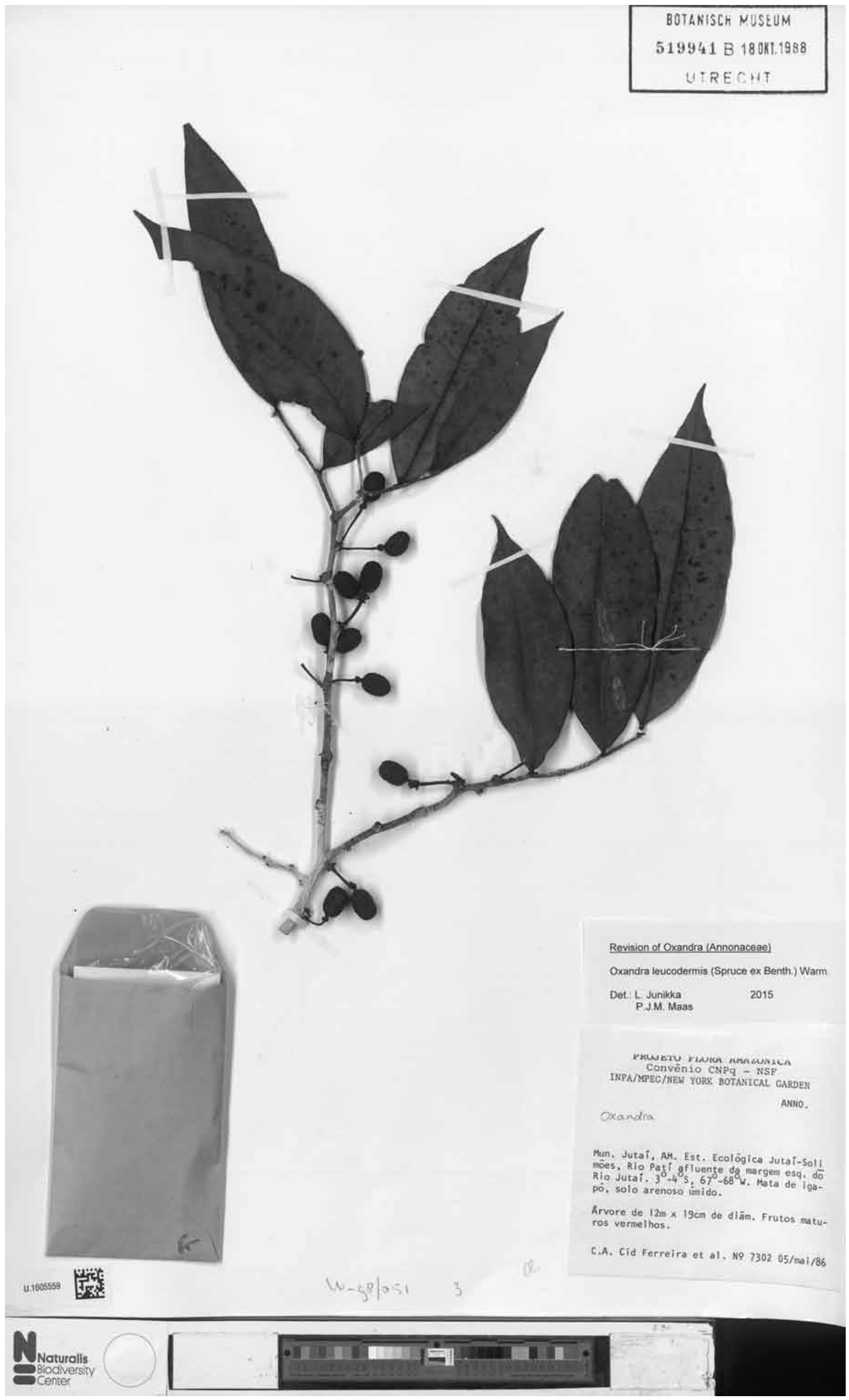

Fig. 10 Oxandra leucodermis (Spruce ex Benth.) Warm. Fruiting twig (Cid et al. 7302, U). 
buds ellipsoid; sepals broadly to shallowly ovate-triangular, $1-2$ by $1.5-2 \mathrm{~mm}$, outer side glabrous, rarely sparsely covered with appressed, brown hairs; petals white to yellow in vivo, ovate to elliptic, $7-8$ by $2-4 \mathrm{~mm}$, outer side glabrous; stamens 10-18, 2.5-3 mm long, apex of connective narrowly triangular; carpels $\leq 8$. Monocarps $2-7$, greenish yellow, yellow to dark maroon red in vivo, black in sicco, ellipsoid, $12-17$ by $8-10$ $\mathrm{mm}$, glabrous, apex apiculate (apiculum $0.2-1 \mathrm{~mm}$ long), wall $0.3-0.7 \mathrm{~mm}$ thick, stipes $3-8$ by $1-1.5 \mathrm{~mm}$. Seed ellipsoid, $12-15$ by $7-9 \mathrm{~mm}$, dark brown, surface transversely striate, ruminations spiniform.

Distribution - Cuba, Dominican Republic, Guadeloupe, Haiti, Jamaica, Puerto Rico, St. Kitts and Nevis, Saint Croix.

Habitat \& Ecology - In humid, montane forest, lowland forest, and gallery forest, on limestone, calcareous soils, or red sandy soils. At elevations of 0-1300 m. Flowering: February, April to June, August, November; fruiting: all year through.

Vernacular names - Cuba: Purio (De la Sagra 623, Ekman 1902, 2743, 4308, 5924, 6051, 18460, Luna 20). Dominican Republic: Lancewood (Von Eggers 2449), Yaiya (Zanoni et al. 34150), Yaya (Eggers 2449, Zanoni et al. 38122, Zanoni \& Pimentel 35994), Yaya boba (Scarff 11F), Yaya bobo (Schiffino 109), Yaya prieta (Jiménez et al. 1480). Guadeloupe: Bois de l'an (Duss 3058). Puerto Rico: Corcho blanco (Little 13754). St. Kitts and Nevis: Okra (Beard 460).

Field observations - Fleurs parfumées (Duss 3058, Guadeloupe); fruit with watery maroon red juice (Zanoni et al. 13443, Dominican Republic); Según los campesinos las aves se comen los frutos (Zanoni \& Pimentel 35994, Dominican Republic).

Note - Oxandra laurifolia is one of the two species of Oxandra occurring in the West Indies, but in contrast to O. lanceolata this species also occurs in the Lesser Antilles. For the differences between both species see under $\mathrm{O}$. lanceolata.

\section{Oxandra leucodermis (Spruce ex Benth.) Warm. - Fig} 4h, 10; Map 6

Oxandra leucodermis (Spruce ex Benth.) Warm. (1873) 147. - Bocagea leucodermis Spruce ex Benth. (1860) 71. - Type: Spruce 3352 (holo K iso B, BM, C, G, K, MPU, P, W), Venezuela, Amazonas, Río Pacimoni, side river of Río Casiquiare, Feb. 1854

Tree or shrub 6-20 m tall, 10-20 cm diam; young twigs whitish, glabrous. Leaves: petiole 2-5 mm long, 1-2 mm diam; lamina ovate to narrowly obovate, $8-20$ by $2-9 \mathrm{~cm}$ (leaf index

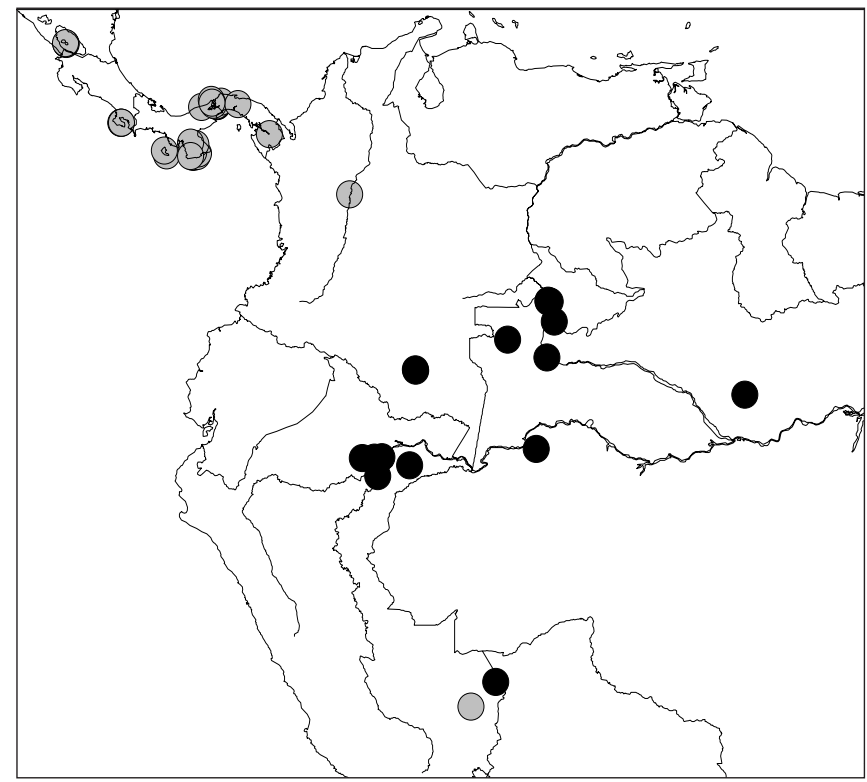

Map 6 Distribution of Oxandra leucodermis $(\bullet)$ and O. Iongipetala (○).
2.5-3.5), coriaceous, not verruculose, smooth, dull and brown to greyish green above, brown below, glabrous above and below, base acute to obtuse, often oblique and somewhat cordate, apex acuminate (acumen 5-25 mm long), primary vein raised above, secondary veins distinct, 8-14 on either side of primary vein, flat or raised above, angle of secondary veins with primary vein $45-80^{\circ}$, smallest distance between loops and margin 2-3 mm, tertiary veins indistinct, flat or slightly raised above, reticulate. Flowers in 1-2(-6)-flowered inflorescences on a cushion-like base, in the axils of mostly fallen leaves; pedicels 2-10 mm long, c. $0.5 \mathrm{~mm}$ diam, fruiting pedicels to c. $15 \mathrm{~mm}$ long, $0.5-1 \mathrm{~mm}$ diam, sparsely covered with appressed hairs to glabrous; bracts 5-6, depressed ovate, 1-2 mm long, outer side sparsely covered with appressed hairs to glabrous; flower buds subglobose, ellipsoid when mature; sepals shallowly to broadly ovate-triangular, $1-2$ by $1-2 \mathrm{~mm}$, outer side glabrous; petals white in vivo, ovate to elliptic, $4-6$ by $3-4 \mathrm{~mm}$, outer side glabrous; stamens c. 18, 1.5-2 mm long, apex of connective narrowly triangular to narrowly oblong; carpels $\leq 6$. Monocarps $1-6$, green, maturing dark red to black in vivo, brown to black in sicco, ellipsoid, $9-12$ by $6-9 \mathrm{~mm}$, glabrous, apex rounded, wall $0.2-0.3 \mathrm{~mm}$ thick, stipes $0.5-1$ by $1-2 \mathrm{~mm}$. Seed ellipsoid, $9-12$ by $6-8 \mathrm{~mm}$, pale brown, surface transversely striate, ruminations spiniform.

Distribution - Colombia (Amazonas), Venezuela (Amazonas), Peru (Loreto, Madre de Dios), Brazil (Amazonas).

Habitat \& Ecology - Mostly in periodically inundated (igapó, rebalse) forest, on white sand. At elevations of 0-300 m. Flowering: January; fruiting: January to May.

Vernacular names - Colombia: Eé-ña-moo-re (Yukuna name, Schultes \& Cabrera 16448). Peru: Espintana (Rimachi Y. 4356, 8818), Tortuga caspi (Armistead 1253, 1259), Tortuga caspi amarillo (Armistead 1208), Vara (Arévalo et al. 59, Vásquez et al. 7341). Venezuela: Palo paye (Liesner 6983).

Uses - Con el tronco se elaboran vigas para construir viviendas y los frutos son utilizados como carnada para pescar (Colombia: Sánchez Sáenz 1997).

Note - Oxandra leucodermis can be recognized by almost glabrous, relatively long and particularly slender pedicels up to c. $15 \mathrm{~mm}$ long, an often whitish bark, coriaceous and glabrous leaves with a raised primary vein. Moreover, the stipes of the monocarps are very short and slender $(0.5-1$ by $1-2 \mathrm{~mm})$.

\section{Oxandra longipetala R.E.Fr. — Fig. 11; Plate 2a, b; Map 6}

Oxandra longipetala R.E.Fr. (1931) 170, t. 5. - Type: Hayes 385 (holo K; iso BM), Panama, Lion Hill Station P.R.R., Aug. 1861.

Shrub or tree 2-10 $\mathrm{m}$ tall, 5-10 cm diam; young twigs densely to sparsely covered with erect hairs c. $1 \mathrm{~mm}$ long, finally glabrous. Leaves: petiole $0.5-2 \mathrm{~mm}$ long, $1-1.5 \mathrm{~mm}$ diam; lamina ovate to obovate, $4-12$ by $2-6 \mathrm{~cm}$ (leaf index $2.1-2.5$ ), chartaceous, not verruculose or sometimes sparsely verruculose below, dull and grey, greyish green to brown above and below, glabrous above, sometimes with appressed hairs along primary vein, rather densely to sparsely covered with erect or appressed hairs to glabrous below, base obtuse to slightly cordate and almost stem-clasping, often slightly oblique, apex acute to bluntly acuminate (acumen 5-20 mm long), primary vein raised above, secondary veins distinct, 8-10 on either side of primary vein, raised above, angle of secondary veins with primary vein $65-80^{\circ}$, smallest distance between loops and margin 1-4 mm, tertiary veins flat to slightly raised above, reticulate. Flowers solitary; pedicels 3-6 mm long, c. $0.5 \mathrm{~mm}$ diam, fruiting pedicels 6-10 mm long, 1-2 mm diam, densely covered with erect hairs to glabrous; bracts 4-6, depressed ovate, 1-2 mm long, outer side densely covered with appressed, white hairs to glabrous; flower buds subglobose, maturing ellipsoid; sepals shallowly to 


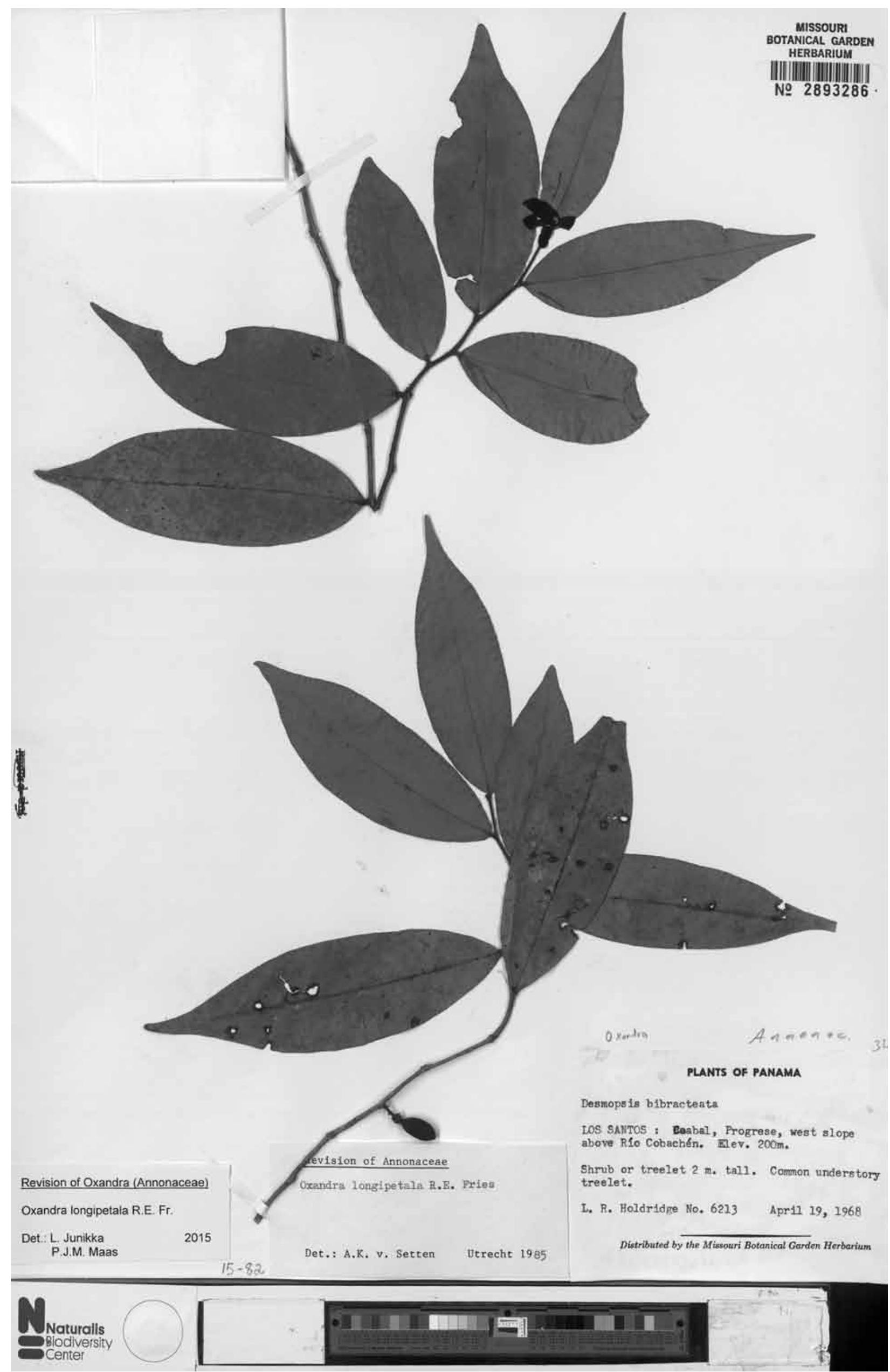

Fig. 11 Oxandra longipetala R.E.Fr. Flowering and fruiting twig (Holdridge 6213, MO). 

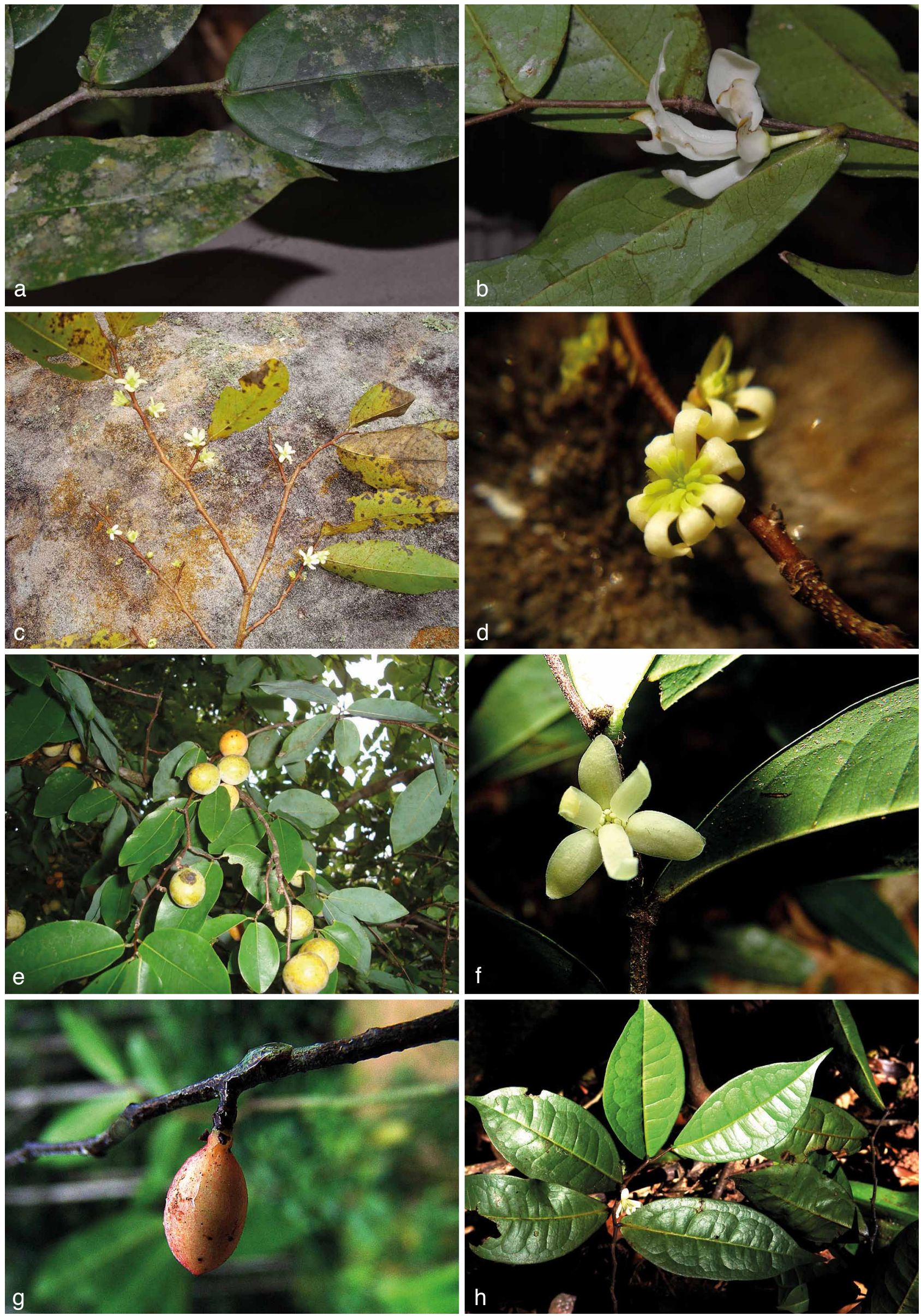

Plate 2 a-b. Oxandra longipetala R.E.Fr. a. Leaf, upper side; b. flower. - c-e. Oxandra saxicola Maas \& Junikka. c. Flowering twig; d. detail of flower; e. fruiting twig. - f-h. Oxandra surinamensis Jans.-Jac. f. Flowering twig; g. fruit; h. leafy twig (a, b: Maas et al. 10479; c, d: Parada 944; e: Parada 42; f-h: Bordenave et al. 8149). — Photos: a, b. P.J.M. Maas; c-e. G.A. Parada; f-h. B. Bordenave. 


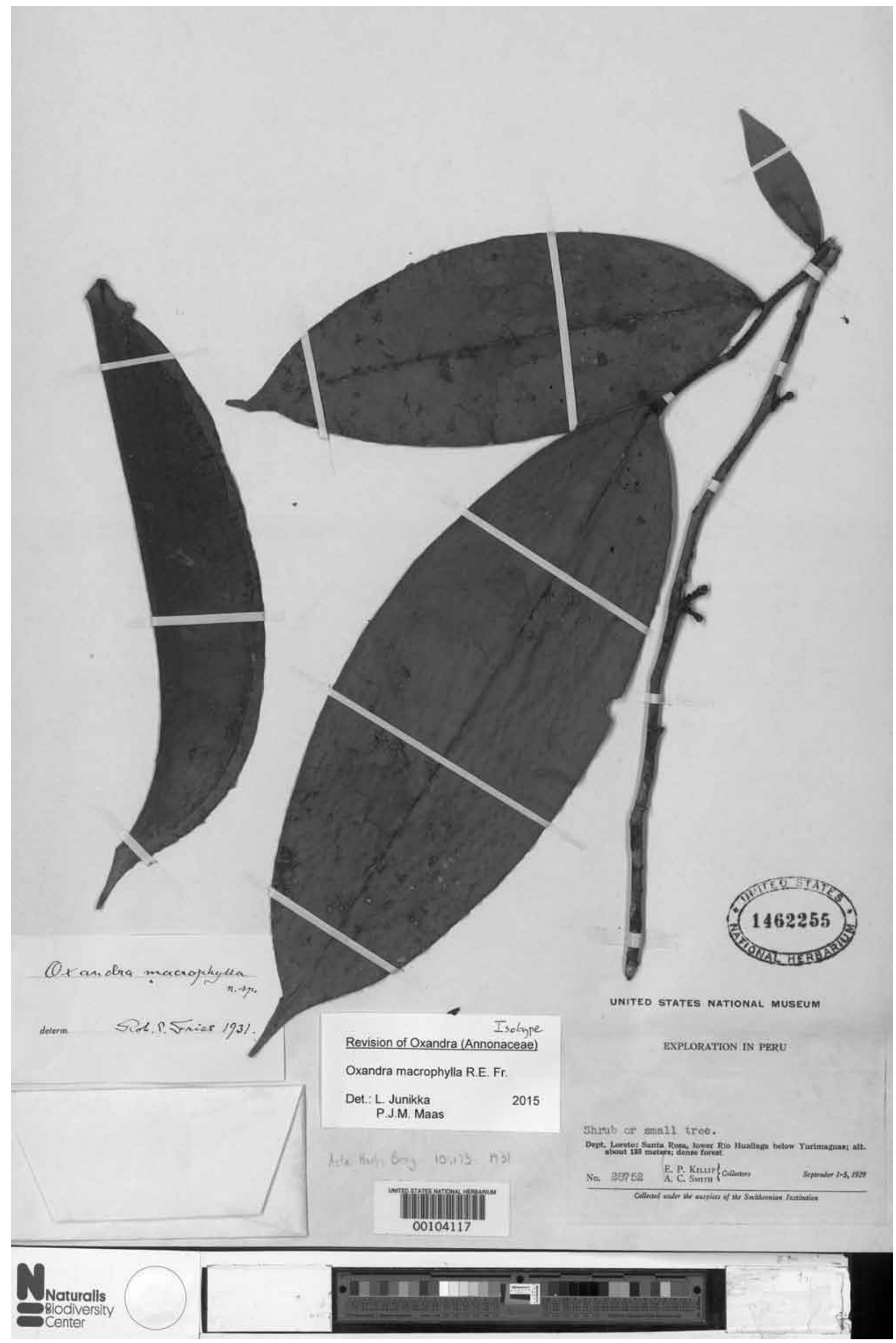

Fig. 12 Oxandra macrophylla R.E.Fr. Fruiting twig (Killip \& Smith 28752, iso US). 
broadly ovate-triangular, $1-2$ by $1-3 \mathrm{~mm}$, outer side densely covered with appressed, white hairs to glabrous; petals white in vivo, narrowly oblong-elliptic, $12-22$ by $3-7 \mathrm{~mm}$, outer side glabrous; stamens $30-40,1.5-2 \mathrm{~mm}$ long, apex of connective depressed ovate; carpels $\leq 11$. Monocarps $1-10$, green, maturing red, orange-red to black-purple in vivo, brown to black in sicco, ellipsoid to obovoid, $10-14$ by $5-8 \mathrm{~mm}$, sparsely covered with appressed hairs to glabrous, apex apiculate (apiculum $0.5-1 \mathrm{~mm}$ long), wall $0.2-0.3 \mathrm{~mm}$ thick, stipes $1-2$ by $1-2 \mathrm{~mm}$. Seed ellipsoid, c. 10 by $5-6 \mathrm{~mm}$, brown, surface transversely striate, ruminations spiniform.

Distribution - Nicaragua, Costa Rica, Panama, Colombia (Antioquia), Brazil (Pará), Peru (Puno).

Habitat \& Ecology - In premontane wet forest, deciduous forest, or gallery forest. At elevations of $0-1100 \mathrm{~m}$. Flowering: all year through; fruiting: from December to June.

Field observations - Flowers at anthesis with lemon-like smell (Chatrou et al. 114, Costa Rica); flores muy olorosas (Deago 488, Panama); flores frag(r)antes (Galdames et al. 2804, Panama); flowers fragrant (Gentry 2661, Panama); flowers sweetly aromatic (Stern et al. 1793, Panama).

Notes - Oxandra longipetala is a fairly easily recognizable species, characterized by very large petals (12-22 mm long) for the genus, young twigs which are covered with erect hairs (not often seen in the genus), a short petiole, and a leaf base which is rounded to cordate and unequal.

Amazingly Nuñez \& Munn 5313 (U) from the distant Peruvian Department of Puno exactly matches this species by an indument of erect hairs on the young twigs, and by its leaves and flowers.

Gentry 3285 (MO) from the Pipeline Road in Panama is distinctly cauliflorous, the fruit arising from the main stem. This is the first record for cauliflory in the genus.

\section{Oxandra macrophylla R.E.Fr. - Fig. 12, 13a; Map 7}

Oxandra macrophylla R.E.Fr. (1931) 173. - Type: Killip \& Smith 28752 (holo B; iso NY, US), Peru, Loreto, Santa Rosa, Lower Río Huallaga, below Yurimaguas, $135 \mathrm{~m}$, Sept. 1929.

Shrub or tree 3-13 m tall, 4-13 cm diam; young twigs densely covered with erect, brown hairs, soon glabrous. Leaves: petiole 1-5 mm long, 2-3 mm diam; lamina ovate to obovate or narrowly so, $17-26$ by $6-12 \mathrm{~cm}$ (leaf index $2.1-3.4$ ), chartaceous, densely verruculose above and below, dull and grey to brown-

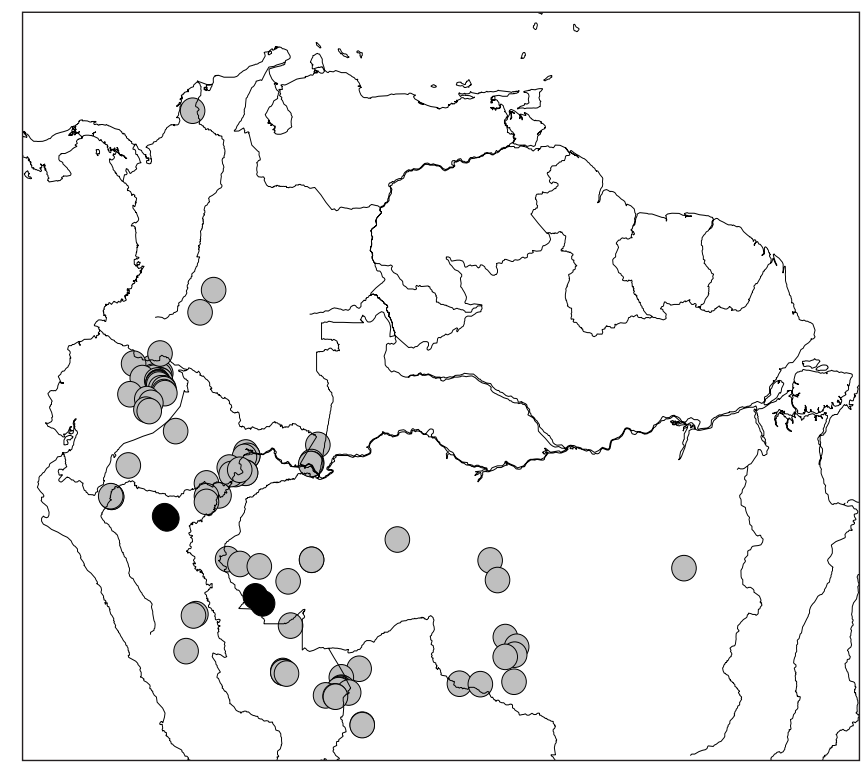

Map 7 Distribution of Oxandra macrophylla (๑) and O. mediocris (O). ish green above, greyish brown to brown below, glabrous, but primary vein densely covered with erect hairs to c. $2 \mathrm{~mm}$ long above, rather densely to sparsely covered with erect and appressed hairs below, base acute to slightly cordate, apex acuminate (acumen 15-20 mm long), primary vein impressed above, secondary veins distinct, $15-20$ on either side of primary vein, slightly raised above, angle of secondary veins with primary vein $65-80^{\circ}$, smallest distance between loops and margin 2-5 mm, tertiary veins flat to slightly raised above, reticulate to percurrent. Flowers in 1-2-flowered inflorescences; flowering pedicels not seen, fruiting pedicels $3-5 \mathrm{~mm}$ long, 1-2 $\mathrm{mm}$ diam, glabrous; bracts 5-6, depressed ovate, 1.5-2 mm long, outer side rather densely covered with appressed hairs to glabrous; flower buds ellipsoid; sepals depressed ovate, 1.5-2 by $1.5-2 \mathrm{~mm}$, outer side sparsely to rather densely covered with appressed hairs; petals white in vivo, elliptic to obovate, $4-8$ by $2-5 \mathrm{~mm}$, outer side glabrous; stamens $5-18,1.5-2.5$ $\mathrm{mm}$ long, apex of connective ovate-triangular; carpels $\leq 5$. Monocarps 5-20, colour in vivo not recorded, black in sicco, ellipsoid, $17-20$ by $7-9 \mathrm{~mm}$, glabrous, apex apiculate (apiculum $<0.5 \mathrm{~mm}$ long), wall c. $0.5 \mathrm{~mm}$ thick, stipes $3-6.5$ by $1-2 \mathrm{~mm}$. Seed ellipsoid, 17-20 by 7-9 mm, brown, surface transversely striate, ruminations spiniform or peg-shaped.

Distribution - Amazonian Brazil (Acre, Amazonas) and Peru (Loreto).

Habitat \& Ecology - In non-inundated or periodically inundated (tahuampa, várzea) forest. At elevations of 0-200 m. Flowering: June; fruiting: May, September, October.

Vernacular name - Peru: Chuchuhuasha mashan (LI. Williams 4129).

Note - A characteristic of $O$. macrophylla are the (often) large leaves with an impressed primary vein densely covered with long erect hairs above. In this aspect it is easily distinguished from large-leaved forms of $O$. xylopioides which lack such hairs and which have, moreover, a leaf base with two tooth-like projections.

\section{Oxandra martiana (Schltdl.) R.E.Fr. - Fig. 14; Map 2}

Oxandra martiana (Schltdl.) R.E.Fr. (1931) 165, f. 4d, e. — Guatteria martiana Schltdl. (1834) 326. - Type: Sellow B1970, C 1483 (holo B; iso K 2 sheets, P, S), Brazil, Minas Gerais, 'Guidowald', Feb. 1819

Oxandra reinhardtiana Warm. (1873) 147. - Type: Warming s.n. (lecto C; syn C, P, W), Brazil, Minas Gerais, Lagoa Santa. Of the four syntypes in $C$ the Warming specimen numbered 26/94 no. 21 (the loan number) and with a label 'Nov. Decbr.' is herewith selected as the lectotype.

Tree or shrub 6-30 m tall, 8-50 cm diam; young twigs sparsely covered with appressed hairs, glabrous. Leaves: petiole 2-4 $\mathrm{mm}$ long, 1-2 $\mathrm{mm}$ diam; lamina narrowly ovate to narrowly obovate, $6-14$ by $1.5-3 \mathrm{~cm}$ (leaf index $3-4.6$ ), chartaceous, densely verruculose to not verruculose above and densely to sparsely verruculose below, dull to slightly shiny and greyish to brownish green above, brownish below, glabrous above, sparsely covered with appressed hairs mainly along the primary vein below, base acute, apex acuminate (acumen to c. $10 \mathrm{~mm}$ long), primary vein impressed to flat above, secondary veins distinct, 8-14 on either side of primary vein, raised above, angle of secondary veins with primary vein $65-80^{\circ}$, smallest distance between loops and margin $2-3 \mathrm{~mm}$, tertiary veins slightly raised above, reticulate. Flowers solitary; pedicels $1-2 \mathrm{~mm}$ long, c. 0.5 $\mathrm{mm}$ diam, fruiting pedicels $2-6 \mathrm{~mm}$ long, $0.5-2 \mathrm{~mm}$ diam, glabrous; bracts (3-)6-12, depressed ovate, $0.5-1.5 \mathrm{~mm}$ long, outer side glabrous; flowers bisexual or rarely male (plant androdioecious); flower buds ellipsoid; sepals depressed ovate, c. 1.5 by $2 \mathrm{~mm}$, outer side glabrous or sparsely covered with appressed hairs; petals white in vivo, ovate, elliptic, to linear, $7.5-8$ by $3-4 \mathrm{~mm}$, outer side glabrous; stamens $12-15,2-3$ $\mathrm{mm}$ long, apex of connective narrowly triangular; carpels $\leq 12$. 

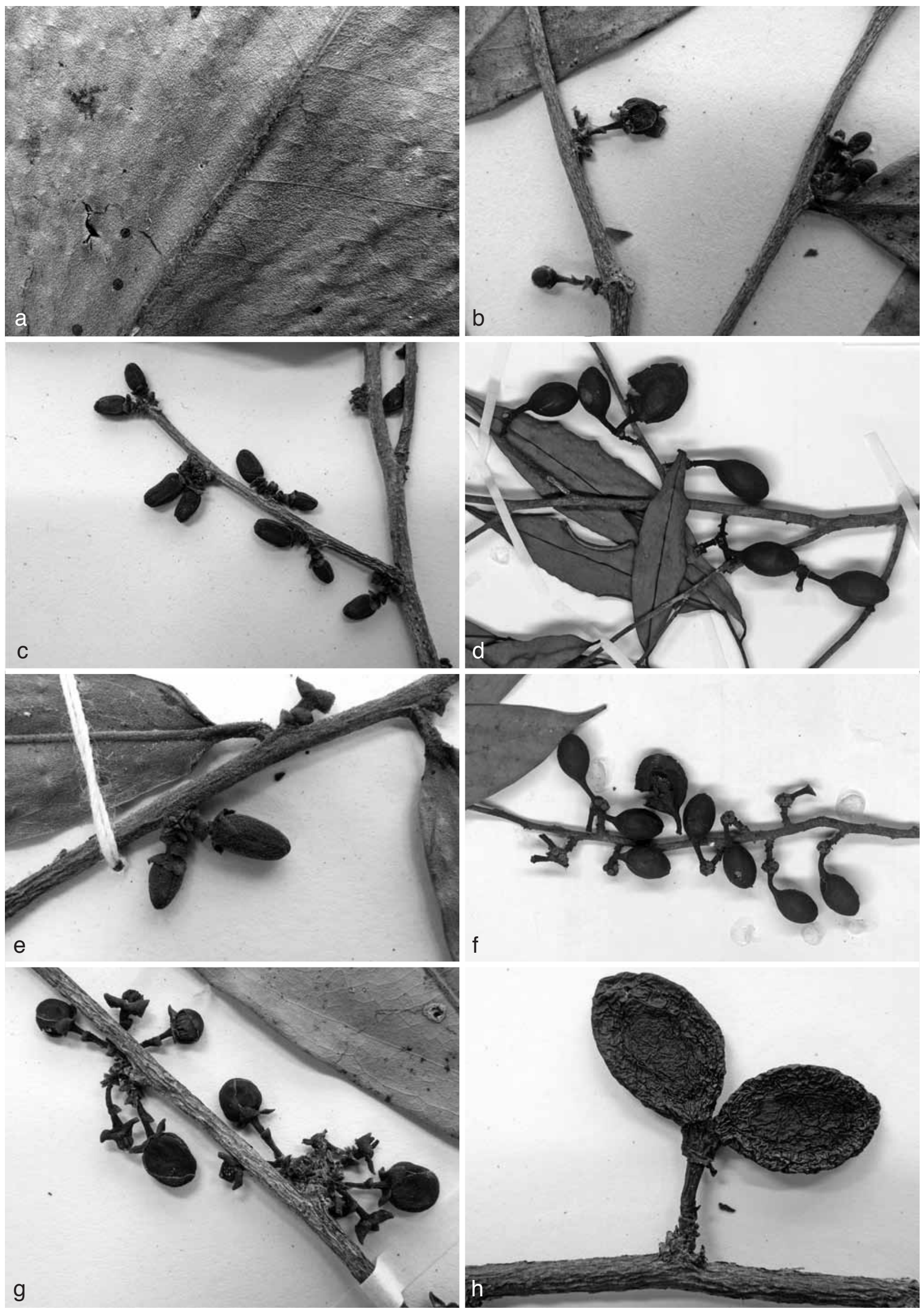

Fig. 13 a. Oxandra macrophylla R.E.Fr. Detail of upper side of lamina, showing verruculae and hairy primary vein. — b. Oxandra maya Miranda. Detail of flower and (young) fruit. — c, d. Oxandra mediocris Diels. c. Detail of flowers; d. detail of fruiting twig. — e, f. Oxandra panamensis R.E.Fr. e. Detail of flower; f. detail of fruiting twig. - g, h. Oxandra polyantha R.E.Fr. g. Detail of inflorescence; h: detail of fruit (a: Killip \& Smith 28752, iso US; b: Contreras 5379; isotype of O. guatemalensis Lundell, F; c: Timaná 2327, U; d: Alexiades \& Pesha 367, U; e: Feddema 2099, US; f: Feddema 1879, MICH; g: Nelson et al. 515, U; h: Chatrou et al. 150, U). 


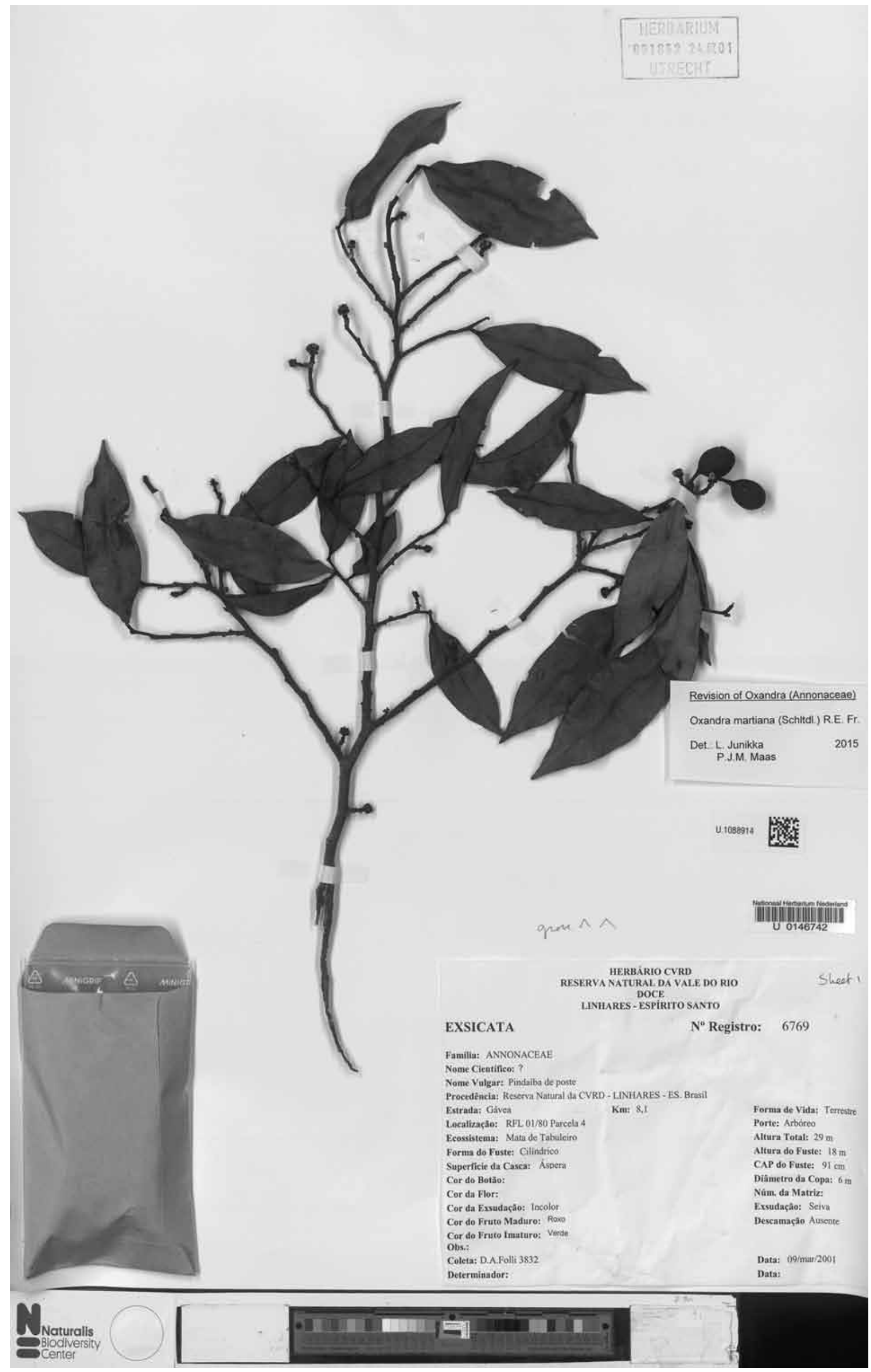

Fig. 14 Oxandra martiana (Schltdl.) R.E.Fr. Fruiting twig (Folli 3832, U). 


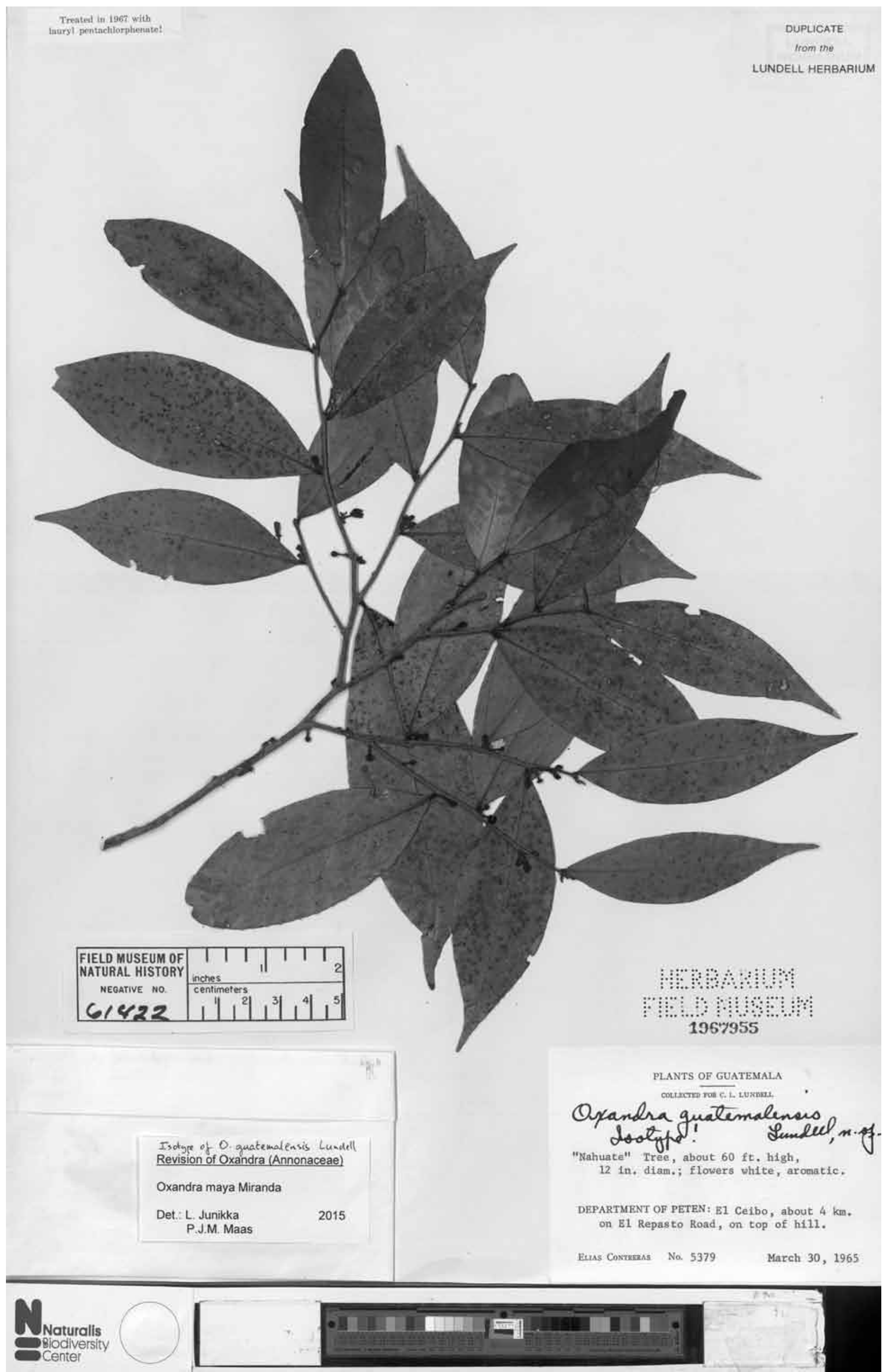

Fig. 15 Oxandra maya Miranda. Flowering and fruiting twig (Contreras 5379; isotype of O. guatemalensis Lundell, F). 
Monocarps 4-12, colour in vivo not recorded, black in sicco, ovoid to ellipsoid, $10-18$ by $8-15 \mathrm{~mm}$, glabrous, apex rounded, wall $0.5-2 \mathrm{~mm}$ thick, stipes $2-3(-7)$ by $1-2 \mathrm{~mm}$. Seed ovoid to ellipsoid, $9-13$ by $7-9 \mathrm{~mm}$, brown, surface transversely striate, ruminations spiniform.

Distribution - Brazil (Espírito Santo, Minas Gerais, Rio de Janeiro).

Habitat \& Ecology — In Atlantic forest. Elevations 0-800 m. Flowering: October to December; fruiting: February, March.

Vernacular names - Brazil: Imbiú-preto (Kurtz et al. s.n.), Pindaíba (Lopes \& Andrade 840), Pindaíba-de-poste (Folli $3753,3832,3833)$.

Note - Some notable features of 0 . martiana are rather narrow leaves, ellipsoid flower buds and rather large fruits. It comes close to $O$. espintana, from which it differs, however, by larger monocarps (10-18 $\mathrm{mm}$ vs $7-13 \mathrm{~mm}$ long) and a thicker fruit wall $(0.5-2 \mathrm{~mm}$ vs $0.2-0.5 \mathrm{~mm}$ thick).

\section{Oxandra maya Miranda - Fig. 13b, 15; Map 4}

Oxandra maya Miranda (1961) 120, f. 1. - Type: Miranda 8471/2 (holo MEXU; iso US), Mexico, Chiapas, Carretera La Arena (a Salas), c. 10 km NW of Santa Margarita, 12 Mar. 1957.

Amyris belizensis Lundell (1941) 32, syn. nov. — Oxandra belizensis (Lundell) Lundell (1974a) 28. - Type: Gentle 1720 (holo LL), Belize, Belize District, Gracie Rock, Sibun River, 20 Aug. 1935.

Oxandra guatemalensis Lundell (1974a) 29, syn. nov. - Type: Contreras 5379 (holo LL; iso F, K, MO), Guatemala, Petén, El Ceibo, c. 4 km on E Repasto Road, on top of hill, 30 Mar. 1965

Oxandra proctorii Lundell (1974b) 54, syn. nov. - Type: Proctor 30104 (holo LL; iso BM, MO), Belize, El Cayo, 2.2 miles SE of Holec Camp, Chiquibul Forest Reserve, 1600-1700 ft, 25 Apr. 1969.

Tree 5-30 m tall, 20-45 cm diam; young twigs sparsely covered with appressed hairs, soon glabrous. Leaves: petiole $1-3 \mathrm{~mm}$ long, $0.5-1 \mathrm{~mm}$ diam; lamina narrowly elliptic to narrowly ovate, rhombic, or ovate, $5-12$ by $1-4 \mathrm{~cm}$ (leaf index 2.7-4.4), chartaceous, rather densely verruculose below, shiny and greyish green above, greyish green to brown below, glabrous above, rather densely covered with appressed and erect hairs to glabrous below, base acute, apex long-acute to acuminate (acumen 5-10 mm long), primary vein flat, rarely raised above, secondary veins distinct, $6-10$ on either side of primary vein, slightly raised above, angle of secondary veins with primary vein $45-65^{\circ}$, smallest distance between loops and margin 1-2 $\mathrm{mm}$, tertiary veins slightly raised above, reticulate. Flowers in 1-4-flowered inflorescences; flowering and fruiting pedicels 3-5 mm long, c. $1 \mathrm{~mm}$ diam, sparsely covered with appressed hairs to glabrous; bracts $4-5$, depressed ovate, c. 1 by 1.5 $\mathrm{mm}$, outer side rather densely covered with appressed hairs; flowers bisexual or rarely male (plant androdioecious); flower buds globose; sepals shallowly ovate-triangular, c. 1 by $1.5-2$ $\mathrm{mm}$, outer side rather densely to sparsely covered with pressed hairs; petals white to cream in vivo, elliptic, c. 5 by $2-3 \mathrm{~mm}$, outer side sparsely covered with appressed hairs to glabrous; stamens c. $10,2.5-3 \mathrm{~mm}$ long, apex of connective narrowly triangular; carpels $\leq 9$. Monocarps $2-6$, green in vivo, black to brown in sicco, obovoid to ellipsoid, $10-12$ by $6-10 \mathrm{~mm}$, glabrous, apex rounded, wall $0.2-0.5 \mathrm{~mm}$ thick, stipes $1-3$ by 1 $\mathrm{mm}$. Seed ellipsoid, c. 10 by $5 \mathrm{~mm}$, brown, surface transversely striate, ruminations spiniform or peg-shaped.

Distribution - Mexico (Chiapas), Guatemala, Belize.

Habitat \& Ecology — In lowland, tall, tropical forest, on calcareous soil. At elevations of $0-800 \mathrm{~m}$. Flowering: March, August; fruiting: March to May, November.

Vernacular names - Guatemala: Nahuate (Contreras 5379). Mexico: Nahuacté (Gomez-Pompa 306, Miranda 8471/2).

Field observations - Flowers aromatic (Contreras 5379, Guatemala).
Note - Oxandra maya is recognizable by small leaves with a primary vein flat (or rarely) raised on the upper side, and a lower side which is distinctly verruculose. Flower buds are globose and the petals glabrous. It has pedicels to $5 \mathrm{~mm}$ long and shortly stipitate, small monocarps. It closely resembles 0 . lanceolata, but can be differentiated from that species by 1-4-flowered (vs 1-flowered) inflorescences, and slightly longer pedicels ( $3-5$ vs $1-3 \mathrm{~mm}$ ).

\section{Oxandra mediocris Diels — Fig. 13c, d, 16; Map 7}

Oxandra mediocris Diels (1905) 125. - Type: Ule 5796 (holo B; iso F, G, HBG, K 2 sheets, MO, S), Brazil, Acre, Rio Jurua-Mirim, Sept. 1901. Oxandra acuminata Diels (1906) 410. - Type: Weberbauer 1897 (holo B), Peru, Junín, Prov. Tarma, near La Merced (in Chanchamayo valley), 1000 m, Dec. 1902.

Tree 6-30 m tall, 10-70 cm diam; young twigs densely covered with appressed to semierect hairs, soon glabrous. Leaves: petiole 1-3 mm long, 1-2 $\mathrm{mm}$ diam; lamina narrowly elliptic to narrowly obovate, $5-10$ by $2-3 \mathrm{~cm}$ (leaf index $2.7-3.3$ ), coriaceous, densely to sparsely verruculose above and below, dull and often greyish brown above, greyish brown below, glabrous above, sparsely covered with appressed hairs below, base acute, apex acuminate (acumen $20-30 \mathrm{~mm}$ long), primary vein flat to impressed above, secondary veins indistinct, 9-15 on either side of primary vein, raised above, angle of secondary veins with primary vein $45-65^{\circ}$, smallest distance between loops and margin 1-2 mm, tertiary veins flat above, reticulate. Flowers in 1(-3)-flowered inflorescences; pedicels 2-3 mm long, $0.5-1 \mathrm{~mm}$ diam, fruiting pedicels $2-5 \mathrm{~mm}$ long, 1-2 $\mathrm{mm}$ diam, rather densely covered with appressed hairs to glabrous; bracts $4-5$, depressed ovate, $0.5-1 \mathrm{~mm}$ long, outer side densely to rather densely covered with appressed hairs; flowers bisexual or rarely male (plant androdioecious); flower buds ellipsoid; sepals broadly ovate-triangular, c. 1 by $1 \mathrm{~mm}$, outer side rather densely covered with appressed hairs; petals green, yellow, or white in vivo, narrowly elliptic, $6-9$ by 2-3 $\mathrm{mm}$, outer side sparsely to rather densely covered with appressed hairs; stamens 10-25, c. $2.5 \mathrm{~mm}$ long, apex of connective narrowly triangular; carpels $\leq 12$. Monocarps $7-12$, green, maturing yellow to orange and black in vivo, black in sicco, ellipsoid, $10-15$ by $7-10 \mathrm{~mm}$, glabrous, apex apiculate (apiculum $<0.5 \mathrm{~mm}$ long) or not, wall $0.3-0.4 \mathrm{~mm}$ thick, stipes $3-5$ by $1-1.5 \mathrm{~mm}$. Seed ellipsoid, $10-12$ by $5-8 \mathrm{~mm}$, pale reddish brown, surface minutely pitted to transversely striate, ruminations spiniform.

Distribution - Colombia (Amazonas, Caquetá, Bolivar, Meta), Ecuador (Napo, Pastaza, Sucumbios, Orellana), Peru (Amazonas, Huánuco, Junín, Loreto, Madre de Dios, Ucayali), Bolivia (La Paz, Pando), Brazil (Acre, Amazonas, Pará, Rondônia).

Habitat \& Ecology - In non-inundated or periodically inundated (igapó, tahuampa or várzea) forest. At elevations of 0-350(-1700) m. Flowering: all year through; fruiting: all year through.

Vernacular names - Bolivia: Piraquina (DeWalt 16), Piraquina colorada (L. Vargas et al. 146), Sipiko (Tacana name, DeWalt 16). Brazil: Vassourinha (Daly et al. 8782). Colombia: Faak+o cugao (Muinane name, Murillo \& Rodríguez A. 562). Ecuador: Anshilo caspi (Quichua name, Gudiño \& Andi 2086), Moncataweimo (Huaorani name, Dik \& Andi 934), Uñitahue (Huaorani name, Aulestia \& Ima 1578). Peru: Espintana (Kröll Saldaña 536, 537, 538, 540, 648, 650, 655, 657, 754, 762, 771, 777, Tello E. 331, 513, 1118, 1150, 1291), Espintana negra (Flores \& Tello E. 435, 523, 546, 649, 724, 775, 2053, Kröll Saldaña 146, 157, 183, 545, 664, Tello E. 2942, 2968), Kepiseróki (Weiss 184), Micha (Ese-ejha) (Alexiades et al. 98, 112, 160, 164, 197, 203, 274, 291, 295, 322, 367), Pintana (Alexiades et al. 203), Pintana colorada (Alexiades et al. 152), 


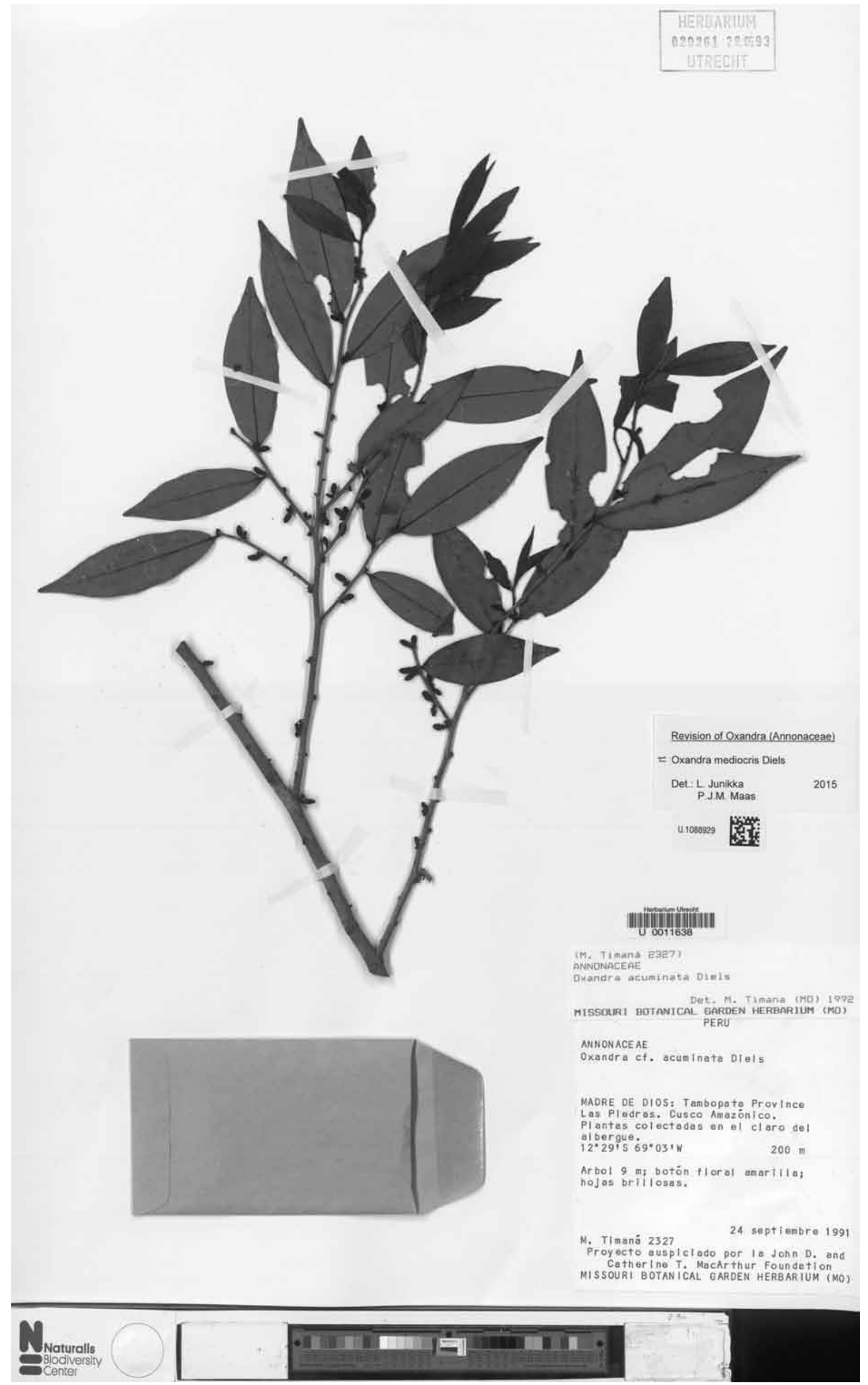

Fig. 16 Oxandra mediocris Diels. Flowering twig (Timaná 2327, U). 
Pintana negra (Alexiades et al. 98, 112, 160, 164, 197, 274, 291, 295, 322, 367).

Uses - Element for house beams and poles (Alexiades et al. 98, Peru); wood used for house rafters (Daly et al. 8782, Bolivia); corteza fuerte, facil para sacar panchos (DeWalt 16, Bolivia); construcción para casa y armasón (DeWalt 16, Bolivia); con el tronco se elaboran vigas para construir viviendas (Colombia: Sánchez Sáenz 1997); se utiliza para hacer casas (Tunqui 192, Peru).

Note - Oxandra mediocris is recognizable by its small leaves, ellipsoid flower buds, and distinctly stipitate monocarps (stipes 3-5 mm long). It resembles some small-leaved species of Xylopia (and therefore is sometimes confused with that genus).

\section{Oxandra panamensis R.E.Fr. - Fig. 13e, f, 17; Map 8}

Oxandra panamensis R.E.Fr. (1931) 168, f. 5c. - Type: R.S. Williams 1017 (holo NY; iso NY, US), Panama, Marraganti and vicinity, 10-220 ft, $5 \mathrm{Apr}$. 1908

Oxandra oblongifolia R.E.Fr. (1931) 169, f. 5d, syn. nov. - Type: Pennell 4633 (holo NY), Colombia, Bolívar, Tierra Alta, Río Sinu, 100-200 m, 7-10 Mar. 1918.

Tree or shrub 6-12 m tall, 6-15 cm diam; young twigs densely to rather densely covered with appressed to erect, brown hairs, soon glabrous. Leaves: petiole $2-5 \mathrm{~mm}$ long, $1-1.5 \mathrm{~mm}$ diam; lamina narrowly ovate to narrowly obovate, $7-14$ by $2-4.5 \mathrm{~cm}$ (leaf index 2.8-4.2), chartaceous, densely to rather densely verruculose above and below, dull and greyish or brownish green above, brownish green to brown below, glabrous above, rather densely to sparsely covered with appressed, white hairs, mainly on the primary vein below, base acute to obtuse, rarely with two angular to tooth-like projections on either side when young, apex long-acute to acuminate (acumen 5-15 mm long), primary vein impressed to flat above, secondary veins indistinct, 14-17 on either side of primary vein, raised to flat above, angle of secondary veins with primary vein $65-80^{\circ}$, smallest distance between loops and margin 1-3 $\mathrm{mm}$, tertiary veins flat above, reticulate. Flowers in 1-3-flowered inflorescences; flowering pedicels $2-3 \mathrm{~mm}$ long, c. $1 \mathrm{~mm}$ diam, fruiting pedicels $2-6 \mathrm{~mm}$ long, 1-3 mm diam, rather densely covered with appressed hairs to glabrous; bracts 4-6, depressed ovate, 1-2 mm long, outer side densely covered with appressed hairs to glabrous; flowers bisexual or male (plant androdioecious); flower buds ellipsoid; sepals broadly to shallowly ovate-triangular, $1-2$ by $1.5-2.5 \mathrm{~mm}$, outer side rather densely to sparsely covered with appressed hairs; petals cream in vivo, elliptic, $5-6$ by $2.5-3$ $\mathrm{mm}$, outer side rather densely covered with appressed hairs;

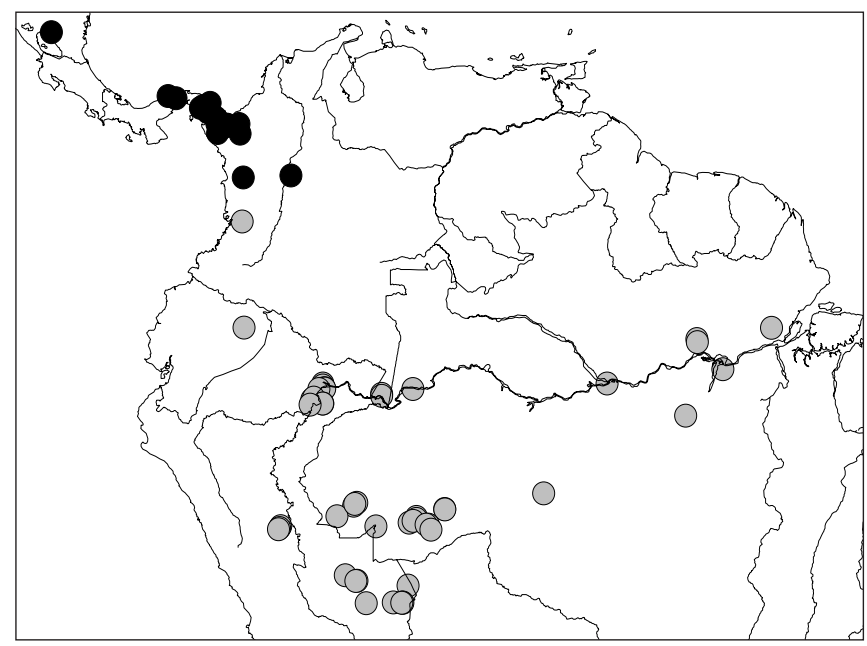

Map 8 Distribution of Oxandra panamensis (๑) and O. polyantha (৩). stamens c. 12 , c. $1.5 \mathrm{~mm}$ long, apex of connective narrowly triangular; carpels not seen. Monocarps 5-25, green, maturing yellow, orange to purple-black in vivo, black in sicco, ovoid, obovoid, ellipsoid, or globose, $12-22$ by $9-13 \mathrm{~mm}$, glabrous, apex apiculate (apiculum $0.1-0.5 \mathrm{~mm}$ long), wall $0.5-1 \mathrm{~mm}$ thick, stipes $1-7$ by $1 \mathrm{~mm}$. Seed ellipsoid, $10-15$ by $7-10 \mathrm{~mm}$, brown, surface transversely striate, ruminations spiniform or pegshaped.

Distribution - Nicaragua, Panama, Colombia (Antioquia, Bolívar, Boyacá, Chocó).

Habitat \& Ecology - In lowland, tropical non-inundated moist forest. At elevations of 0-1000 m. Flowering: February to April; fruiting: all year through.

Vernacular names - Panama: Uichur-chichit (Kuna name, Dalle 201), Yaya (Duke 6533, 8046, Stern et al. 945), Yaya negra (Duke 14242).

Uses - Wood a good one for canoe poles (Duke 14242, Panama).

Note - Oxandra panamensis, including O. oblongifolia, comes close to $O$. xylopioides. For differences between both species see under the latter.

\section{Oxandra polyantha R.E.Fr. — Fig. 13g, h, 18; Map 8}

Oxandra polyantha R.E.Fr. (1937) 269. - Type: Krukoff 5628 (holo S; iso $\mathrm{G}, \mathrm{K}, \mathrm{MICH}, \mathrm{U})$, Brazil, Acre, near mouth of Rio Macauhan, tributary of Rio Yaco, 24 Aug. 1933.

Tree 10-30 m tall, 10-50 cm diam; young twigs sparsely covered with appressed hairs, soon glabrous. Leaves: petiole 2-5 mm long, 1-3 mm diam; lamina narrowly ovate to narrowly obovate, $9-22$ by $3-8 \mathrm{~cm}$ (leaf index $2.6-3.3$ ), coriaceous, not verruculose, shiny and greyish green to brown above, greyish green to brown below, but primary vein reddish brown, glabrous above, sparsely covered with appressed hairs below, base acute to obtuse, often slightly oblique, apex acuminate (acumen 10-20 mm long), primary vein raised above, secondary veins distinct, 8-14 on either side of primary vein, raised above, angle of secondary veins with primary vein $45-65^{\circ}$, smallest distance between loops and margin 2-6 mm, tertiary veins raised above, reticulate. Flowers in up to 10 -flowered inflorescences; pedicels 3-6 mm long, 0.5-1 mm diam, fruiting pedicels $7-10 \mathrm{~mm}$ long, $1.5-2 \mathrm{~mm}$ diam, sparsely covered with appressed hairs to glabrous; bracts 4-6, depressed ovate, 1-1.5 mm long, outer side densely to rather densely covered with appressed hairs; flower buds subglobose; sepals broadly to shallowly ovate-triangular, $1-3$ by $1.5-3 \mathrm{~mm}$, outer side rather densely to sparsely covered with appressed hairs; petals white, yellow to cream in vivo, elliptic, $6-8$ by $3-4 \mathrm{~mm}$, outer side rather densely covered with appressed hairs to glabrous; stamens c. 20, 2-3 mm long, apex of connective narrowly triangular; carpels $\leq 10$. Monocarps $1-10$, green, maturing yellowish to red in vivo, black in sicco, obovoid, ellipsoid, or globose, $11-23$ by $6-16 \mathrm{~mm}$, glabrous, apex rounded, wall $0.5-2 \mathrm{~mm}$ thick, stipes $1-2$ by $1-2 \mathrm{~mm}$. Seed ellipsoid to obovoid, 11-15 by $7-10 \mathrm{~mm}$, brown, surface transversely striate, ruminations spiniform or peg-shaped.

Distribution - Colombia (Amazonas, El Valle del Cauca), Brazil (Acre, Amazonas, Pará, Rondônia), Ecuador (Napo), Peru (Cusco, Huánuco, Loreto, Madre de Dios, San Martín).

Habitat \& Ecology - In non-inundated or periodically inundated (igapó or várzea) forest, on white sands, brown latosols or clayey soil. At elevations of $0-700 \mathrm{~m}$. Flowering: August to November; fruiting: all year through.

Vernacular names - Brazil: Envira-de-tambaquí (Daly et al. 9392), Envira-branco-do-igapó (Sothers \& Saraiva 23), Enviraferro (Daly et al. 8241, 10982, Silveira et al. 985), Envira-preta (Daly et al. 10271, Oliveira et al. 766), Gogó-de-guariba (Silveira 

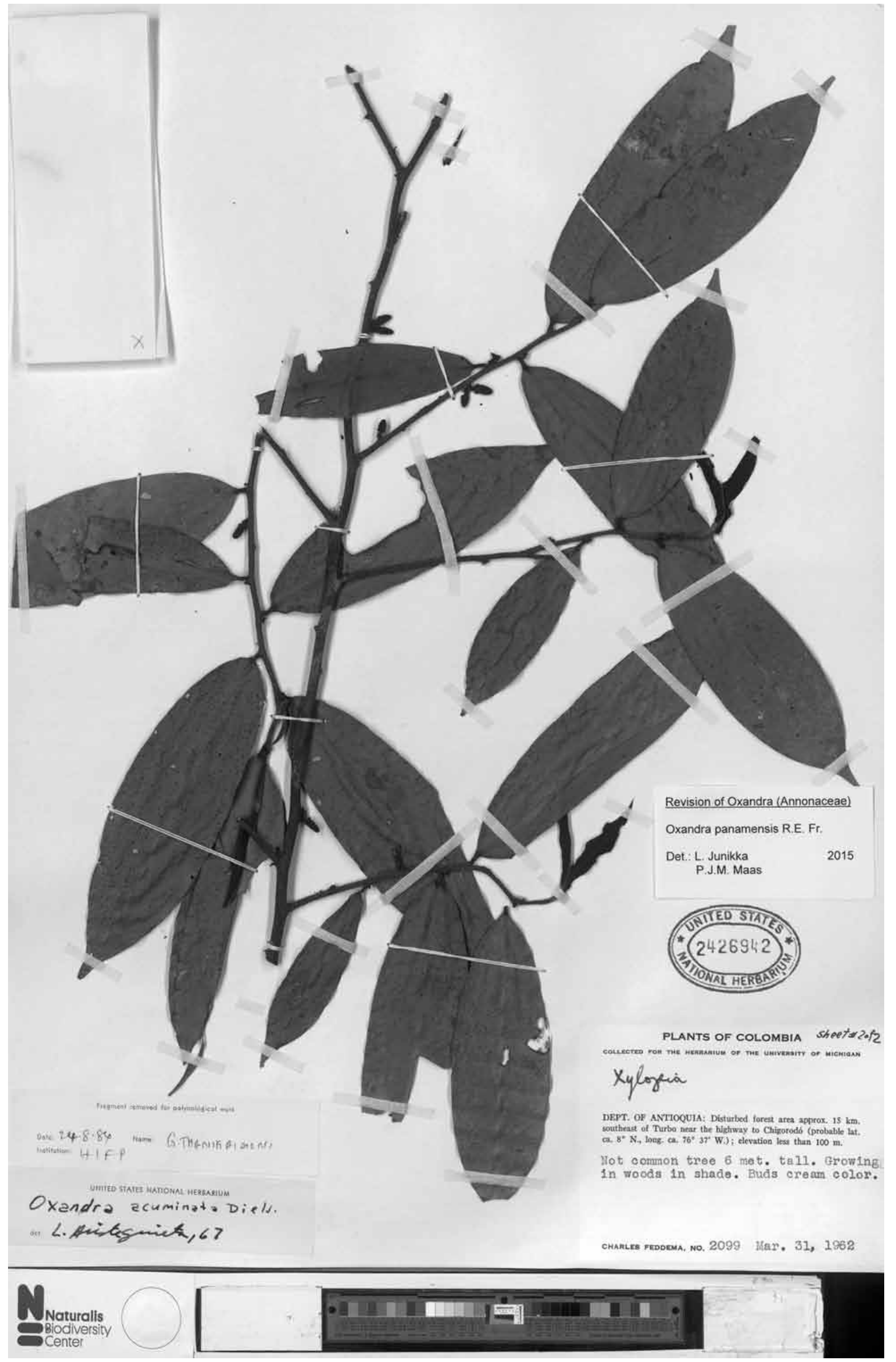

Fig. 17 Oxandra panamensis R.E.Fr. Flowering twig (Feddema 2099, US). 


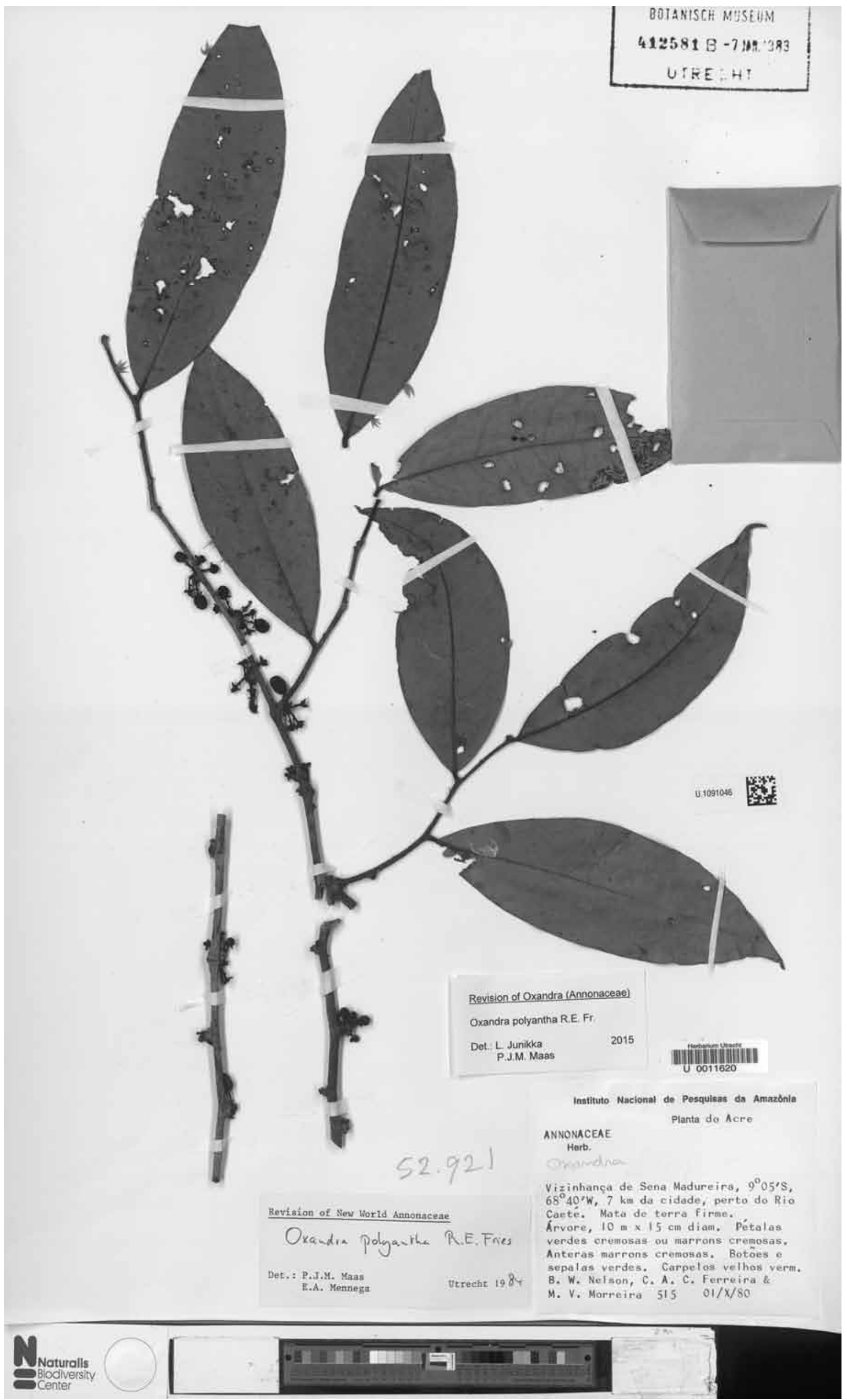

Fig. 18 Oxandra polyantha R.E.Fr. Flowering twig (Nelson et al. 515, U). 
1039). Colombia: Cajao dujecu (Muinane name), Carguero de sabana, Dogui-có (Miraña name). Peru: Espintana (Rimachi Y. 3045), Misa (Bell \& Phillips 88-189), Paujil micuna (McDaniel 16244), Sacha aceituna (Schunke V. 4739), Tortuga (Ellenberg 2953).

Uses - Used in construction (Bell \& Phillips 88-189, Peru); con el tronco se elaboran vigas para construir viviendas y los frutos son utilizados como carnada para pescar (Colombia: Sánchez Sáenz 1997); fruto comestível (Silveira et al. 1039, Brazil).

Notes - Oxandra polyantha is one of the two South American species in the genus with many-flowered inflorescences, the other one being $O$. riedeliana.

It differs markedly from $O$. riedeliana by much thicker (coriaceous instead of chartaceous) leaves, which have a reddish brown primary vein at the lower side. Furthermore, the leaves and young twigs of this species are sparsely covered with appressed hairs, whereas these of $O$. riedeliana are completely glabrous. In O. polyantha the leaf base is often obtuse, but in $O$. riedeliana acute to attenuate.

\section{Oxandra reticulata Maas - Map 9}

Oxandra reticulata Maas in Maas et al. (1986) 261, f. 9, 10b, 11a-d. - Type: Schatz et al. 842 (holo U; iso F, K, MO, NY, US), Brazil, Maranhão, between Cachoerinha and Igarapé Pau Grosso, 57 km SSW of Barra do Corda, 3 Mar. 1983

Shrub or tree 1-12 m tall, 5-10 cm diam; young twigs glabrous. Leaves: petiole $2-5 \mathrm{~mm}$ long, $0.5-1 \mathrm{~mm}$ diam; lamina elliptic to narrowly ovate, $3-10$ by $1-5 \mathrm{~cm}$ (leaf index $1.7-2.8$ ), coriaceous, not verruculose, often reddish brown-punctate below, shiny and brownish green to greyish green above, somewhat paler and sometimes glaucous below, glabrous above and below, base cordate to obtuse, apex bluntly acute to emarginate, primary vein slightly raised to flat above, secondary veins distinct, 7-12 on either side of primary vein, raised above, angle of secondary veins with primary vein $45-70^{\circ}$, smallest distance between loops and margin $1-3 \mathrm{~mm}$, tertiary veins distinctly raised above and below, reticulate. Flowers solitary; pedicels 3-4 $\mathrm{mm}$ long, c. $0.5 \mathrm{~mm}$ diam, fruiting pedicels $5-7$ $\mathrm{mm}$ long, c. $1 \mathrm{~mm}$ diam, sparsely covered with appressed hairs to glabrous; bracts 1-2, depressed ovate, c. $1 \mathrm{~mm}$ long, outer side densely to sparsely covered with appressed hairs; flower buds ellipsoid to globose; sepals broadly to shallowly ovate-

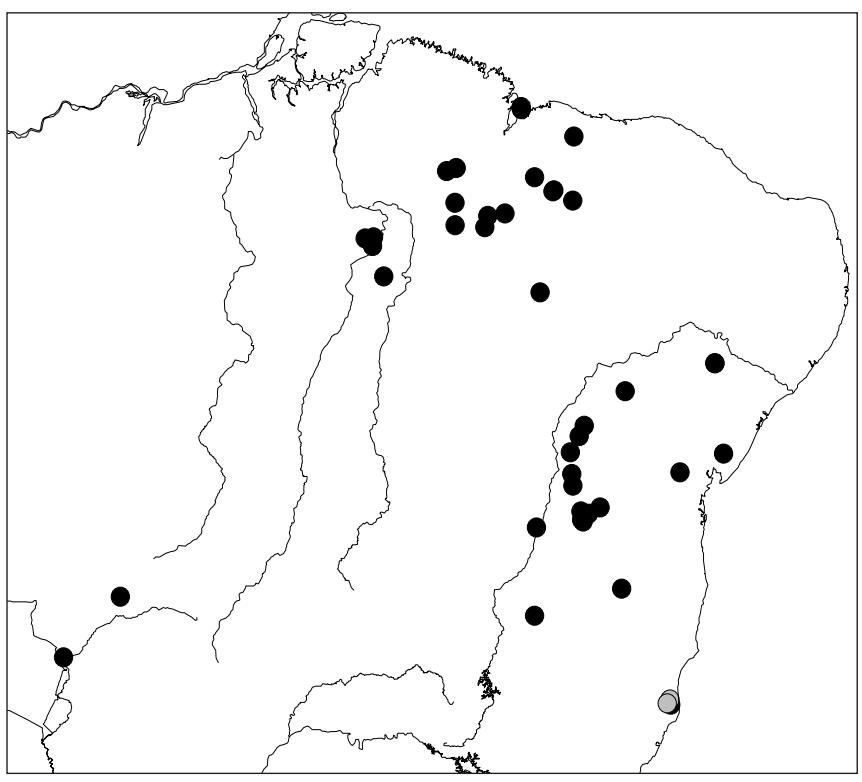

Map 9 Distribution of Oxandra reticulata $(\bullet)$ and O. unibracteata $(\bigcirc)$. triangular, $1-3$ by $1.5-3 \mathrm{~mm}$, outer side sparsely covered with appressed hairs or glabrous; petals white to greenish yellow in vivo, elliptic or obovate to narrowly so, $5-8$ by $2-3 \mathrm{~mm}$, outer side glabrous; stamens c. $10,2.5-3 \mathrm{~mm}$ long, apex of connective narrowly triangular; carpels $\leq 5$. Monocarps $1-4$, glaucous, green, maturing orange to red in vivo, black in sicco, broadly ellipsoid to ellipsoid, $13-28$ by $8-17 \mathrm{~mm}$, glabrous, apex apiculate (apiculum $0.1-0.5 \mathrm{~mm}$ long) or rounded, wall $0.2-1 \mathrm{~mm}$ thick, stipes $1-4$ by $1-2 \mathrm{~mm}$. Seed ellipsoid, 13-19 by $7-13 \mathrm{~mm}$, pale brown, surface transversely striate, ruminations lamellate in 4 parts.

Distribution - Brazil (Bahia, Espírito Santo, Maranhão, Mato Grosso, Minas Gerais, Pará, Piauí, Tocantins).

Habitat \& Ecology - In caatinga, campo rupestre, cerrado, cerradão, dry forest, on sandy or rocky soil. At elevations of 0-1100 m. Flowering: March, October, December; fruiting: January to April.

Vernacular names - Brazil: Atinha (Fróes 11578), Imbiúmineiro (Da Luz 1).

Note - Oxandra reticulata, restricted to dry vegetation types of $E$ and SE Brazil, is aberrant from all other species by very small leaves, distinctly reticulate on both sides. The primary vein and margins on the lower side of the lamina, moreover, are often densely covered with reddish to black dots.

19. Oxandra rheophytica Maas \& Junikka, sp. nov. — Fig. 19; Map 10

Ab omnibus speciebus foliis linearibus differt. - Typus: Callejas et al. 9343 (holo U; iso HUA), Colombia, Antioquia, Mun. Puerto Berrío, Vereda Bodegas, sitio San Juan de Bedout, Quebrada de San Juan, 300 m, 4 Mar. 1990.

Shrub 2-3 m tall; young twigs glabrous, grooved. Leaves: petiole $1-3 \mathrm{~mm}$ long, $1 \mathrm{~mm}$ diam; lamina linear, $7-11$ by $1-1.5$ $\mathrm{cm}$ (leaf index 9-10), chartaceous, sparsely, but distinctly verruculose below, dull and greyish above, brown below, glabrous above and below, base obtuse, oblique, apex long-acute, primary vein raised above, secondary veins indistinct, 12-15 on either side of primary vein, slightly raised above, angle of secondary veins with primary vein $50-70^{\circ}$, smallest distance between loops and margin c. $1 \mathrm{~mm}$, tertiary veins flat above, reticulate. Flowers solitary; pedicels $1-2 \mathrm{~mm}$ long, $1 \mathrm{~mm}$ diam, glabrous; bracts 4-5, depressed ovate, 1-1.5 mm long, outer side glabrous; flower buds globose; sepals broadly ovate, c. 2 by $2 \mathrm{~mm}$, outer side glabrous; petals colour in vivo not recorded, oblong-elliptic, c. 6 by $4 \mathrm{~mm}$, outer side glabrous; stamens c. 25 , 1-1.5 mm long, apex of connective depressed ovate; carpels $\leq 5$. Monocarps (immature) c. 5, green, black in sicco, ellipsoid, $7-8$ by $4-5 \mathrm{~mm}$, glabrous, apex rounded, wall not measurable, stipes absent. Seed not seen.

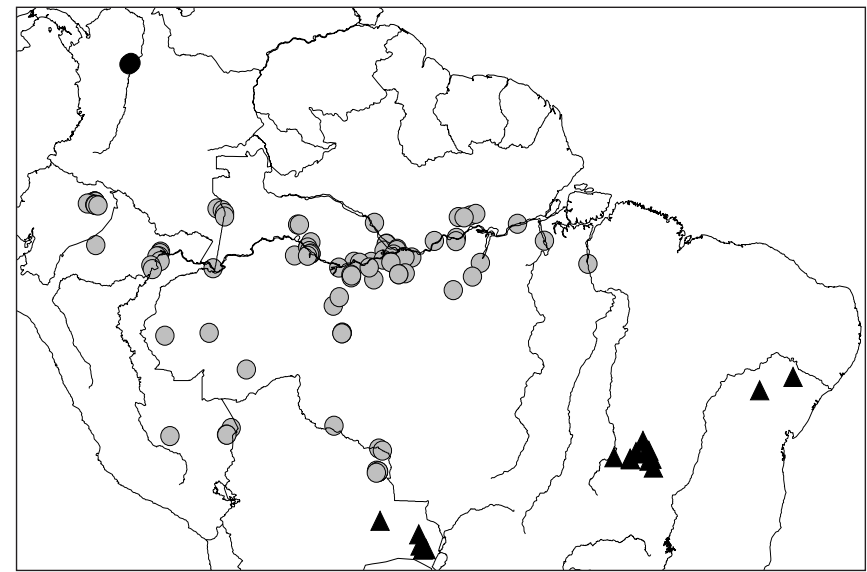

Map 10 Distribution of Oxandra rheophytica $(\bullet)$, O. riedeliana $(\bigcirc)$ and O. saxicola $(\mathbf{\Delta})$. 


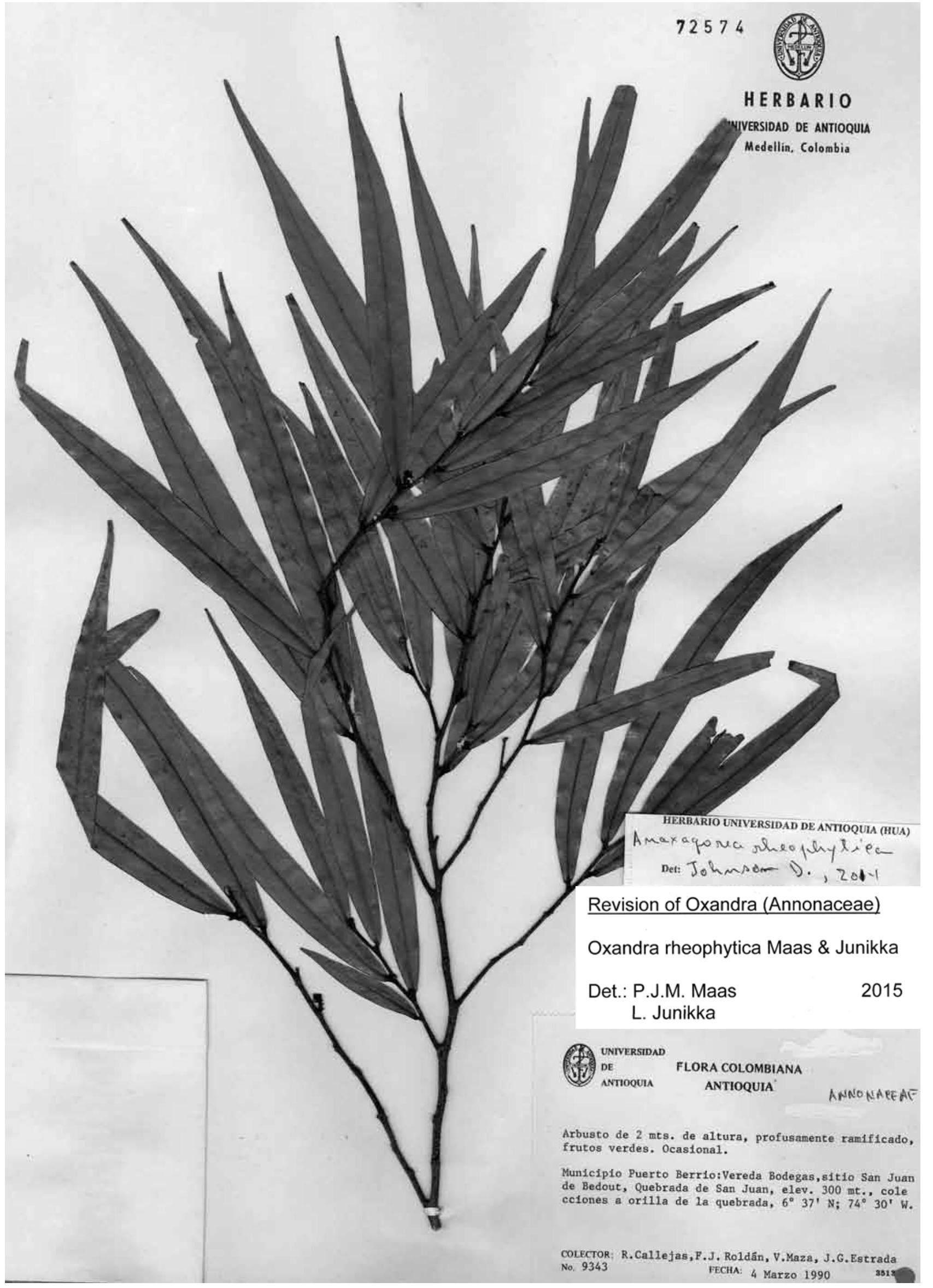

Fig. 19 Oxandra rheophytica Maas \& Junikka. Flowering twig (Callejas et al. 9343, iso HUA). 


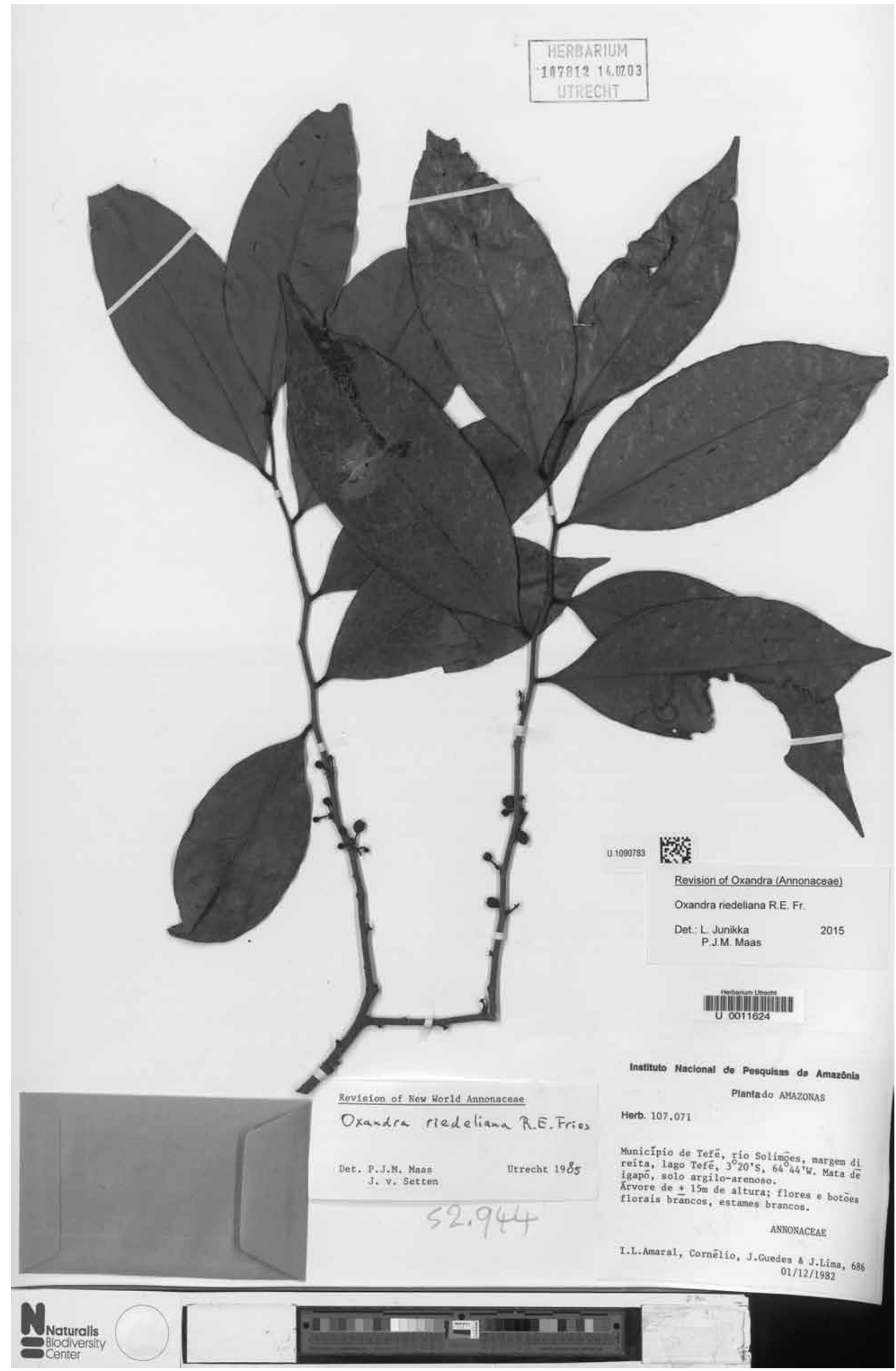

Fig. 20 Oxandra riedeliana R.E.Fr. Flowering twig (Amaral et al. 686, U). 
Distribution - Colombia (Antioquia).

Habitat \& Ecology — In humid, periodically inundated forest. At elevations of 150-300 m. Flowering: March; fruiting: October.

Other specimen studied. ColombiA, Antioquia, Mun. Puerto Berrío, via Puerto Berrio-Yondó, 3.5 km NE of Puerto Berrio, sitio Bodegas, Quebrada San Juan de Bedout, 150 m, Callejas \& Cardona 12558 (HUA).

Note - Oxandra rheophytica has extremely narrow, linear leaves and matches $O$. xylopioides in that aspect. It differs, however, by the leaf base which lacks the tooth-like prolongations of $O$. xylopioides and by the sparse presence (instead of very dense) of verruculae on the leaves. The epithet 'rheophytica' refers to the habitat in borders of streams (Greek $\rho \varepsilon ́ o \varsigma=$ stream; wútov = plant).

\section{Oxandra riedeliana R.E.Fr. - Fig. 20, 21a, b; Map 10}

Oxandra riedeliana R.E.Fr. (1906) 2, f. 7-9. - Type: Riedel 1389 (holo S; iso K, M, MPU), Brazil, Amazonas, Borba, Aug. 1828

Tree 3-30 m tall, 10-28 cm diam; young twigs glabrous. Leaves: petiole 2-5 $\mathrm{mm}$ long, 1-2 $\mathrm{mm}$ diam; lamina narrowly rhombic, narrowly ovate or narrowly obovate, $6-17$ by $2-6 \mathrm{~cm}$ (leaf index 2.5-3.1), chartaceous, not verruculose, shiny and greyish green to greyish brown above, brownish below, glabrous above and below, base acute to attenuate, apex acuminate (acumen 5-15 mm long) to acute, primary vein raised above, secondary veins distinct, 7-12 on either side of primary vein, raised above, angle of secondary veins with primary vein $45-80^{\circ}$, smallest distance between loops and margin 2-3 $\mathrm{mm}$, tertiary veins slightly raised above, reticulate. Flowers in 1-12-flowered inflorescences; pedicels 2-6 mm long, 0.5-1 $\mathrm{mm}$ diam, fruiting pedicels $5-7 \mathrm{~mm}$ long, $1-1.5 \mathrm{~mm}$ diam, rather densely to sparsely covered with appressed hairs; bracts 5-6, depressed ovate, $0.5-1 \mathrm{~mm}$ long, outer side sparsely covered with appressed hairs; flower buds globose; sepals shallowly to broadly ovate-triangular, $1-1.5$ by $1-2 \mathrm{~mm}$, outer side sparsely covered with appressed hairs to glabrous; petals white to yellow in vivo, elliptic to obovate, $6-7$ by $2-5 \mathrm{~mm}$, outer side glabrous; stamens 11-18, 2-3 mm long, apex of connective narrowly triangular to narrowly ovate; carpels $\leq 7$. Monocarps $1-6$, green, maturing dark red in vivo, black in sicco, globose to broadly ellipsoid, $12-18$ by $11-16 \mathrm{~mm}$, glabrous, apex rounded, wall $0.5-3 \mathrm{~mm}$ thick, stipes $1-2$ by $1-2 \mathrm{~mm}$. Seed globose or ellipsoid, $9-12$ by $8-11 \mathrm{~mm}$, pale brown to cream, surface transversely striate, ruminations spiniform.

Distribution - Colombia (Amazonas, Vaupés), Brazil (Acre, Amazonas, Pará, Rondônia, Roraima), Ecuador (Napo, Orellana, Pastaza), Peru (Cusco, Loreto, Madre de Dios), Bolivia (Santa Cruz).

Habitat \& Ecology — In non-inundated or often periodically inundated (igapó, tahuampa, várzea) forest or open swamp forest, on sandy to clayey soil. At elevations of 0-700 m. Flowering: Mainly between July and December; fruiting: October to June.

Vernacular names - Bolivia: Singa colorada (P.F. Foster et al. 357, 439). Brazil: Envira (Gottsberger \& Döring 14-19186, Luize 270, 296, M. Silva 753), Envira-de-tambaquí (D. Coêlho et al. INPA 81953, Souza et al. 156, 157), Envira-de-várzea (Pardo et al. 54), Envira-preta-desconhecida (Rosa et al. 5325), Envira-preta-folha-media (Rosa et al. 5661), Envira-surucucu (Barbieri 24), Envireira-branca (Souza 150), Juvueira-algodão (Capucho 448). Ecuador: Pantomo (Huaorani name, Freire \& Naranjo 709, Naranjo \& Freire 371).

Uses - Envira usada para amaração em geral e a madeira para lenha (Silveira et al. 985, Brazil).

Field observations — Fruit edible (Freire \& Naranjo 709, Naranjo \& Freire 371 , Ecuador).
Note - Oxandra riedeliana shares with O. polyantha a manyflowered inflorescence. For the differences between both species see under $O$. polyantha.

\section{Oxandra saxicola Maas \& Junikka, sp. nov. — Plate $2 c-e$; Map 10}

Floribus subsessilibus (saepe in axillis foliorum delapsorum apparentibus), monocarpiis globosis 20-25 mm in diametro metientibus differt. - Typus: Parada 944 (WAG 3 sheets; iso MO), Bolivia, Santa Cruz, German Busch, 500 m from El Carmen Viejo, 165 m, 13 May 2008.

Tree or shrub, $0.5-12 \mathrm{~m}$ tall, $20-50 \mathrm{~cm}$ diam; young twigs densely lenticellate, sparsely (Bolivia) to densely (Brazil) covered with erect hairs, soon glabrous. Leaves: petiole $2-4 \mathrm{~mm}$ long, c. $1 \mathrm{~mm}$ diam; lamina narrowly elliptic to ovate, $5-10$ by $2.5-5 \mathrm{~cm}$ (leaf index 1.6-2.5), coriaceous, not verruculose, shiny and green above, pale glaucous green below, glabrous (Bolivian material) to sparsely covered with appressed hairs (Brazilian material) above, sparsely covered with appressed hairs to glabrous (Bolivian material) or rather densely to sparsely covered with erect hairs (Brazilian material) below, base obtuse to cordate, apex obtuse to bluntly acute, primary vein slightly raised to flat above, secondary veins distinct, 10-12 on either side of primary vein, raised above, angle of secondary veins with primary vein $40-70^{\circ}$, smallest distance between loops and margin 1-3 $\mathrm{mm}$, tertiary veins strongly raised above and below, reticulate. Flowers solitary, often on leafless branchlets; pedicels $0.5-1 \mathrm{~mm}$ long, c. $1 \mathrm{~mm}$ diam, fruiting pedicels c. $3 \mathrm{~mm}$ long, c. $2 \mathrm{~mm}$ diam, rather densely covered with appressed hairs; bracts $5-7$, broadly ovate 1-2.5 $\mathrm{mm}$ long, lowest bract sparsely covered with appressed hairs to glabrous, the other bracts densely covered with appressed, whitish hairs; flower buds subglobose; sepals broadly ovatetriangular, $2-2.5$ by $1.5-3 \mathrm{~mm}$, outer side densely covered with appressed, whitish hairs (Brazil) to glabrous (Bolivia); petals yellowish white to greenish white in vivo, narrowly elliptic, 5-7 by $1-3 \mathrm{~mm}$, outer side glabrous; stamens c. $20,2.5-3 \mathrm{~mm}$ long, apex of connective ovate to depressed ovate; carpels $5-10$. Monocarps 1-3, green to yellow, maturing yellow to red in vivo, blackish brown in sicco, somewhat glaucous when young, subglobose, $20-25$ by $20-25 \mathrm{~mm}$, glabrous, apex rounded, wall c. $3 \mathrm{~mm}$ thick, stipes absent. Seed subglobose, 13-25 by 10-15 mm, brown, surface transversely striate, ruminations peg-shaped to lamellate in 4 parts.

Distribution - Bolivia (Santa Cruz), Brazil (Bahia, Goiás, Mato Grosso do Sul, Tocantins).

Habitat \& Ecology — In 'bosque seco chiquitano', in 'vegetación saxícola' (Bolivia) and: cerrado, on rocky soil, also in deciduous rainforest on rocky soil (Brazil). At elevations of $100-$ 800 m. Flowering: February, May, October, November; fruiting: March to May, October to January.

Vernacular name - Brazil: Mejo-de-porco (Ratter et al. 7327).

Field observations - Flores muy aromáticas (Parada 944, 969, Bolivia); flores con olor de limão (Pereira \& Amaral 326, Brazil).

Selection of other specimens studied. BolIvIA, Santa Cruz, Prov. Chiquitos, Concesión Don Mario, c. 125 km NE of San José de Chiquitos, 450 m, Mamani et al. 1408 (MO); Angel Sandoval, $9 \mathrm{~km}$ de Santo Corazón, sobre el camino a Santiago de Chiquitos, 263 m, Wood et al. 25096 (K, UB); German Busch, Carmén Rivero Torre, $0.5 \mathrm{~km}$ de la carretera entrando hacia $\mathrm{El}$ Carmén Viejo, 120 m, Wood \& Villarroel 25544 (K, L, UB). - BRAZIL, Bahia, Paulo Alfonso, Estação Ecológica Raso de Catarina (Mata da Pororoca), 715 m, Moraes et al. 102 (MO, U); Campo Formoso, Orlandi 379 (HUEFS, MG, RB). Goiás, Mun. Nova Roma, saída da cidade em direção a laciara Fazenda Cachoeira, 710 m, Alvarenga et al. 1292 (CEN); Mun. Posse, Rodovia Brasília-Fortaleza, 220 km de Formosa, Belém \& Mendes 116 (IAN, MG); Mun. Minaçu, right bank of Rio Tocantins, Bucci \& Verano 1579A, 1580A (UB); Porto Real, Burchell 8464 (K); Mun. Monte Alegre, Fazenda Nica, 565 m, Fonseca et al. 2987 (IBGE); Mun. Guarani de Goiás, 800 m, Pereira \& 
Alvarenga 2999 (IBGE); Mun. São Domingos, km 34 da estrada Guaraní de Goiás/Terra Ronca, 600 m, Pereira \& Alvarenga 3288 (RB); Mun. Mambaí, Vale do Rio Paranã, tributary of Lower Rio Tocantins, left margin of Rio Vermelho, affluent of Rio Corrente, Pereira \& Alvarenga 3641 (IBGE, MG); Mun. Cavalcante, Bahia Morro Branco (Rio Tocantins), vila Veneno, 320 m, Pereira-Silva et al. 5664 (CEN); 18 km from Alto de Paraíso de Goiás on the road to Nova Roma, Ratter et al. 7327 (K); Mun. Colinas do Sul, Serra da Mesa (Grande Lago), 350 m, Walter et al. 3583 (CEN, UFG). Mato Grosso do Sul, Dois Irmãos do Buriti, Fazenda Taruana, 260 m, Solórzano 215 (UB). Tocantins, Mun. Aguiarnópolis, Patio da Ferrovia Norte e Sul, 155 m
Pereira \& Amaral 326 (CEN); Mun. Taguatinga de Tocantins, Azuis, Rio Sobrado, Pereira 3467 (IBGE); Mun. Paranã, Fazenda São João, 342 m, Sevilha et al. 3779 (CEN).

Notes - Oxandra saxicola resembles $O$. reticulata by its leaf shape and size and leaf reticulation, but can be told apart by subsessile flowers (flowering pedicels $0.5-1 \mathrm{~mm}$ long vs $3-4$ $\mathrm{mm}$ long), a higher number of bracts (5-7 vs 1-2) and globose, large, thick-walled monocarps instead of ellipsoid, thin-walled monocarps.
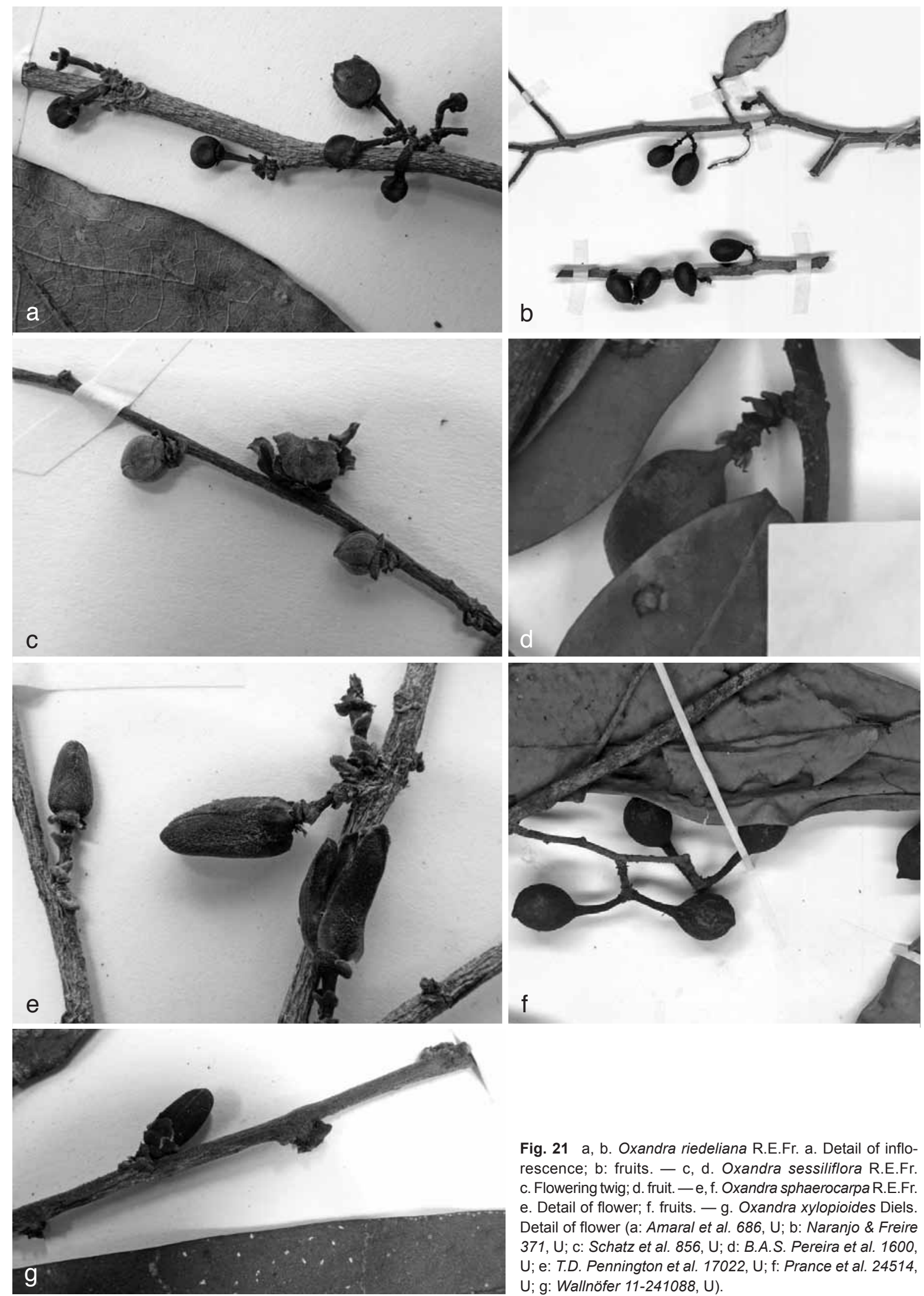

Fig. 21 a, b. Oxandra riedeliana R.E.Fr. a. Detail of inflorescence; b: fruits. - c, d. Oxandra sessiliflora R.E.Fr. c. Flowering twig; d. fruit. - e, f. Oxandra sphaerocarpa R.E.Fr. e. Detail of flower; f. fruits. - g. Oxandra xylopioides Diels. Detail of flower (a: Amaral et al. 686, U; b: Naranjo \& Freire 371, U; c: Schatz et al. 856, U; d: B.A.S. Pereira et al. 1600 , U; e: T.D. Pennington et al. 17022, U; f: Prance et al. 24514, U; g: Wallnöfer 11-241088, U). 
A peculiarity of this species is the fact that flowers are often produced in leafless condition.

The Brazilian collections look quite similar to the Bolivian specimens aberrant, however, in having a different indument of young twigs and leaves and hairy (instead of glabrous) sepals.

\section{Oxandra sessiliflora R.E.Fr. - Fig. 21c, d, 22; Map 11}

Oxandra sessiliflora R.E.Fr. (1931) 172, f. 5f, g. - Type: Ducke RB 18347 (holo S), Brazil, Pará, Rio Tocantins, near Campina de Arumaténa, 3 Jan. 1915.

Tree or shrub 1-25 m tall, 8-20 cm diam; young twigs rather densely covered with appressed hairs, soon glabrous. Leaves: petiole $2-3 \mathrm{~mm}$ long, $0.5-1 \mathrm{~mm}$ diam; lamina narrowly ovate to narrowly obovate, $3-7.5$ by $1-2.5 \mathrm{~cm}$ (leaf index $2.4-3.4$ ), coriaceous, not verruculose, smooth, shiny and dark brown to brownish green above, brown to brownish green below, glabrous above, rather densely to sparsely covered with appressed hairs 1-2 mm long below, base obtuse to slightly cordate, apex bluntly acute, sometimes slightly emarginate, primary vein flat to slightly impressed above, secondary veins distinct, 8-12 on either side of primary vein, raised above, angle of secondary veins with primary vein $45-65^{\circ}$, smallest distance between loops and margin 1-2 $\mathrm{mm}$, tertiary veins raised above, reticulate. Flowers in 1-2-flowered inflorescences; flowering and fruiting pedicels 1-4 $\mathrm{mm}$ long, c. $1 \mathrm{~mm}$ diam, densely covered with appressed hairs; bracts 4-5, depressed ovate, 1-1.5 mm long, outer side densely covered with appressed hairs; flower buds globose; sepals shallowly to broadly ovate-triangular, c. 2 by $1.5-2.5 \mathrm{~mm}$, outer side rather densely covered with appressed hairs; petals white to pinkish white in vivo, ovate, 3-7 by $2-5 \mathrm{~mm}$, outer (and also inner) side rather densely covered with appressed hairs; stamens c. 30, 2-3 mm long, apex of connective narrowly triangular to narrowly oblong; carpels $\leq 8$. Monocarps 1-7, green, maturing reddish black in vivo, black to brown in sicco, ellipsoid, $9-13$ by $6-9 \mathrm{~mm}$, sparsely covered with appressed hairs, apex apiculate (apiculum to c. $1 \mathrm{~mm}$ long), wall $0.2-0.5 \mathrm{~mm}$ thick, stipes $1-2$ by $1 \mathrm{~mm}$. Seed ellipsoid to oblongoid, or obovoid, $9-13$ by $5-8 \mathrm{~mm}$, pale reddish brown, surface transversely striate, ruminations composed of flattened pegs or lamellate in 4 parts.

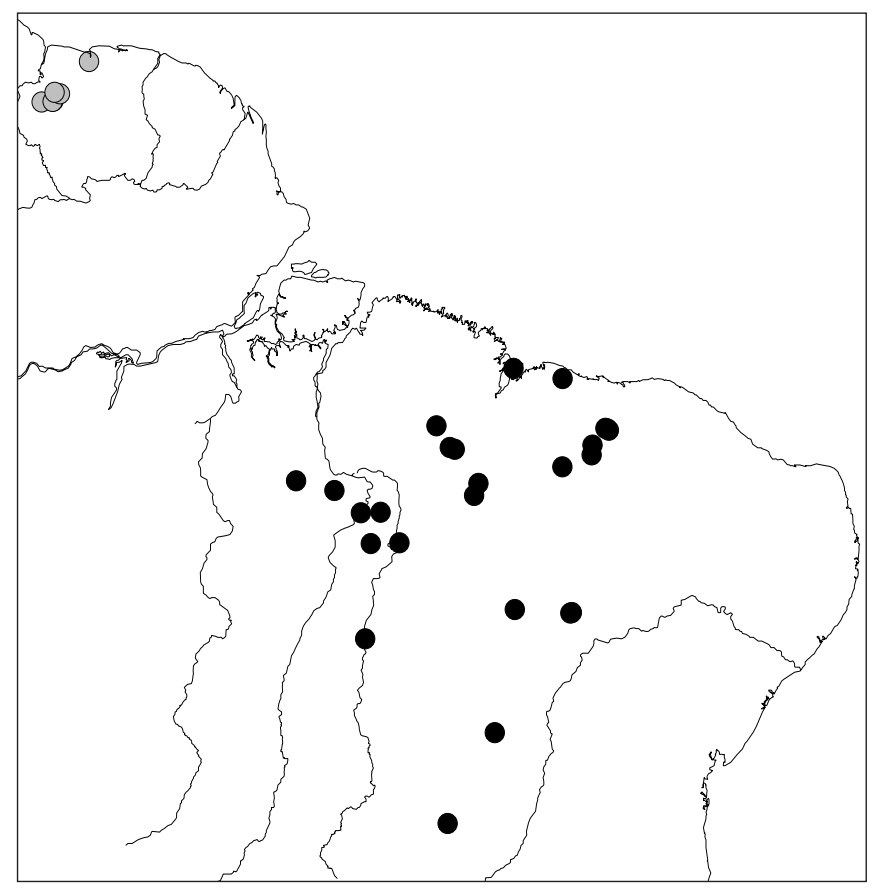

Map 11 Distribution of Oxandra sessiliflora $(\bullet)$ and O. surinamensis $(\bigcirc)$.
Distribution — Brazil (Bahia, Ceará, Maranhão, Pará, Paraíba, Piauí, Rio de Janeiro, Tocantins).

Habitat \& Ecology - In dry vegetations like caatinga, cerrado, sometimes in forest on terra firme, on sandy soil. At elevations of $0-360 \mathrm{~m}$. Flowering: January to April; fruiting: March to May.

Vernacular name - Brazil: Cundurú (Barroso \& Guimaraes 23, Chaves 1133415, Emperaire 2214, 2214A, 2236).

Uses - Wood used ('Madeireira') (Chaves 1133415, Brazil).

Field observations - Flowers very fragrant, reminiscent of lemon (Schatz et al. 815, 856, Brazil); wood bleeding red (Schatz et al. 857, 906, 941, Brazil).

Note - Oxandra sessiliflora, confined to SE and E Brazil, is one of the most easily distinguishable species by its very small, shiny, acutely tipped leaves, almost sessile flowers, and by the presence of a rather dense indument on both young twigs and petals. It is different from the similar-looking $O$. reticulata by the number of bracts (4-5 vs 1-2), flat to slightly impressed primary vein (vs slightly raised to flat in $O$. reticulata), and the presence of indument on both young twigs and petals.

\section{Oxandra sphaerocarpa R.E.Fr. - Fig. 21e, f, 23; Map 12}

Oxandra sphaerocarpa R.E.Fr. (1934) 198. - Type: LI. Williams 475 (holo F), Peru, Loreto, Lower Río Nanay, S bank of Río Amazonas, 28 May 1929.

Tree 6-40 m tall, 10-50 cm diam ('with low plank buttresses', Daly et al. 5621); young twigs rather densely covered with appressed hairs, soon glabrous. Leaves: petiole 2-4 mm long, 1-2 mm diam; lamina narrowly elliptic to narrowly ovate, $8-20$ by $3-7 \mathrm{~cm}$ (leaf index $2.7-3.8$ ), chartaceous, rather densely verruculose to not verruculose above and below, dull and brown to brownish grey green above, pale brown to brown below, mostly densely covered with appressed to erect hairs along primary vein above, sparsely covered with appressed hairs below, base acute to obtuse, often oblique and sometimes with two angular to tooth-like projections on either side, apex acute to acuminate (acumen 10-15 mm long), primary vein impressed to flat above, secondary veins distinct, $12-16$ on either side of primary vein, slightly raised above, angle of secondary veins with primary vein $65-80^{\circ}$, smallest distance between loops and margin $2-5 \mathrm{~mm}$, tertiary veins slightly raised above, reticulate. Flowers in 1-3-flowered inflorescences; flowering pedicels 2-6 $\mathrm{mm}$ long, 0.5-1 $\mathrm{mm}$ diam, fruiting pedicels 4-9 mm long, 1-3 $\mathrm{mm}$ diam, sparsely covered with appressed hairs to glabrous; bracts 4-6, depressed ovate, 1-2 mm long, outer side densely to rather densely covered with appressed hairs; flower buds

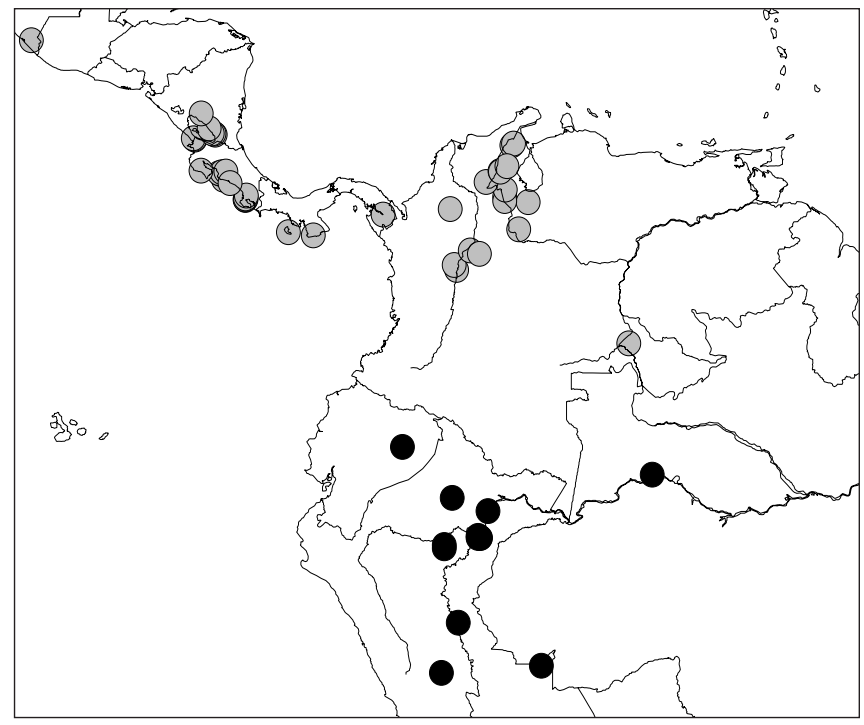

Map 12 Distribution of Oxandra sphaerocarpa ( $)$ and O. venezuelana (0). 


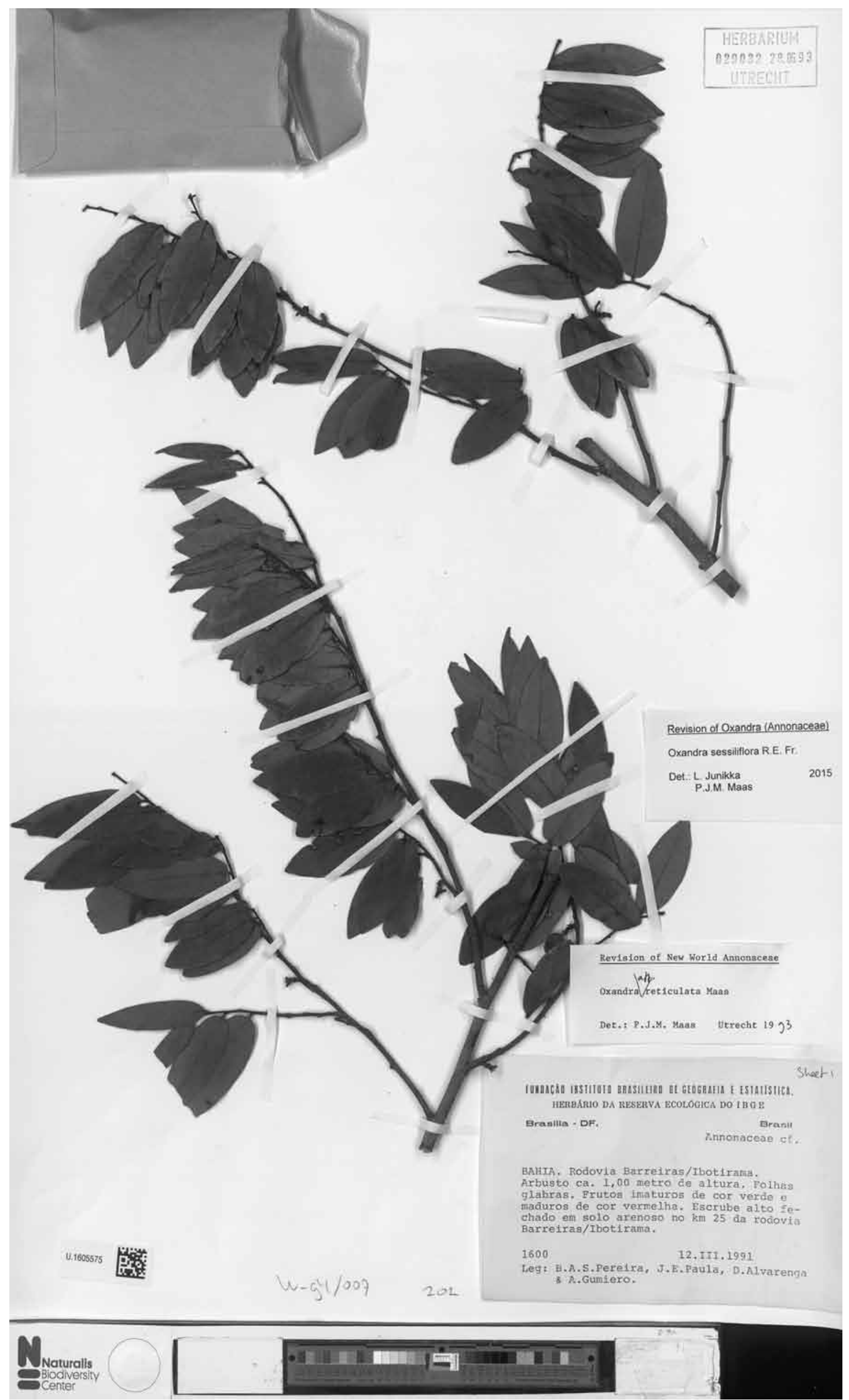

Fig. 22 Oxandra sessiliflora R.E.Fr. Fruiting twig (B.A.S. Pereira et al. 1600, U). 


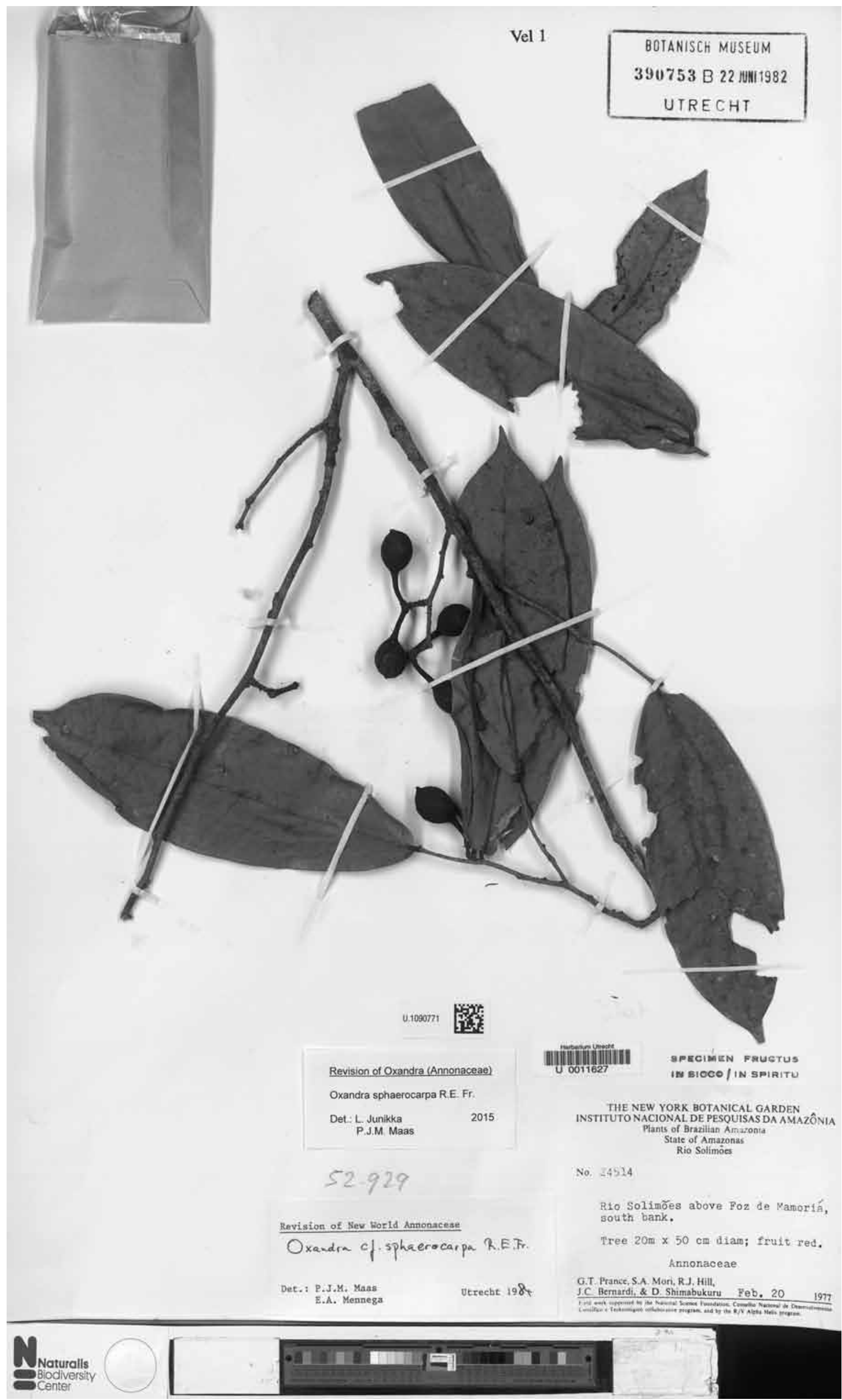

Fig. 23 Oxandra sphaerocarpa R.E.Fr. Fruiting twig (Prance et al. 24514, U). 


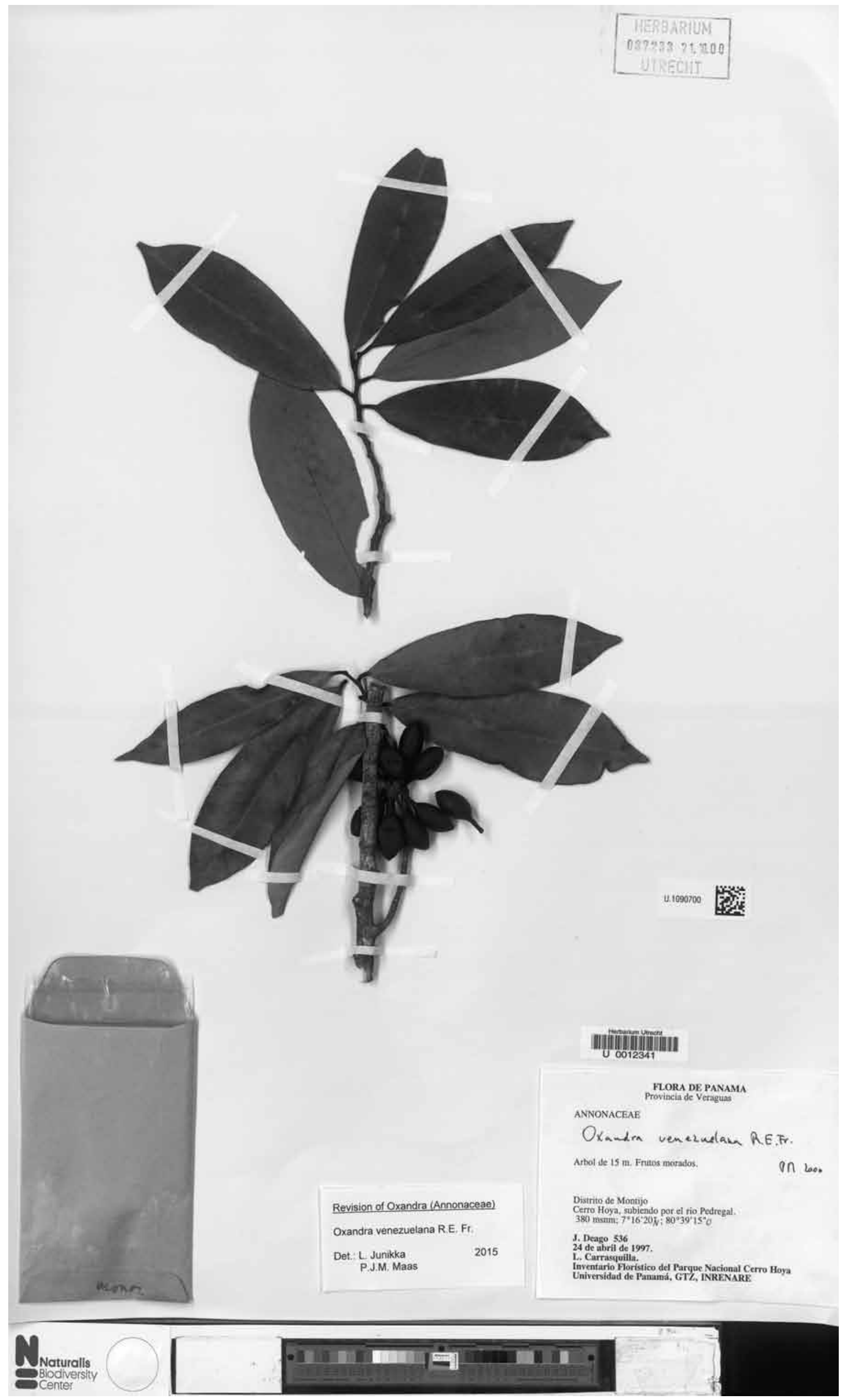

Fig. 24 Oxandra venezuelana R.E.Fr. Fruiting twig (Deago \& Carrasquilla 536, U). 
ellipsoid; sepals broadly to shallowly ovate-triangular, 1-1.5 by $1-3 \mathrm{~mm}$, outer side rather densely covered with appressed hairs; petals pale cream to cream, oblong-elliptic, $4-10$ by $2-5$ $\mathrm{mm}$, outer side rather densely covered with appressed hairs; stamens 15-20, 2.5-3 mm long, apex of connective narrowly triangular; carpels $\leq 20$. Monocarps $2-15$, green to reddish yellow, maturing red, black to bluish black in vivo, black in sicco, globose, sometimes ellipsoid, $10-17$ by $10-13 \mathrm{~mm}$, glabrous, apex apiculate (apiculum to c. $1 \mathrm{~mm}$ long), wall c. $1 \mathrm{~mm}$ thick, stipes $6-16$ by $1 \mathrm{~mm}$. Seed broadly ellipsoid to ovoid, 9-12 by $7-10 \mathrm{~mm}$, brown to pale brown, surface minutely pitted to transversely striate, ruminations spiniform.

Distribution - Brazil (Amazonas), Ecuador (Pastaza), Peru (Loreto, Pasco, Ucayali).

Habitat \& Ecology - In periodically inundated (restinga, tahuampa, várzea) forest, at clayey soil. At elevations of up to c. 150 m. Flowering: October; fruiting: February to May, October, November.

Vernacular names - Peru: Acara-wasca (LI. Williams 475, 478), Espintana (Daly et al. 5068, Freitas 10, T.D. Pennington et al. 17022, Valcarcel 539-2), Espintana roja (Daly et al. 5621), Yahuayachi caspi (Rimachi Y. 271).

Field observations - Flowers sweet-scented (T.D. Pennington et al. 17022); frutos con aroma a limón (Zak 4190, Ecuador).

Note - Oxandra sphaerocarpa can be distinguished in fruit by extremely long stipes up to $16 \mathrm{~mm}$ long and in flower by elongate, ellipsoid buds and hairy petals. The primary vein of the leaves is often densely covered with appressed to erect hairs above.

\section{Oxandra surinamensis Jans.-Jac. - Plate $2 \mathrm{f}-\mathrm{h}$; Map 11}

Oxandra surinamensis Jans.-Jac. (1970) 338, pl. 2. - Type: Florschütz \& Maas 2419 (holo U; iso BM), Suriname, 1-2 km S of Kabalebo airstrip, 17 Dec. 1964.

Shrub or tree $0.5-3 \mathrm{~m}$ tall, diam not recorded; young twigs rather densely covered with erect and appressed, long-persisting hairs. Leaves: petiole 1-2 mm long, c. $1 \mathrm{~mm}$ diam; lamina narrowly elliptic to narrowly obovate, $8-13$ by $3-5 \mathrm{~cm}$ (leaf index 2.6-3), chartaceous, not verruculose, dull and brownish green above and below, glabrous above, sparsely covered with appressed hairs along primary vein below, base obtuse, slightly oblique, apex acuminate (acumen 5-15 mm long), primary vein raised above, secondary veins distinct, $7-12$ on either side of primary vein, slightly raised above, angle of secondary veins with primary vein $65-80^{\circ}$, smallest distance between loops and margin $2-3 \mathrm{~mm}$, tertiary veins raised above, reticulate. Flowers solitary; pedicels c. $1-2 \mathrm{~mm}$ long, c. $1 \mathrm{~mm}$ diam, fruiting pedicels to c. $3 \mathrm{~mm}$ long, $1-1.5 \mathrm{~mm}$ diam, sparsely covered with appressed hairs; bracts 2-4, depressed ovate, $0.5-1 \mathrm{~mm}$ long, outer side sparsely covered with appressed hairs; flower buds globose to ellipsoid-oblong; sepals broadly to shallowly ovate-triangular, c. 1 by $1-2 \mathrm{~mm}$, outer side rather densely to sparsely covered with appressed hairs; petals white in vivo, narrowly elliptic, $5-7$ by $2-3 \mathrm{~mm}$, outer side sparsely covered with appressed hairs to glabrous; stamens c. 10 , c. $1.5 \mathrm{~mm}$ long, apex of connective depressed ovate; carpels $\leq 6$. Monocarps $1-6$, green, maturing yellow with reddish blush to black in vivo, brown in sicco, globose to ellipsoid, $8-10$ by $5-8 \mathrm{~mm}$, glabrous, apex rounded to apiculate (apiculum $<0.5 \mathrm{~mm}$ long), wall c. $0.2 \mathrm{~mm}$ thick, stipes c. 1 by $1 \mathrm{~mm}$. Seed ellipsoid-oblongoid, c. 8 by $6 \mathrm{~mm}$, pale brown, surface transversely striate, ruminations spiniform.

Distribution - Suriname.

Habitat \& Ecology — In forest on banks of river or ridgetops. At elevations of 0-700 m. Flowering: August; fruiting: February, March, August, December.
Note - Oxandra surinamensis, restricted to Suriname, resembles another Guianan species, namely O. asbeckii, but differs by non-verruculose leaves, loops which are closer to the leaf margins $(2-3$ vs $3-5 \mathrm{~mm})$ and smaller monocarps $(8-10$ vs $15-30 \mathrm{~mm}$ long).

\section{Oxandra unibracteata J.C.Lopes, Junikka \& Mello-Silva - Map 9}

Oxandra unibracteata J.C.Lopes, Junikka \& Mello-Silva (2013) 25, f. 1, 2. - Type: I.A. Silva 272 (holo SPF; iso CVRD, MO, RB, U), Brazil, Espírito Santo, Linhares, Reserva Natural Vale, Estrada Flamengo km 11, 30 Nov. 1981.

Oxandra sp. 2 Junikka in Maas et al. (2001) 84.

Tree 16-25 m tall, $20-35 \mathrm{~cm}$ diam; young twigs glabrous. Leaves: petiole $2-5 \mathrm{~mm}$ long, c. $1 \mathrm{~mm}$ diam; lamina narrowly elliptic, $4-8$ by $1-3 \mathrm{~cm}$ (leaf index $2.6-3.8$ ), coriaceous, not verruculose, but reddish black punctate below, shiny and greyish green above, brownish green below, glabrous above and below, base acute to slightly attenuate, apex bluntly acute, primary vein slightly raised above, secondary veins distinct, $8-10$ on either side of primary vein, raised above, angle of secondary veins with primary vein $45-70^{\circ}$, smallest distance between loops and margin c. $1 \mathrm{~mm}$, tertiary veins distinctly raised above and below, reticulate. Flowers solitary; flowering and fruiting pedicels 10-14 mm long, 0.5-1 mm diam, glabrous, bract 1 , depressed ovate, c. $1 \mathrm{~mm}$ long, outer side glabrous; flower buds globose; sepals connate for up to half of their length broadly ovate-triangular, $1-1.5$ by $2 \mathrm{~mm}$, outer side glabrous; petals bright green in vivo, elliptic to circular, $4-5$ by $2-4 \mathrm{~mm}$, outer side glabrous; stamens c. 20 , c. $2 \mathrm{~mm}$ long, apex of connective quadrangular; carpels $\leq 5$. Monocarps $1-5$, greenish red in vivo, black in sicco, ellipsoid, $15-18$ by $11-13 \mathrm{~mm}$, glabrous, apex rounded, wall $0.5-0.7 \mathrm{~mm}$ thick, stipes $7-8$ by $1 \mathrm{~mm}$. Seed ellipsoid, $10-15$ by $10-11 \mathrm{~mm}$, brown, surface minutely pitted to transversely striate, ruminations lamellate in 4 parts.

Distribution - Brazil (Espírito Santo).

Habitat \& Ecology — In non-inundated, high Atlantic Forest. At elevations of $0-100 \mathrm{~m}$. Flowering: November; fruiting: May.

Vernacular name - Brazil: Imbiú-preto (Folli 545, I.A. Silva 272).

Notes - Oxandra unibracteata, only known from the type locality in the Brazilian state of Espírito Santo, is one of the most distinctive species in the genus by its long and glabrous pedicels, which are provided with only one bract! This is rather unusual for Oxandra, which commonly has 4 or more bracts. The only other species is the very similar $O$. reticulata which has 1-2 bracts and, moreover, shorter pedicels.

Other features are the completely glabrous leaves, which have a strong reticulation on both sides.

\section{Oxandra venezuelana R.E.Fr. - Fig. 24; Map 12}

Oxandra venezuelana R.E.Fr. (1960) 22. - Type: Bernardi 1923 (holo NY; iso BM, FI, K 2 sheets, S), Venezuela, Mérida, El Vigía, Caño Amarillo, 150-250 m, 5 Feb. 1955.

Tree 4-35(-50) $\mathrm{m}$ tall, $10-60 \mathrm{~cm}$ diam, sometimes with red to yellowish exudate; young twigs glabrous or sometimes in the youngest stage covered with some scattered, appressed, white hairs to c. $2 \mathrm{~mm}$ long. Leaves: petiole 3-8 mm long, 1-5 $\mathrm{mm}$ diam; lamina narrowly obovate to narrowly elliptic, $5-15$ by $2-5 \mathrm{~cm}$ (leaf index 2.6-3.4), coriaceous, not verruculose, shiny and dark olive-green to brown above, dull green ('glaucous') below, glabrous or rarely with scattered erect or appressed hairs above and below, base acute, sometimes obtuse and oblique, apex acute to shortly acuminate (acumen 5-10 mm long), primary vein slightly impressed above, secondary veins distinct, 


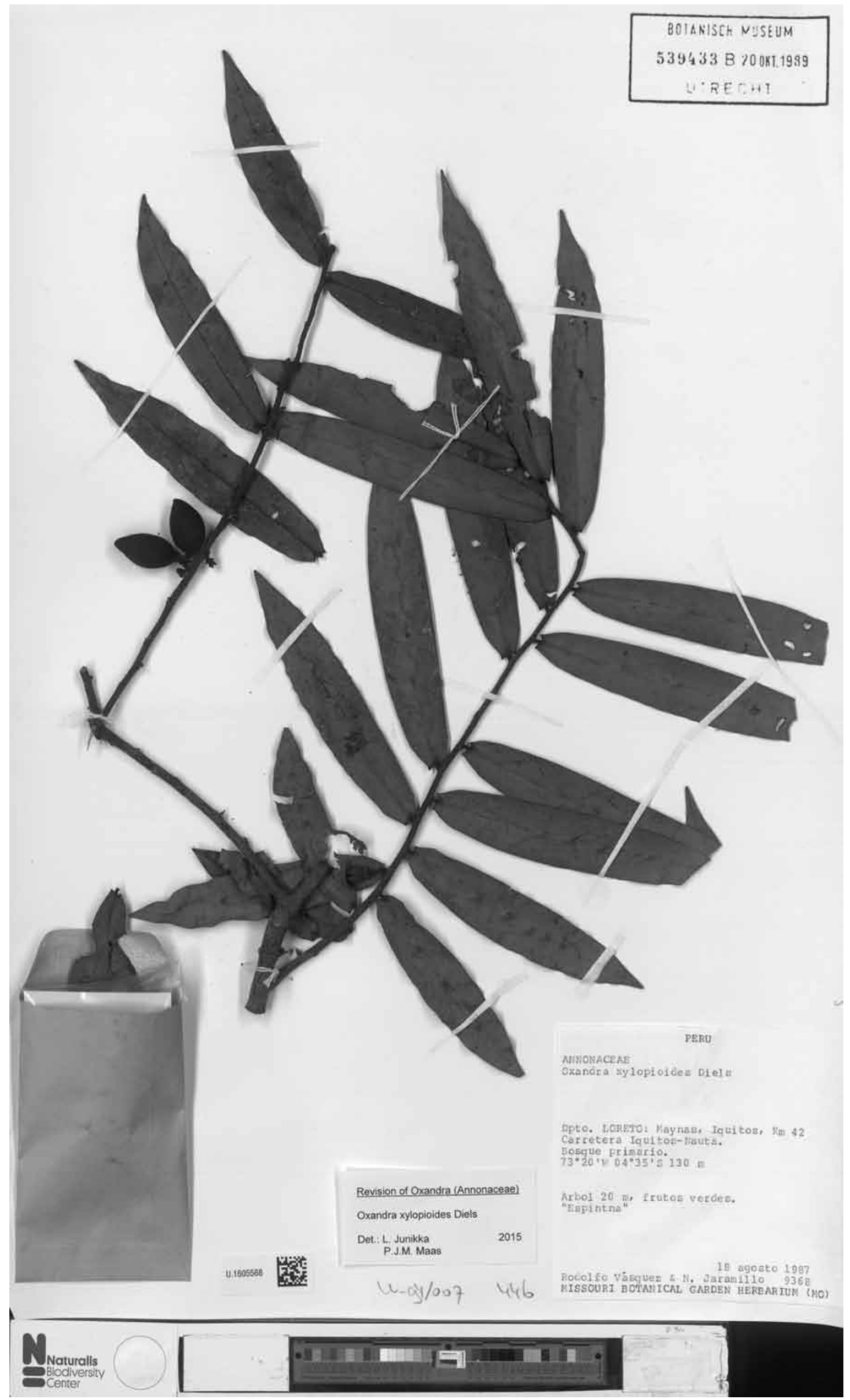

Fig. 25 Oxandra xylopioides Diels. Fruiting twig (Vásquez \& Jaramillo 9368, U). 
$10-13$ on either side of primary vein, raised above, angle of secondary veins with primary vein $45-65^{\circ}$, smallest distance between loops and margin $2-3 \mathrm{~mm}$, tertiary veins raised above, reticulate. Flowers in 1-10-flowered inflorescences, sometimes produced from leafless branches; pedicels c. $1.5 \mathrm{~mm}$ long, c. $1.5 \mathrm{~mm}$ diam, fruiting pedicels $3-10 \mathrm{~mm}$ long, $1-3 \mathrm{~mm}$ diam, densely covered with appressed hairs; bracts 5-6, depressed ovate, 1-2 mm long, outer side densely covered with appressed hairs; flower buds globose; sepals shallowly ovate-triangular, 2-4 by 2-4 $\mathrm{mm}$, outer side densely covered with appressed hairs; petals white to cream in vivo, elliptic to obovate, 8-14 by $4-7 \mathrm{~mm}$, outer side densely covered with appressed and erect hairs; stamens c. 50, 3-4 mm long, apex of connective narrowly triangular; carpels $\leq 20$. Monocarps $4-15$, green, maturing purple-black in vivo, black to brown and often glaucous in sicco, ovoid to ellipsoid, $10-19(-25)$ by $6-10(-12) \mathrm{mm}$, sparsely covered with appressed to erect, minute, white hairs, c. $0.1 \mathrm{~mm}$ long to glabrous, apex rounded, wall $0.5-1 \mathrm{~mm}$ thick, stipes $3-10$ by $1-2 \mathrm{~mm}$. Seed ellipsoid $12-15(-19)$ by $6-8 \mathrm{~mm}$, brown, surface transversely striate, ruminations lamellate in 4 parts.

Distribution - Mexico (Chiapas), Nicaragua, Costa Rica, Panama, Colombia (Antioquia, Bolívar, Cesar, Santander), Venezuela (Amazonas, Mérida, Táchira, Zulia).

Habitat \& Ecology - In non-inundated, moist forest. At elevations of 0-1100 m. Flowering: April, October, December; fruiting: February to April, September, December.

Vernacular names - Colombia: Yaya pino (De Bruijn 1608), Yaya sangre (Cogollo et al. 4594). Costa Rica: Haya (Thomsen 566), Yaha (Seeman 1580), Yayo (Estrada \& Rodríguez 234, Thomsen 566), Yayo amarillo (Thomsen 566), Yayo blanco (Thomsen 566). Nicaragua: Palanco (Grijalva \& Almanza 3601, Sandino et al. 3852, 5020). Panama: Yaya (Holdridge 6216). Venezuela: Ya-ya or Ya-yá (Aristeguieta et al. 6766, Bernardi 1923, 6359, Steyermark et al. 122914, 123099), Yaya pino (De Bruijn 1608).

Uses - Lo utilizan para 'pluma' entre el camion y el chuto (Aristeguieta et al. 6766, Venezuela); wood used for ax shafts (Thomsen 566, Costa Rica); se utiliza en la construcción de ranchos (Costa Rica: Zamora et al. 2000: 236).

Field observations - Flores aromaticas (Sandino et al. 5020, Nicaragua).

Notes - Oxandra venezuelana is recognized by often narrowly obovate leaves with a slightly impressed primary vein, a shiny upper side in which the tertiary venation is strongly raised and reticulate and a dull and glaucous lower side. Other features are the densely hairy petals and the high number of stamens

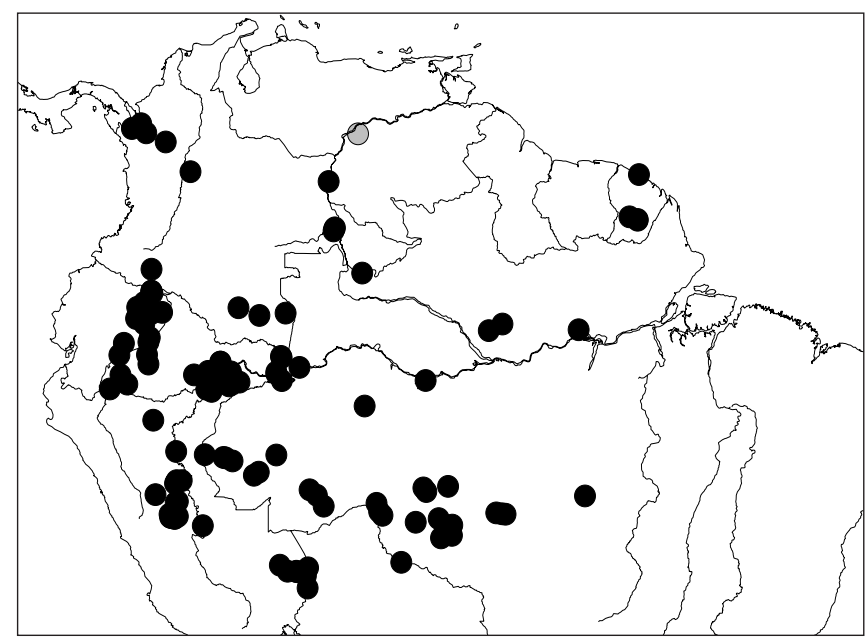

Map 13 Distribution of Oxandra xylopioides (๑) and Oxandra sp. Fernan$\operatorname{dez}(\bigcirc)$. (c. 50!). The monocarps in this species are often glaucous and covered with an indument of minute, appressed and erect hairs.

A sterile collection from Costa Rica, Poveda A. $3889(\mathrm{~F})$ is aberrant in having the young twigs densely covered with erect, brown hairs.

As already remarked in the Introduction, O. venezuelana in a study by Pirie et al. (2006) comes out in an isolated clade sister to Pseudomalmea diclina. Apart from the seeds which match quite well, there is hardly any resemblance between the two taxa, e.g. O. venezuelana: pedicels $<2 \mathrm{~mm}$ long in flower, $\leq 10$ $\mathrm{mm}$ in fruit, flower buds closed, vs $P$. diclina: pedicels 18-55 $\mathrm{mm}$ long in flower, $\leq 90 \mathrm{~mm}$ in fruit, flower buds open.

\section{Oxandra xylopioides Diels - Fig. 21g, h, 25; Map 13}

Oxandra xylopioides Diels (1927) 172. — Type: Tessmann 4572 (holo B; iso NY, US), Peru, Loreto, Upper Río Marañon, near mouth of Río Santiago, Pongo de Manseriche, 160 m, Nov. 1924.

Oxandra major R.E.Fr. (1937) 282, f. 10j, syn. nov. - Type: Krukoff 8497 (holo NY; iso BR, F, G, K, MICH, MO, NY, P, S, U), Brazil, Amazonas, Basin of Rio Solimões, Mun. São Paulo de Olivença, near Palmares, 11 Sept. -26 Oct. 1936.

Tree 3-45 m tall, 2-70 cm diam; young twigs densely covered with appressed to erect, brown hairs, soon glabrous. Leaves: petiole 1-4 $\mathrm{mm}$ long, 1-2 $\mathrm{mm}$ diam; lamina narrowly oblongelliptic to narrowly ovate, $4-20$ by $1-5 \mathrm{~cm}$ (leaf index $3.6-8$ ), chartaceous, totally verruculose above and below, the verruculae often string-forming, dull above, greyish brown to brown above and below, glabrous above, sparsely covered with appressed hairs below, soon glabrous, base with two distinct angular to tooth-like projections on either side, apex long-acute, primary vein impressed above, secondary veins indistinct and almost invisible, $10-16$ on either side of primary vein, flat above, angle of secondary veins with primary vein $45-80^{\circ}$, smallest distance between loops and margin $2-3 \mathrm{~mm}$, tertiary veins indistinct, almost invisible, flat above, reticulate. Flowers in 1-7-flowered inflorescences; pedicels 1-2 mm long, c. $1 \mathrm{~mm}$ diam, fruiting pedicels $2-5 \mathrm{~mm}$ long, $1-3 \mathrm{~mm}$ diam, glabrous; bracts 5-8, depressed ovate, 1-2 mm long, outer side rather densely to sparsely covered with appressed hairs; flower buds ellipsoid; sepals shallowly ovate-triangular, $1.5-2$ by $2-3 \mathrm{~mm}$, outer side sparsely covered with appressed hairs to glabrous; petals yellow, cream, or white in vivo, elliptic to ovate, $7-8$ by 3-4 $\mathrm{mm}$, outer side sparsely covered with appressed hairs; stamens 9-16, 2-3 mm long, apex of connective narrowly to broadly triangular; carpels $\leq 9$. Monocarps $1-8$, green-orange, maturing red, wine-red to black in vivo, black in sicco, obovoid, ellipsoid or subglobose, 13-25 by 9-14 mm, glabrous, apex rounded to apiculate (apiculum $<0.5 \mathrm{~mm}$ long), wall $0.5-2$ $\mathrm{mm}$ thick, stipes $1-4$ by $1 \mathrm{~mm}$. Seed ellipsoid, $10-18$ by $8-10$ $\mathrm{mm}$, brown, surface minutely pitted to transversely striate, ruminations spiniform.

Distribution - Bolivia (La Paz, Pando), Brazil (Acre, Amazonas, Mato Grosso, Pará, Rondônia), Colombia (Amazonas, Antioquia, Chocó, Cundinamarca, Vaupés), Ecuador (MoronaSantiago, Napo, Pastaza, Sucumbios), French Guiana, Peru (Amazonas, Huánuco, Loreto, Madre de Dios, Pasco, Ucayali), Venezuela (Amazonas).

Habitat \& Ecology — In non-inundated (terra firme) or periodically inundated (várzea) forest, or gallery forest, on sandy to clayey, red to yellow soil. At elevations of $0-450 \mathrm{~m}$. Flowering: from June to February; fruiting: all year through.

Vernacular names - Brazil: Envira-preta (Figueiredo 846), Envira-vassourinha (Silveira et al. 887), Inviera (Campbell et al. 6125), Invira-preta (Krukoff 8093). Colombia: Cargero (Van Dulmen 389), Faak+o cugao (Muinane name, Murillo \& Rodríguez A. 564), Fatrriocugao (Muinane name, Urrego et al. 248), Popai de culebra (Urrego et al. 248), T+raña (Huitoto 


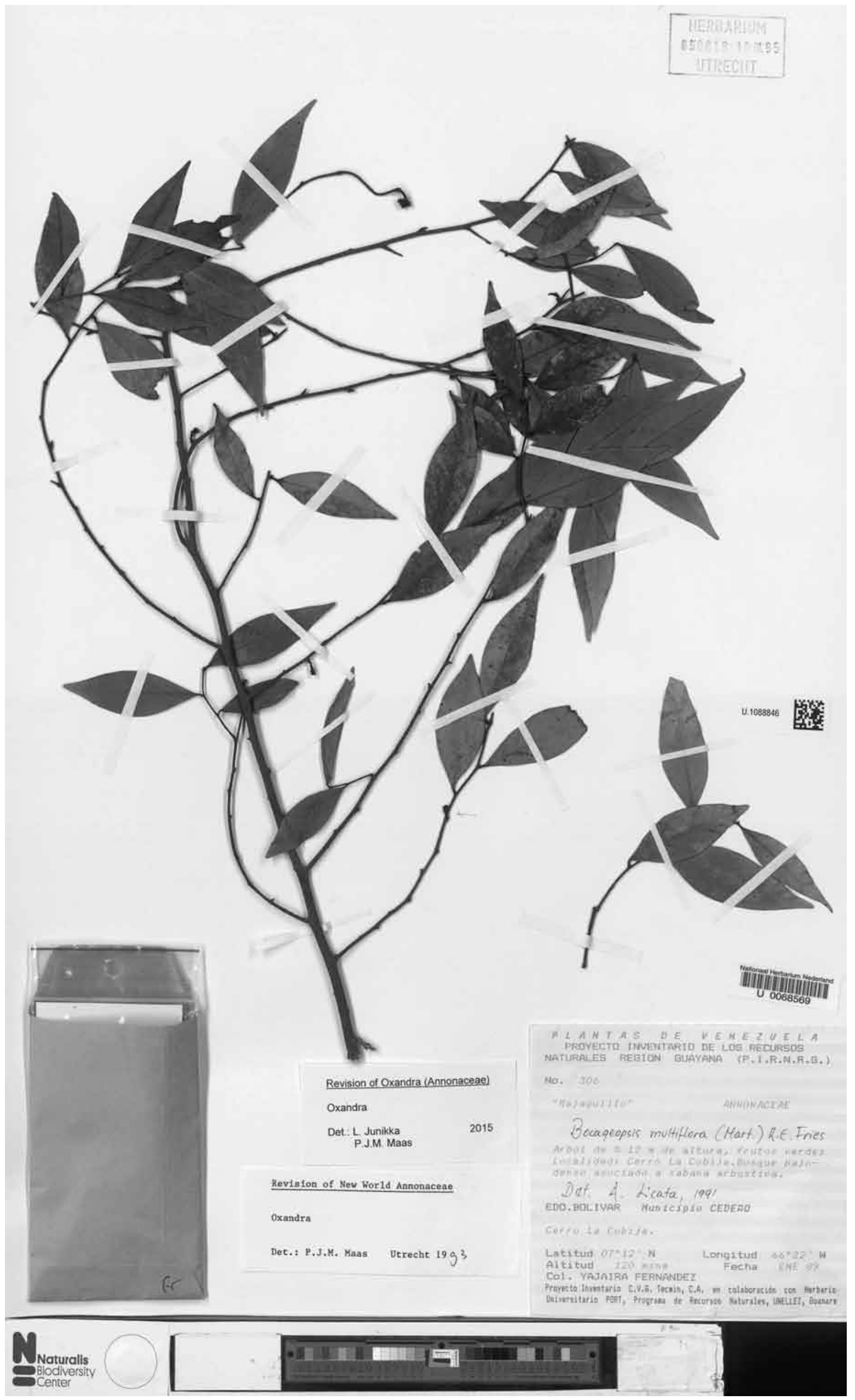

Fig. 26 Oxandra sp. Fernández. Fruiting twig (Y. Fernández 306, U). 
name, Murillo \& Román 583). Ecuador: Kaya yais (Shuar name, Anananch RBAE 127), Rumi cara caspi (Quichua name, Neill \& Rojas 10020), Yais (Shuar name, Kunkumas RBAE 209). French Guiana: Pendje ku (Boni name, Sauvain 342). Peru: Espintana (Jenssen S. 39, 40, Lao M. 8, T.D. Pennington et al. 16996, Reynel R. 166, Rimachi Y. 4350, Ruiz M. \& Jaramillo 1124, J.M. Schunke 94, Soria S. s.n., Vásquez et al. 7421, 8151, 8308, 9368, 10361, 10362, 11822, LI. Williams 4134), Espintana amarillo (Rimachi Y. 2920), Espintana negra (Acosta Malpica 46, McDaniel \& Rimachi Y. 20313, Pariona \& Ruiz M. 1034, 1041), Espintana negro (Gentry et al. 36293, 41378), Espintano (Killip \& Smith 28317), Kayayaís (Kayap 964), Kaya yaais (Shuar name, Ancuash A. 362), Kaya yais (Shuar name, Ancuash A. 468, Tunqui 172), Kaya yeis (Huambisa name, Huashikat 1170, 1257, 1519), Pinsha caspi (Ellenberg 2916), Pinsha cayo (Reynel R. 751), Pintana (R.B. Foster \& Wright 8150), Pintana negra (Alexiades 86PEM004, Hartshorn \& Quijano 2948), Yahuarachi caspi (Rimachi Y. 3128).

Uses - Usos como material de construccion para casas (Acosta Malpica 46, Peru); construção civil (Figueiredo 846, Brazil); used in rural house construction (Foster \& Wright 8150, Peru); se utiliza para madera (Huashikat 1257 and Tunqui 172, Peru); wood used for building houses (Killip \& Smith 28317 , Peru); sirva el tallo para hacer piesas para construer la casa (Kunkumas RBAE 209, Ecuador); madera para puntales de casas (Lao 8, Peru); vapor baths of leaves to treat fevers (Neill \& Rojas 10020, Ecuador); timber good for construction (J.M. Schunke 94, Peru); casca usada como envira (Silveira et al. 887, Brazil).

Field observations - Fruto con olor agradable (Brand \& Cogollo 49, Colombia); frutos con olor muy fuerte (Maceda 38 , Peru); flowers with strong aromatic and pleasant fragrance (Rainer 249, Peru).

Notes - Oxandra xylopioides is a much collected species, which is very easily recognizable by its narrow leaves (resembling certain species of Xylopia), which are totally verruculose (verrucae completely covering the leaf surface) and basally provided with two tooth-like projections. Moreover, the leaf venation is hardly visible.

It is closest to 0 . panamensis from which it differs by a leaf base generally with tooth-like projections. Moreover, the leaves are totally verruculose (hardly leaving any space in between) instead of densely verruculose (where the warts are separate with distinct space in between).

We have reduced O. major to a synonym of O. xylopioides as this is no more than a large-leaved form of the latter.

\section{UNPLACED SPECIMENS}

\section{Oxandra sp. - Fig. 26}

Y. Fernandez 306 (U; MO), Venezuela, Bolívar, Mun. Cedeño, Cerro La Cobija, 120 m, Jan. 1989.

Tree c. $12 \mathrm{~m}$ tall, diam not recorded; young twigs sparsely covered with erect hairs, soon glabrous. Leaves: petiole 1-3 mm long, $1 \mathrm{~mm}$ diam; lamina narrowly ovate to narrowly elliptic, 5-6 by $1.5-2 \mathrm{~cm}$ (leaf index $3-3.2$ ), chartaceous, rather densely verruculose on both sides to not verruculose, sometimes reddish punctate below, dull and greyish above, greyish brown below, glabrous above and below, base acute, apex bluntly acute, primary vein flat to slightly impressed above, secondary veins distinct, $6-8$ on either side of primary vein, raised above, angle of secondary veins with primary vein $40-50^{\circ}$, smallest distance between loops and margin 1-2 mm, tertiary veins raised above, reticulate. Fruits solitary; fruiting pedicels c. $3 \mathrm{~mm}$ long, $1 \mathrm{~mm}$ diam, glabrous; bracts 6-7, depressed ovate, 1$1.5 \mathrm{~mm}$ long, outer side glabrous; flower buds, sepals, petals, stamens and carpels not seen. Monocarps 2-5, green in vivo, black in sicco, globose, 5-6 mm diam, glabrous, apex rounded, wall $0.1-0.2 \mathrm{~mm}$ thick, stipes c. 1 by $1 \mathrm{~mm}$. Seed globose, 5$6 \mathrm{~mm}$ diam, brown, surface transversely striate, ruminations spiniform.

Habitat \& Ecology - In non-inundated, low forest, associated with tree savannah ('sabana arbustiva'). At an elevation of $120 \mathrm{~m}$. Flowering: not recorded; fruiting: January. 306).

Vernacular name - Venezuela: Majaguillo (Y. Fernandez

Note - This is a very incomplete fruiting collection. Some striking features are: tiny leaves with an almost flat primary vein and globose monocarps of only $5-6 \mathrm{~mm}$ diam. This is in our opinion, however, not sufficient to describe this material as a new species.

\section{EXCLUDED NAMES}

Oxandra nervosa R.E.Fr. (1939) 558. - Type: Krukoff 8792 (holo NY; iso F, MICH, MO), Brazil, Amazonas, Basin of Rio Solimões, Mun. São Paulo de Olivença, basin of Creek Belém, 26 Oct. -11 Dec. 1936. = Xylopia nervosa (R.E.Fr.) Maas in Maas et al. (1993).

Oxandra pachypetala Diels (1927) 173. - Type: Tessmann 4893 (holo B; iso F, G, NY, fragment S), Peru, Loreto, N of Río Apaga, basin of Río Marañon, 31 Dec. 1924 = Anaxagorea pachypetala (Diels) R.E.Fr.

Oxandra virgata auct non A.Rich.: Bello (1881) 234. = Guatteria caribaea Urb.

Acknowledgements We are indebted to the curators of the following herbaria, from where we borrowed or studied material: $A A U, A L C B, B, B P$, BR, C, CEPEC, COAH, COL, CUVC, CVRD, DUKE, E, F, FHO, G, GB, GOET, GUA, H, HBG, HRB, HUA, IAN, INPA, K, L, LE, LIL, LPB, MBML, MEXU, MG, MICH, MO, NA, NY, O, P, PR, R, RB, RUSU, S, SP, SPF, U, UC, ULM, US, VEN, VIES, WIS, WU, Z. We are also grateful to Esmée Winkel who prepared the drawing for this revision. The distribution maps in this publication were created using DMAP for Windows software written and supplied by Alan Morton (www.dmap.co.uk). Valuable assistance was given by: Curator Raino Lampinen and Mr. Pertti Rantiala regarding technical problems of map programming and finding coordinates for the collections and numerous Brazilian colleagues during the field work in Rio Janeiro (RJ), Santa Teresa (ES) and Ilhéus (BA). The first author thanks the foundation of Suomen Kulttuurirahasto, which funded his field trip to Brazil in 1999, and the Finnish Museum of Natural History, which enabled the visit of Paul Maas and Hiltje Maas-van de Kamer to Helsinki and the first author's visit to Leiden in 2015. He is also greatly indebted to the Botanical Unit of the Finnish Museum of History for their kind patience with LJ as he was finishing the time-consuming revision.

\section{REFERENCES}

Baillon H. 1868a. Histoire des plantes 1: 193-288. Hachette \& Cie, Paris, London, Leipzig.

Baillon H. 1868b. Mémoire sur la famille des Anonacées. Adansonia 8: 162184.

Bello y Espinosa D. 1881. Apuntas para la flora de Puerto-Rico. Anales de la Sociedad Española de Historia Natural 10: 234.

Bentham G. 1860. Notes on Annonaceae. Journal of the Proceedings of the Linnean Society. Botany. London 5: 67-72.

Bentham G, Hooker JD. 1862. Genera Plantarum 1, 1: 20-29. Black, London. Britton NL. 1889. An enumeration of the plants collected by Dr. H.H. Rusby in South America - IV. Bulletin of the Torrey Botanical Club 16: 14-15.

Chatrou LW, Pirie MD, Erkens RHJ, et al. 2012. A new subfamilial and tribal classification of the pantropical flowering plant family Annonaceae informed by molecular phylogenetics. Botanical Journal of the Linnean Society 169: 5-40.

Diels L. 1905. Anonaceae. In: Pilger R, Beiträge zur Flora des Hylaea nach den Sammlungen von E. Ule. Verhandlungen des Botanischen Vereins der Provinz Brandenburg 47: 125-136. 
Diels L. 1906. In: Urban I, Plantae novae andinae imprimis Weberbauerianae I. 9. Anonaceae andinae. Botanische Jahrbücher für Systematik, Pflanzengeschichte und Pflanzengeographie 37: 408-410.

Diels L. 1927. Anonaceae II. In: Mildbraed J, Plantae Tessmannianae peruvianae VI. Notizblatt des Botanischen Gartens Berlin-Dahlem 10: 169-177.

Dunal MF. 1817. Monographie de la famille des Anonacées: 1-145. Treuttel \& Würtz, Paris

Endress PK, Armstrong JE. 2011. Floral development and floral phyllotaxis in Anaxagorea (Annonaceae). Annals of Botany 108: 835-845.

Fries RE. 1906. Studien in der Riedel'schen Anonaceen-Sammlung. Arkiv för Botanik 5, 4: 1-24

Fries RE. 1931. Revision der Arten einiger Anonaceen-Gattungen II. Acta Horti Bergiani 10: 129-341.

Fries RE. 1934. Revision der Arten einiger Anonaceen-Gattungen III. Acta Horti Bergiani 12: 1-220.

Fries RE. 1937. Revision der Arten einiger Annonaceen-Gattungen IV. Acta Horti Bergiani 12: 221-288.

Fries RE. 1939. Revision der Arten einiger Annonaceen-Gatttungen V. Acta Horti Bergiani 12: 289-577.

Fries RE. 1948. Contributions to the flora of tropical America: XLVII. Annonaceae new to British Guiana. Kew Bulletin 1948: 229-235.

Fries RE. 1956. Some new contributions to the knowledge of the Annonaceae in Colombia and Mexico. Arkiv för Botanik n.s. 3: 433-437.

Fries RE. 1959. Annonaceae. In: Melchior H (ed), Die Natürlichen Pflanzenfamilien ... begründet von A. Engler und K. Prantl, ed. 2, Band 17 all: 1-171, f. 1-40. Duncker \& Humblot, Berlin.

Fries RE. 1960. In: Maguire B, Wurdack JJ, et al., The botany of the Guayana Highlands, Part IV. Memoirs of the New York Botanical Garden 10, 2: 22-23.

Grisebach AHR. 1861. Plantae Wrightianae e Cuba Orientali (Polypetalae et Apetalae). Memoirs of the American Academy of Arts and Science, n.s. 8, 1: 154.

Hickey L. 1979. A revised classification of the architecture of dicotyledonous leaves. In: Metcalfe CR, Chalk L (eds), Anatomy of the dicotyledons. 2nd ed. I: 25-39. Clarendon Press, Oxford

Jansen-Jacobs MJ. 1970. New species of Annonaceae from Suriname. Proceedings of the Koninklijke Nederlandse Akademie van Wetenschappen C 73: 336-342.

Junikka L, Koek-Noorman J. 2007. Anatomical structure of barks in Neotropical genera of Annonaceae. Annales Botanici Fennici 44 (Supplement A): 79-132.

Lopes JC, Junikka L, Mello-Silva R. 2013. Oxandra unibracteata (Annonaceae), a new species from the Atlantic Forest and a new synonym of $\mathrm{O}$. nitida. Phytotaxa 84: 25-30.

Lundell CL. 1941. Studies of American spermatophytes - I. Contributions from the University of Michigan Herbarium 6: 32-33.

Lundell CL. 1974a. Studies of American plants - VI. Wrightia 5, 2: 23-29.

Lundell CL. 1974b. Studies of American plants - VII. Wrightia 5, 3: 52-54.

Maas PJM, Koek-Noorman J, Westra LYT. 1993. Studies in Annonaceae XVIII. New species from the Neotropics and miscellaneous notes. Botanische Jahrbücher für Systematik, Pflanzengeschichte und Pflanzengeographie 115: 77-95.

Maas PJM, Maas-van de Kamer H, Junikka L, et al. 2001. Annonaceae from central-eastern Brazil. Rodriguesia 52: 61-94.

Maas PJM, Van Heusden ECH, Koek-Noorman J, et al. 1986. Studies in Annonaceae VII. New species from the Neotropics and miscellaneous notes. Proceedings of the Koninklijke Nederlandse Akademie van Wetenschappen C 89: 249-278.

Maas PJM, Westra LYT. 2003. Revision of the Neotropical genus Pseudoxandra (Annonaceae). Blumea 48: 201-259.

Maas PJM, Westra LYT, Arias Guerrero S, et al. 2015. Confronting a morphological nightmare: revision of the Neotropical genus Guatteria (Annonaceae). Blumea 60: 1-219.

\section{IDENTIFICATION LIST}

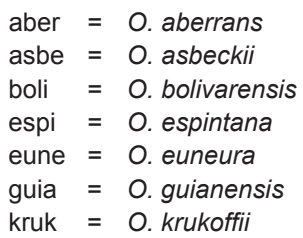

$\begin{aligned} \text { lanc } & =0 . \text { lanceolata } \\ \text { laur } & =0 . \text { laurifolia } \\ \text { leuc } & =0 . \text { leucodermis } \\ \text { long } & =0 . \text { longipetala } \\ \text { macr } & =0 . \text { macrophylla } \\ \text { mart } & =0 . \text { martiana } \\ \text { maya } & =0 . \text { maya }\end{aligned}$

Abbott, J.R. et al. 18874: lanc; 18930: lanc-Abbott, W.L. 2112: laur - Acosta Malpica 46: xylo - Aguilar \& Castro 762: xylo; 971: xylo; 1075: xylo - Aguilar F. et al. 3244: long; 5369: vene - Aizprúa et al. B 2275: pana; B 4078 : pana - Albán C. 3603: espi; 4109: espi; 5042: espi; 5541: espi; 5915A
Maas PJM, Westra LYT, Chatrou LW, et al. 2003. Duguetia (Annonaceae). Flora Neotropica Monograph 88.

Miranda F. 1961. Plantas nuevas del sur de Mexico. Boletin de la Sociedad Botánica de México 26: 120-123

Morawetz W, Waha M. 1986. Pollen-Ultrastruktur und Systematik bei Cremastosperma und Oxandra (Annonaceae). Sitzungsberichten der Österreichische Akademie der Wissenschaften. Mathematisch-naturwissenschaftliche Klasse. Abteilung 1, 195. Bd. 6. bis 10. Heft: 309-314.

Murray NA. 1993. Revision of Cymbopetalum and Porcelia. Systematic Botany Monographs 40: 1-121.

Pereira E, Pabst GFJ. 1977. Novitates herbarii Bradeani - 1. Bradea 2: 209-211.

Pirie MD, Chatrou LW, Mols JB, et al. 2006. 'Andean-centred' genera in the short-branch clade of Annonaceae: testing biogeographical hypotheses using phylogeny construction and molecular dating. Journal of Biogeography 33: 31-46.

Prantl K. 1891. Annonaceae. In: Engler A, Prantl K (eds), Die Natürlichen Pflanzenfamilien III, 2. Abteilung: 23-39. Engelmann, Leipzig.

Pulle AA. 1909. Neue Beiträge zur Flora Surinams II. Receuil des Travaux Botaniques Néerlandaises 6: 262-263.

Radford AE, Dickison WC, Massey JR, et al. 1974. Vascular plant systematics. Harper \& Row, New York

Richard A. 1841. Plantes vasculaires. In: De la Sagra R (ed), Histoire physique, politique et naturelle de l'lle de Cuba. Botanique: 27-56. Arthus Bertrand, Paris.

Roth I. 1981. Structural patterns of tropical barks. In: Braun HJ, Carlquist S, Ozenda P, et al. (eds), Handbuch der Pflanzenanatomie 9, 3: 160-162, 387.

Rusby HH. 1920. Descriptions of three hundred new species of South American plants: 18-20. New York, published by the author.

Sánchez Sáenz M. 1997. Catálogo preliminar comentado de la flora del Medio Caquetá. In: Saldarriaga JG, Van der Hammen T, et al. (eds), Estudios en la Amazonia colombiana XII: 46-61. Tropenbos Colombia.

Sessé M, Moçiño JM. 1894. Flora mexicana, ed. 2: 133-134. Officina tipográfica de la secretaría de Fomento, México.

Stearn WT. 1992. Botanical Latin, ed. 4. David \& Charles, London.

Steyermark JA, Maas PJM, Berry PE, et al. 1995. Annonaceae. In: Berry PE, Holst BK, Yatskievych K (eds), Flora of the Venezuelan Guayana 2: 413-469. Timber Press, Portland, Oregon.

Systematics Association Committee for descriptive biological terminology. 1962. II. Terminology of simple symmetrical plain shapes. Taxon 11: $145-146$.

Swartz O. 1788. Nova genera et species plantarum seu prodromus ...: 87 . In Bibliopoliis Acad. M. Swederi, Stockholm, Upsala \& Abo.

Swartz O. 1800. Flora Indiae occidentalis 2: 999-1002. Sumtu Jo. Jacobi Palmii, Erlangen.

Triana J, Planchon JÉ. 1862. Prodromus florae novo-granatensis. Annales des Sciences Naturelles; Botanique, Sér. 4, 17: 36.

Van Heusden ECH. 1992. Flowers of Annonaceae: morphology, classification and evolution. Blumea, Suppl. 7: 1-218.

Van Setten AK, Koek-Noorman J. 1992. Fruits and seeds of Annonaceae. Morphology and its significance for classification and identification. Studies in Annonaceae XVII. Bibliotheca Botanica 142: 1-101; pl. 1-50.

Von Schlechtendal DFL. 1834. De Anonaceis Brasiliensibus Herbarii Regii Berolinensis. Linnaea 9: 315-331.

Walker JW. 1971. Pollen morphology, phytogeography, and phylogeny of the Annonaceae. Contributions of the Gray Herbarium 202: 1-132.

Warming E. 1873. Symbolae ad floram Brasiliae Centralis cognoscendam. Particula XVI. Videnskabelige Meddellelser fra Dansk Naturhistorik Forening Kjøbenhavn 1873: 142-161.

Zamora VN, Jiménez QM, Poveda ALJ, et al. 2000. Arboles de Costa Rica II: 236. INBio, Santo Domingo de Heredia (CR).

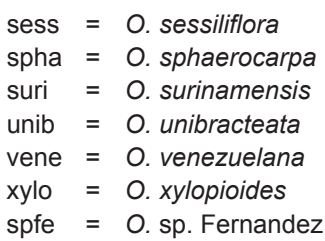

espi - Albuquerque et al. 231: ried; 469: ried cf.; 551: ried; 744: ried cf. - Alencar 548: sess; 718: sess - Alexiades et al. 53: medi; 60: medi; 89: medi; 98: medi; 112: medi; 152: medi; 160: medi; 164: medi; 197: medi; 203: medi; 274: medi; 280: medi; 291: medi; 295: medi; 299: medi; 302 
medi; 309: medi; 322: medi; 326: medi; 335: medi; 367: medi; 370: medi; 380: medi; 385: medi; 403: medi; 447: medi; 521: medi; 627: medi; 703 medi; 775: medi; 781: medi; 809: medi; 825: medi; 86PEM004: xylo - Allemão e Cysneiro, F. 10: sess - Allen 769: vene - Almeida, S.S. 329: ried; 344: ried; 349: ried -Almeida, V.C. 207: espi cf.; 208: mart - Altamirano A. 4035: xylo - Alvarenga et al. 1292: saxi-Amaral, D.D. et al. 155: reti; 476 kruk - Amaral, I.L. et al. 556: ried; 686: ried; 910: medi - Anananch RBAE 127: xylo - Ancuash A. 362: xylo; 468: xylo - André 1897: espi - Ange 40: asbe - Araujo M. et al. 508: espi; 1383: espi; 1740: espi; 2554: espi Arévalo et al. 59: leuc - Aristeguieta et al. 6766: vene - Armistead 1208: leuc; 1253: leuc; 1259: leuc - Asprey 2207: lanc - Assis et al. 381: espi; 721: espi - Atwell \& Moestl 4: laur - Aulestia et al. 748: poly; 1578: medi; 1934: xylo; 2126: ried - Ayala F. et al. 2266: xylo; 3496: medi - Aymard C. et al. 9409: espi; 10241: espi; 10944: eune; 11016: xylo; 11042: eune; 11231: xylo.

BAFOG (Service Forestier Guyane Française) 4356: asbe - Bahia, R.P. 117: kruk - Bahia, T.R. 74: eune; 2324: kruk; 2333: kruk; 2387: kruk; 2395: kruk; 2403: kruk; 2419: kruk; 2453: kruk; 2464: kruk; 2467: kruk - Balslev et al. 97093: eune - Bamps 5202: kruk; 5234: kruk; 5332: kruk - Baraloto et al. 518: asbe; 3330: asbe; 3332: asbe; 3333: asbe; 3334: asbe - Barbier 24: ried - Barbosa 400: espi - Barroso \& Guimaraes 23: sess - Bastos 2168: reti - Beard 460: laur - Begazo 72: xylo - Belém \& Mendes 116: saxi - Bell \& Phillips 88-189: poly - Berg et al. P 19834: xylo - Bernardi 1923: vene; 6359: vene - Berry et al. 6283: xylo; 6887: eune; 7358: eune; 7487: eune; 7528: eune - Betancur \& Velásquez 1745: medi - Bilby et al. 13: xylo - Billiet \& Jadin 1220: asbe; 8365: asbe - Black et al. 47-2036: kruk; 54-16717: reti - Blanc 118: asbe - Bloch \& Valencia 67526: xylo; 68584: eune - Boom \& Mori 1657: asbe; 1779: asbe - Boon 1184a: sur - Bordenave et al. 2612: asbe; 5043: asbe; 8120: suri; 8149: suri; 8179: suri - Braga 1310: espi - Brand M. et al. 49: xylo; 248: xylo; 764: xylo; 839: xylo; 1240: xylo; 1311: xylo - Brandbyge et al. 32790: medi; 36096: xylo - Breteler 4819: asbe - Brewer et al. 717: maya; 902: maya; 1054 maya; 1229: maya - Bristan 1129: pana; 1207: pana; 1345: pana - Britton et al. 686: lanc; 4903: laur; 5212: laur; 9725: laur; 12491: lanc; 12643: lanc; 14650: lanc; 15132: lanc - Bucci \& Verano 1579A: saxi; 1580A: saxi - Bunting et al. 6908: vene; 9117: espi; 10300: vene - Burchell 8464: saxi - Bustamente 341: vene - BW ('Boschwezen Suriname') 1220: asbe; 2346: asbe; 3129: asbe; 3977: asbe; 5652: suri.

C.T.F.T. 31: asbe; 37: asbe - Cabrera et al. 917: lanc; 3488: lanc; 16448: leuc - Cadamuro \& Solacroup 135: asbe - Callejas P. et al. 4908: pana; 9343: rheo; 12558: rheo - Campbell et al. 6125: xylo; 6292: medi; 6802: xylo; 6934: xylo; 8149: medi; 8301: xylo; 8458: xylo; 8885: medi; 9000: medi; 9179: medi; 9195: medi; 9247: medi; 9637: medi - Campos V. et al. 5: espi; 87: espi; 104: espi - Capucho 419: ried; 448: ried; 558: kruk - Cárdenas L. et al. 1323: xylo; 1380: xylo; 1966: xylo; 4601: xylo - Cardiel et al. D 1091: eune - Carillo 185: xylo - Carlos et al. 1205: ried; 1267: xylo; 1310: medi; 1479: xylo - Carnevali \& Melgueiro 1528: espi - Casaretto 1939: espi - Castro D 43: eune - Castroviejo B. et al. 13503: long - Cayola P. et al. 157: espi; 1543: espi; 1754: espi; 1754c: espi; 2204: espi; 2289: espi; 2327: espi - Cerón M. et al. 200: medi; 4683: medi; 5178: xylo; 20734: medi; 21399: medi - Chagas \& Silva 349: reti - Chatrou et al. 13: poly; 114: long; 120: vene; 130: poly; 133: espi cf.; 145: espi; 150: poly; 152 medi; 204: macr; 215: poly; 235: eune; 249: eune - Chaves 1133415: sess - Choo 285: xylo - Choque A. et al. 36: espi - Christensen 71894 xylo; 72103: eune; 72293: eune; 72298: xylo; 72439: eune; 72493: eune; 72648: eune; 72937: eune; 72943: eune; 73079: eune; 82313: xylo; 82731: eune; 82732: eune; 82756: eune; 83332: xylo; 83522: eune; 83590: xylo; 83859: xylo - Cid F. et al. 1802: xylo; 2302: leuc; 2781: poly; 3161: ried; 3755: ried; 4613: medi; 4974: eune; 5308: medi; 5349: medi; 5426: eune; 5926: eune; 7302: leuc; 8071: xylo; 8090: kruk; 8520: asbe; 8959: medi; 8968: xylo; 9031: medi; 9644: kruk; 10495: espi; 10811: macr - Clase G. et al. 669: lanc; 4566: lanc - Coêlho, D. et al. 13: ried; 43: ried; INPA 81953: ried - Coêlho, L. 58: ried cf. - Coêlho, L.S. et al. 66: poly; 298: ried - Cogollo et al. 461: long; 843: long; 1307: long; 1447: vene; 1475: long; 1542: vene; 1589: long; 4594: vene - Combs 537: lanc - Contreras 3494: maya; 5379: maya - Coradin et al. 5898: sess; 6039: reti - Cordeiro 459: eune - Cornejo V. \& Balarezo 3315: poly - Costa, L.V. (BHCO 30609) s.n.: mart - Costa, R.M. 53: kruk - Croat et al. 601: espi; 687: espi; 18638: eune; 18738: eune; 19729: medi; 34500: long; 98050: espi - Crosby \& Matthews 15: lanc - Cuadros V. 3155: boli - Cuello 698: espi - Curtiss 701: lanc.

Da Luz 1: reti - Dalle 201: pana - Daly et al. 4400: asbe; 5068: spha; 5621: spha; 7729: espi; 8241: poly; 8591: poly; 8782: medi; 9392: poly; 10271: poly; 10840: macr; 10982: poly; 11115: espi; 11217: espi - Dambrós RB 344233: saxi - Davidse et al. 12773: espi; 12940: long cf.; 13127: espi; 13154: long cf.; 18833: vene; 36572: maya - Davidson, C. 5296: eune Davidson, D. 8533: medi - De Bruijn 1608: vene - De Foresta 474: asbe - De Granville C 41: asbe; 3217: asbe; 3217A: asbe; 3961: xylo; 14030: asbe - De la Sagra 388: lanc; 562: lanc; 623: laur; 726: lanc - Deago et al. 488: long; 536: vene - Defler 28: xylo; 29: xylo; 31: ried - Delgado 352: espi - Demuner et al. 4151: espi - Devia A. et al. 4011: poly; 4290: poly DeWalt 16: medi - DeWalt et al. 226: espi - Dias et al. 728: kruk; 802: kruk; 1405: medi; 8917: medi; 9525: xylo - Díaz, P. et al. 7: eune - Díaz, W. et al. 5803: espi - Dik et al. 698: ried; 934: medi; 1062: ried; 1114: ried; 1218: xylo - Dodge et al. 16968: long - Dodson \& Torres 2973: eune-Ducke MG 609: reti; MG 777: reti; MG 8877: poly; MG 11243: poly; MG 15862: kruk; RB 16441: ried; RB 18347: sess; RB 23698: eune; RB 23899: ried - Duke et al. 432: pana; 4850: long; 5058: pana; 5670: long; 6533: pana; 8046: pana; 8256: pana; 8419: pana; 8830: pana; 10257: pana; 10281: pana; 12893: pana; 14105: pana; 14242: pana - Duque \& Posada 10: leuc - Duss 47: laur; 3058: laur; 4180: laur - Dutrève 219: asbe; 338: asbe.

Ek et al. 805: guia; 833: asbe - Ekman 459: lanc; 1902: laur; 2306: lanc; 2743: laur; 3824: laur; 4178: lanc; 4308: laur; 4468: lanc; 4581: lanc; 5924: laur; 6051: laur; 6078: lanc; 6162: lanc; 6163: laur; 8561: lanc; 9466: lanc; 18460: laur; 19094: lanc - Ellenberg 2856: eune cf.; 2907: eune cf.; 2916 : xylo; 2921: eune; 2953: poly - Emperaire 2214: sess; 2214A: sess; 2236 : sess - Encarnación 25061: ried - Eparvier 110: asbe; 128: asbe - Espinoza et al. 165: ried; 187: xylo; 259: medi; 599: medi - Estrada C. \& Rodríguez G. 234: vene - Evans \& McDonnell, K. 3150: suri - Eyerdam 6: lanc.

Fabris 803: espi - Farney et al. 1267: espi; 1357: espi; 3456: espi - FDBG (= Forest Department British Guiana) 2727: asbe; 3124: guia; 3789: asbe; 4836: asbe; 5526: asbe; 5558: asbe - Feddema 1879: pana; 2099: pana - Fernandez 306: spfe - Fernández C. et al. 43: espi - Fernández-Pérez 5222: espi - Ferreira 296: poly - Figueiredo et al. 437: espi; 846: xylo Fleury 161: asbe; 347: asbe; 830: asbe; 1032: asbe - Flores G. \& Tello A. 435: medi; 523: medi; 546: medi; 649: medi; 703: medi; 724: medi cf.; 775: medi; 2053: medi - Florschütz \& Maas 2419: suri - Folli 545: unib; 2672: espi; 3753: mart; 3754: espi; 3832: mart; 3833: mart - Fonseca et al. 2403: saxi; 2987: saxi - Forero \& Jaramillo 493: boli - Forget 219: asbe; 220: asbe - Foster, P.F. et al. 357: ried; 439: ried - Foster, R.B. et al. 2926: long; 4435: eune; 8150: xylo; 11313: espi; 11763: poly; 12636 : medi; 13738: pana - Fournet 481: espi - Franca et al. 1545: reti; 1678 : sess - Freire, B. \& Naranjo 709: ried - Freire, E. et al. 2926: medi; 3543: medi - Freitas 10: spha - Freitas, C.A.A. \& Mota 373: eune - Froehner 118: xylo; 563: xylo - Fróes 11578: reti; 21259: eune; 26447: ried; 29662 : ried; 33724: ried - Fuentes C. et al. 3517: espi; 3673: espi; 5699: espi; 17757: espi; 17765: espi; 17776: espi; 17837: espi; 17916: espi; 18520: espi; 18523: espi; 18529: espi; 18532: espi; 18598: espi; 18639: espi; 18654: espi; 18676: espi; 18777: espi; 18812: espi; 18815: espi; 18997: espi - Fuertes 224: lanc; 380: laur.

Galdames et al. 2804: long - García 3633: lanc-Gardner 2316: reti - Gentle 1720: maya - Gentry et al. 2661: long; 2836: long; 3185: long; 3237: long; 3258: long; 3285: long; 3869: medi; 6673: long; 8686: long; 18346: ried; 24474: pana; 24934: eune; 25416: poly; 26113: eune; 26744: espi; 26823: medi; 26909: medi; 27833: medi; 27866: poly; 30029: xylo; 31776: xylo; 32003: poly; 36293: xylo; 37707: espi; 38069: medi; 39255: leuc; 41378: xylo; 41718: xylo; 42393: poly; 42768: poly; 43034: xylo; 43040: medi; 43116: macr; 43162: medi; 43319: espi; 43364: medi; 43470: medi; 43481: espi; 45629: medi; 45771: medi; 46224: xylo; 51333: xylo; 51343: xylo; 51498: poly; 54306: xylo; 54332: poly; 54488: poly; 55772: ried; 56151: spha; 57292: vene; 57460: boli; 57696: poly; 57729: poly; 57733: poly; 57766: poly; 57820: poly; 57985: poly; 57992: poly; 58018: xylo; 58061: poly; 58075: poly; 58083: xylo; 58126: xylo; 58133: poly; 60094: medi; 60575: boli; 65934: medi; 68626: medi; 68725: medi; 68827: medi; 68935: medi; 69437: medi; 69832: medi; 70526: xylo; 71376: lanc; 71430: lanc; 72118: poly; 72145: poly; 72197: poly; 78393: poly; 78395: poly; 78433: medi - Gill \& Whitford 9037: lanc - Giordano et al. 1284: espi - Glaziou 10226: espi - Gomez-Pompa 306: maya - Gottsberger \& Döring 14-19186: ried; 112-31186: ried - Goulding 81: poly cf.; 208: poly; 1152: medi; 1495 : medi - Graham et al. 637: medi; 817: medi; 1130: medi; - Grández R. et al. 216: spha; 489: medi; 1945: eune; 2070: spha; 2709: spha; 2890: spha; 3129: xylo; 3169: xylo; 3397: xylo; 3728: kruk; 3779: ried; 4064: kruk; 4124: medi; 4125: medi - Grenand 3012: asbe - Greuter \& Rankin, R. 26600: lanc - Grijalva et al. 277: medi - Grijalva P. \& Almanza 3601: vene - Gudiño J. et al. 389: xylo; 2003: medi; 2086: medi; 2338: medi Guedes, M.L. et al. 2863: reti - Guedes, R. et al. 2256: mart - Guerrero C. et al. 1240: lanc - Guillén V. et al. 2054: ried; 2885: ried; 3113: ried; 3146: ried - Gutierrez C. et al. 541: ried.

Hahn 3740: asbe - Hallé 2753: asbe; 2755: asbe; 2779: asbe; 2781: asbe Hammel et al. 5415: long;16334: pana; 16590: pana; 18904: vene; 20855: vene - Harley et al. 16751: reti; 21155: reti; 25157: reti - Harris 6860: lanc; 6863: lanc; 7099: lanc; 8613: lanc; 9431: lanc - Hartshorn \& Quijano, J. 2948: xylo - Hatschbach et al. 49946: mart; 65943: reti; 67625: reti; 67719: reti; 67800: reti-Hayes 385: long; 599: long-Hedin 58: poly - Henderson et al. 309: eune-Hequet 1003: asbe - Hinojosa O. 1168: espi - Hinton et al. 16177: lanc - Hioram 4224: lanc - Hoffman et al. 1463: guia - Holdridge 6213: long; 6216: vene - Holst 5411: maya - Howard 5155: lanc - Hua- 
mantupa C. et al. 2611: ried; 2635: ried; 2637: ried; 12313: xylo - Huashikat 1170: xylo; 1257: xylo; 1519: xylo - Huber et al. 394/1: espi; 406/16: espi; 422: espi - Huft et al. 1951: pana - Hurtado Neill 1455: medi.

Ibañez et al. 764: vene - Irwin et al. 21132: sess; 21255: reti - Isert 312: laur Jack 5298: lanc; 5349: lanc; 5434: lanc; 5548: lanc; 5787: lanc - Jacquemin 2151: asbe; 2151 bis: asbe; 2161: asbe - Jaramillo A. et al. 6926: eune; 9097: eune; 14686: eune - Jardim \& Cadden 2142: saxi - Jenssen S. 39 xylo; 40: xylo - Jiménez R. et al. 1480: laur; 1587: laur; 1820: laur - Johann 113-20888: xylo - Johnston 1727: long - Julliot 127: asbe.

Kayap 964: xylo - Kelly 1596: lanc - Kennedy \& Breedlove 1422: aber Killeen et al. 6660: ried; 6881: ried; 6951: ried - Killip \& Smith 28029: eune; 28036: eune; 28317: xylo; 28752: macr-Klug 135: eune; 3814: espi; 4273 : espi - Knab-Vispo et al. 676: espi - Knob et al. 1201: eune - Korning \& Thomsen 9080: medi - Kröll Saldaña 146: medi; 157: medi; 183: medi; 536: medi; 537: medi; 538: medi; 540: medi; 545: medi; 648: medi; 650: medi; 655: medi; 657: medi; 664: medi; 754: medi; 762: medi; 771: medi; 777 medi - Krukoff 1124: kruk; 1372: xylo; 4628: macr; 4813: xylo; 5166: ried; 5181: medi; 5245: poly; 5331: espi; 5628: poly; 5706: espi; 6096: medi; 6471: ried; 6585: ried; 6784: eune; 8093: xylo; 8177: eune; 8447: xylo; 8497: xylo; 10132: espi; 10224: espi; 10281: espi - Kubitzki et al. 84-245 ried - Kuhlmann 2134: mart - Kunkumas RBAE 209: xylo - Kuno Rea 246 : eune - Kurtz et al. RB 328310: espi; RB 328312: mart.

Lanjouw \& Lindeman 2165: asbe; 2771: asbe - Lao M. 8: xylo - Lawesson et al. 44366: eune; 44440: eune - Leal (A07MA25) 25: ried - Lehmann 7986: lanc - Lems 5107: asbe; 5223: asbe - Léon Bro. (= Sauget-Barbier, J.S.) 9607: lanc; 12012: lanc; 22661: laur - Leonard \& Leonard 11306: lanc; 11685: lanc; 12513: laur; 15560: lanc - Lewis et al. 11155: xylo; 12486: xylo; 13100: xylo - Liesner et al. 4848: vene; 6983: leuc; 8882: leuc; 8949 : leuc; 17310: xylo - Lima et al. 191: poly cf.; 229: espi; 1048: xylo - Linares \& Balcázar 4261: pana; 4274: espi - Lindeman et al. 34: suri; 263: asbe; 346: asbe; 6988: asbe - Liogier et al. 11158: lanc; 13613: lanc; 14776: laur; 16623: lanc; 19047: laur - Lisboa et al. 1461: ried; 2487: medi - Little 13754: laur - Little et al. 495: xylo; 7601: espi; 8940: espi - Lombardi et al. 5138: espi - Lopes, C.G. 250: sess - Lopes, M.A. \& Andrade 840: mart López F. 551: lanc - Lott et al. 2895: lanc - Loubry 636: asbe; 714: asbe; 1734: asbe; 1761: asbe - Loureiro et al. 5299: ried cf.; (INPA) 37472: ried; (INPA) 38853: ried cf. - Loza R. et al. 432: espi - Luiz 442: eune - Luize 154: espi; 240: ried; 270: ried cf.; 296: ried; 851a: ried cf. - Luna 20: laur - Luteyn \& Foster 1373: long.

Maas et al. 5955: espi; 5956: espi; 6395: lanc; 6757: eune; 6879: eune; 7738: asbe; 8226: spha; 8234: eune; 8375: laur; 8820: espi; 8821: espi; 8839: espi; 8840: espi; 8962: asbe; 9184: asbe; 9349: asbe - Maceda 38 xylo - Macedo et al. 244: reti - Macía et al. 680: medi; 1201: ried cf.; 1354 medi; 1394: medi; 1480: ried cf.; 1678: medi; 1751: medi; 1934: medi; 1960: medi; 2403: medi; 2975: medi; 3547: xylo; 3565: medi; 3591: medi; 3787 ried cf.; 5511: medi cf.; 5652: espi; 5705: espi; 5777: medi cf.; 7651: espi - Maciel \& Rosário S. 1612: xylo - Madriñán et al. 1182: eune - Maguire et al. 56768: medi 56774: medi - Maldonado G. et al. 1508: espi; 1679: espi - Mamani M. et al. 1408: saxi - Marcano-Berti \& Peña S. 213-981: vene - March 1675: lanc; 1776: lanc - Marin 1589: espi - Marquete et al. 1867: espi - Martins TB 29: sess - Mathias 3931: espi - Matuda 18483 vene - McDaniel et al. 16244: poly; 20295: eune; 20313: xylo - McFarland 691: medi - McPherson 9246: long; 14982: pana - McVaugh et al. 1496: lanc; 19302: lanc; 20981: lanc - Medeiros et al. 1048: asbe; 1111 xylo - Mejía et al. 415: laur; 9416: lanc; 11224: laur; 13306: lanc; 23372 laur; 25251: laur - Mello 20: ried - Mendonça et al. 1: ried - Meneces \& Terceiros 129: espi - Mesquita 211: ried; 236: ried; 303: ried; 306: ried Miller 530: ried - Miralha et al. 103: eune; 137: xylo; 220: eune - Miranda, E.B. et al. 801: reti - Miranda, F. 8471/2: maya; 9147: lanc - Moestl \& Atwell 465: laur; 834: laur - Mohr \& Sosa 49: asbe - Molino et al. 762 asbe; 769: asbe; 1197: asbe; 1604: asbe; 1718: asbe; 1720: asbe; 1775 asbe; 1795: asbe; 1809: asbe - Monteagudo M. et al. 5754: medi; 5767 : ried; 6103: ried; 6202: medi; 6212: medi; 6244: medi; 6250: medi; 10493: xylo; 10762: xylo; 11576: xylo; 12672: medi; 12718: medi; 12768: medi; 14738: xylo - Monteiro, O.P. \& Damião 332: asbe - Monteiro, R.S. 190 reti - Moraes et al. 102: saxi - Morawetz \& Wallnöfer, B. 12-26988: poly; 12-51085: poly; 12-91085: poly; 13-25985: xylo; 15-26985: poly; 16-30985: espi; 21-24985: poly; 115-26985: poly; 118-221085: poly - Moreno 22134: long - Mori et al. 2660: pana; 3662: long; 8807: asbe; 8849: asbe; 9052: ried; 14753: asbe; 14884: asbe; 15170: asbe; 19280: ried; 22779: asbe; 23388: asbe; 23573: asbe - Morton 9874: lanc; 10453: lanc - Mouzinho \& Coêlho (INPA) 194302: ried - Muniz 96: reti; 302: reti; 305: sess cf.; B 2864: reti - Murillo \& Rodríguez 562: medi; 564: xylo - Murillo \& Román 583: xylo - Murray \& Johnson 1553: eune; 1565: eune.

Nadruz et al. 683: espi - Naranjo \& Freire 371: ried - Nascimento 717: eune Nash \& Taylor 1613: lanc - Nee 11372: long - Neill et al. 6647: medi; 6839 : xylo; 8270: xylo; 8490: medi; 8738: medi; 10020: xylo; 10316: ried - Nelson et al. 515: poly; 529: xylo; 568: poly - Normand 721: asbe - Núñez V. et al.
1711: medi; 1751: medi; 5313: long; 10633: espi cf.; 10665: medi; 10712: medi; 10748: medi; 10769: espi cf.; 10776: medi; 10777: medi; 10779: medi; 10840: medi; 10853: medi; 10958: medi; 11062: espi cf.; 11137: medi; 11458: espi; 12426: medi; 14239: espi; 15916: xylo; 16464: espi.

Oellgaard et al. 57185: medi - Ohba et al. 1228: medi - Oldenburger et al. 581: kruk - Oliveira, E. 1448: reti - Oliveira, F.C.A. et al. 2371: sess - Oliveira, J. et al. 506: eune - Oliveira, R. 34: espi - Oliveira et al. 766: poly - Olmsted et al. 63: lanc - Orlandi 379: saxi - Ornelas R. \& Luquín S. 1354: lanc.

Paget 34: asbe - Palacios, P. et al. 2703: eune - Palacios, W.A. et al. 2294: medi; 9263: eune; 9272: eune; 9301: eune; 9378: eune - Parada 42: saxi; 944: saxi; 969: saxi - Pardo et al. 54: ried - Paredes S. et al. 4: espi; 56 : espi; 1150: espi - Pariona \& Ruíz M. 1034: xylo; 1041: xylo - Paula 3430: reti - Peguero \& Veloz 179: laur - Pena \& Silva 46: poly - Pennell 4633: pana - Pennington, R.T. et al. 405: guia - Pennington, T.D. et al. 10576: medi; 10617: medi; 16996: xylo; 17022: spha - Pereira et al. 326: saxi; 1600: sess; 2999: saxi; 3288: saxi; 3340: saxi; 3467: saxi; 3641: saxi - PereiraSilva et al. 5664: saxi; 8942: sess - Pérez et al. 4951: ried - Persaud 339: asbe; 343 : asbe - Phillips et al. 66: espi; 128: espi; 277: poly; 340: medi; 354: medi; 355: medi; 373: medi; 394: medi; 485: medi; 495: medi; 508: medi; 682: poly; 683: poly; 684: poly - Picarda 1261: lanc - Pimentel \& García 981: laur - Pipoly et al. 8592: asbe; 8607 : asbe; 8793 : asbe; 8829 : asbe; 8952: asbe; 12247: eune; 13061: poly; 13076: espi; 13139: xylo; 13197: xylo; 13229: xylo; 13242: poly; 13248: xylo; 13370: xylo; 13422: poly; 13487: xylo; 13505: ried; 13519: xylo; 13546: ried; 13621: ried; 13636: poly; 13971: xylo; 14291: ried; 14435: xylo; 14635: xylo; 14728: xylo; 15798: xylo; 15824: poly; 16159: poly; 16277: poly; 16370: poly; 16429: poly Pires, J.M. et al. 3843: long; 7467: eune; 12458: sess; 12790: sess; 13363 : sess - Pires, O. \& Piata 249: ried cf. - Pirie, M. et al. 70: medi - Pitman et al. 1514: xylo; 3937: medi - Pittier 10857: espi cf.; 13296: espi cf. - Plée 790: laur; 898: laur - Plowman et al. 12190: eune; 12315: eune - Polak et al. 397: asbe - Poma C. 151: xylo - Poulsen 78028: xylo - Poveda A. 3889: vene - Prance et al. 2316: poly; 2538: poly; 3601: ried; 8290: eune; 8424: xylo; 16349: medi; 16455: eune; 16458: eune; 20612: ried; 22718: xylo; 24514: spha cf.; 25730: kruk; 25776: ried; 25831: kruk; 25849: kruk; 25882: kruk; 28083: asbe; (tree No. 215) s.n.: reti; (tree No. 248) s.n.: reti - Prata et al. 175: espi; 192: espi; 388: poly; 715: espi cf. - Prévost et al. 278: asbe; 598: asbe; 3095: asbe; 4421: asbe; 5234: asbe - Proctor 9482: lanc; 30104: maya; 31557: lanc; 36333: lanc - Purwanto 339: asbe; 1021: asbe; 1024: asbe; 1033: asbe.

Queiroz et al. 562: reti; 3649: reti; 12169: reti - Quevedo et al. 2372: ried Quispe et al. 30: espi; 99: espi; 101: espi; 113: espi; 136: espi; 151: espi; 182: espi; 295: espi; 317: espi; 405: espi; 440: espi; 454: espi; 482: espi; 490: espi.

Rainer 239: poly; 249: xylo - Ramos \& Mota 360: asbe; 362: ried - Ramos P. et al. 845: espi; 2305: espi - Rangel et al. 13587: xylo - Ratter et al. 7327: saxi; 7861: sess - Rea R. \& Kuno 320: espi; 338: espi - Rentería A. et al. 4264: xylo; 4316: xylo; 4342: xylo; 4482: xylo; 4536: pana; 4595: xylo; 4738: xylo; 4874: xylo - Rerts 351: espi - Revilla C. et al. 1299: eune; 1508: ried; 2337: eune - Reynel R. et al. 166: xylo; 227: espi; 751: xylo; 1276: medi; 5090: poly; 5262: poly; 5369: ried - Riedel 1389: ried - Riéra et al. 196: xylo; 233: asbe; 953: asbe; 968: asbe; 1307: asbe - Rimachi Y. 271: spha; 2920: xylo; 3045: poly; 3128: xylo; 4350: xylo; 4356: leuc; 6724 : spha; 7480: eune; 8083: poly; 8623: poly; 8818: leuc; 10019: spha - Ríos 3: espi - Rivera 299: long - Roberts 1: guia - Robleto T. 337: long; 938 : long; 1695: long - Rodrigues et al. 1006: eune; 2373: ried; 7739: ried; 8426: ried; 10286: sess - Rodriguez G. et al. 2124: vene; 4817: long - Rosa et al. 5325: ried; 5661: ried - Rosas et al. 277: xylo - Rubio 7: xylo - Rudas L. et al. 1578: xylo; 1715: medi; 1743: poly; 2538: xylo; 3002: medi; 3261: poly; 3282 : poly; 3493 : poly; 3517 : poly; 3527 : poly; 3579 : medi; 3630 : poly; 3631: medi; 3641: xylo; 3686: xylo; 3710: xylo; 3800: poly; 3813: xylo; 3917: medi; 3938: poly; 4011: poly; 4347: xylo; 4377: xylo; 4471: xylo; 4694: xylo; 4726: xylo; 4845: xylo; 5084: medi; 5178: xylo; 5203: xylo; 5235: xylo; 5336: xylo; 5441: xylo; 5542: xylo; 5570: xylo; 5619: xylo; 5799: medi - Rueda et al. 373: boli; 754: kruk; 18409: vene; 19367: vene - Rugel 76: lanc; 329: lanc - Ruíz M. et al. 627: eune; 696: eune; 1124: xylo; 1549: eune; 1552: eune - Rusby 47: espi; 2651: espi - Rzedowski 14862: lanc; 15322: lanc; 15474: lanc; 17917: lanc.

Sabatier et al. 136: asbe; 230: asbe; 454: asbe; 1788: asbe; 1802: asbe; 3927: asbe; 5317: xylo; 5321: xylo - Salazar \& Peguero 393: lanc - Salomão 1185: kruk; 1302: kruk - Sandino et al. 3852: vene; 5020: vene - Santos, A.A. et al. 399: saxi; 579: saxi - Santos, M.R. 205: ried - Santos, T.S. 964: espi; 1298: espi - Sarthou 393: asbe - Sasaki et al. 1774: xylo - Sauvain 23: asbe; 342 : xylo; 451 : asbe - Scarff $11 \mathrm{~F}$ : laur; $11 \mathrm{H}$ : lanc - Schaller 76 : reti; 208: reti - Schatz et al. 775: reti; 815: sess; 842: reti; 855: reti; 856: sess; 857: sess; 906: sess; 927: reti; 941: sess; 1088: vene - Schiffino 109: laur - Schultes \& Cabrera 16448: leuc - Schulz LBB 7667: asbe; LBB 8050: asbe - Schunke 94: xylo - Schunke V. 2344: espi; 4739: poly; 
9784: espi - Seeman 1580: vene - SEF (Studies of Ecuadorean forests) 9080: medi; 9224: medi - Seidel et al. 8497: espi-Sellow B 1970, C 1483 mart - Sevilha et al. 3779: saxi - Shafer 398: lanc; 2836: lanc; 3684: laur; 8894: laur; 10552: lanc; 10603: lanc; 11124: lanc; 12007: lanc; 12232 laur - Silva, A.S. et al. 25831: kruk; 25849: kruk; 25882: kruk - Silva, A.S.L. et al. 375: eune; 400: eune - Silva, F.C.F. 144: reti - Silva, I.A. 272 unib - Silva, M. et al. 753: ried; 1260: ried; 1892: ried; 2550: kruk; 2582 kruk - Silva, M.A. et al. 4608: saxi - Silva, M.F. et al. 1243: leuc; 1282 leuc; 1581: eune - Silva, M.F.F. et al. 1128: reti - Silva, M.G. et al. 3730: kruk; 3926: kruk; 4817: xylo; 6063: xylo; 6086: xylo; 6205: xylo - Silva, N.T. 1627: kruk - Silva, S.B. 98: reti; 193: reti - Silveira et al. 887: xylo; 973: espi; 985: poly; 1039: poly - Silverstone-Sopkin et al. 3398: espi; 5318: espi; 5471: espi; 5831: espi; 5879: espi; 6117: espi; 6167: espi; 6175: espi; 6274: espi; 6314: espi; 6337: espi - Simá 1268: lanc - Sintenis 794: lanc; 966: laur; 1350: laur; 4237: laur; 4313: laur; 6121: laur; 6166 laur - Smith, D.N. 8402: xylo - Smith, S.F. et al. 1025: poly; 1347: poly; 1475: poly - Soejarto 709: xylo - Solórzano 215: saxi - Soria S. (tree no. YU-34 PH) s.n.: xylo - Sothers et al. 23: poly; 52: espi - Soto S. et al. 215: vene - Sousa, J. 95: xylo - Souza, J.M.A. 150: ried - Souza, L.L. et al. 156: ried; 157: ried; 234: eune - Souza, M.A.D. et al. 785: ried - Souza, S.A.M. et al. 52: kruk; 802: kruk - Spruce 2311: eune cf.; 2461: leuc; 3352: leuc; 3549: leuc; 4920: espi - Stahel (Woodherbarium Suriname) 271: asbe - Stergios 18545: xylo - Stern et al. 202: pana; 739: vene; 945 pana; 1398 : pana 1793: long; 1818: long - Stevens et al. 22246: vene; 28907: pana - Stevenson 103: maya - Stevenson D. 24: medi - Steward et al. 283: ried - Steyermark et al. 55849: espi cf.; 86539: espi; 99947: vene; 119183: vene 122914: vene; 123099: vene - Stropp \& Assunção 480: eune - Sucre 4433: espi.

Tavares et al. 171: poly - Taylor, E.L. et al. E 1125: sess; E 1244: sess Taylor, N. 147: laur; 372: lanc - Teixeira et al. 659: xylo - Tello E. 331: medi; 513: medi; 1118: medi; 1150: medi; 1291: medi; 2942: medi; 2968 : medi; 2985: xylo - Terborgh \& Foster, R.B. 6216: medi - Tessmann 4572 xylo; 5320: eune; 5383: ried - Thiel 31: asbe; 37: asbe - Thomas, W.W. et al. 4963: xylo; 4985: xylo - Thomsen 566: vene; 1274: vene - Timaná et al. 1289: medi; 1734: espi cf.; 1755: medi; 2327: medi; 2491: medi; 2781 : medi; 2785: medi; 2803: medi; 3016: medi; 3019: medi; 3028: medi; 3157 medi; 3296: espi cf.; 3298: medi; 3451: ried - Toriola-Marbot 465: asbe Torrez F. et al. 24: espi - Tostain 1: asbe; 2: asbe - Tunquí 172: xylo; 192 : medi - Tyson et al. 2907: long; 2975: long; 4625: pana.

Ule 5796: medi; 9368: espi - University of Guyana - Course Neotropical Botany 34: guia; 55: asbe - Unknown collector 22: medi; 97: lanc - Ur- rego G. et al. 248: xylo; 425: ried; 643: asbe - Uzquiano E. et al. 40: espi; 57: espi; 152: espi.

Vageler A 13: pana - Valcarcel 539-2: spha - Valencia R. et al. 67330: eune; 67367: xylo; 67387: xylo; 67406: xylo; 67420: eune; 67523: xylo; 67526: xylo; 67632: xylo; 67635: xylo; 67641: xylo; 67803: xylo; 67933: eune; 68035: xylo; 68217: xylo; 68584: eune; 68678: xylo; 68679: xylo Valenzuela G. et al. 400: espi; 973: espi; 4220: medi; 9890: medi; 22204: spha - Van Andel et al. 441: eune; 4639: asbe - Van Asbeck BBS 81: asbe - Van Donselaar 1024: asbe; 3499: asbe - Van Dulmen 389: xylo; 428: leuc - Vargas et al. 146: medi - Vargas S. 670: vene - Vasconcelos et al. 266: kruk - Vásquez et al. 389: medi; 1163: eune; 1407: eune; 3129: ried; 3187: eune; 3356: medi; 3504: eune; 3551: ried; 3617: ried; 3913: xylo; 5001: spha; 5279: leuc; 5338: medi; 5390: eune; 5786: eune; 6014: poly; 6041: xylo; 6042: xylo; 6280: spha; 6386: spha; 6571: poly; 6659 : medi; 7297: xylo; 7341: leuc; 7421: xylo; 7583: eune; 7931: xylo; 7994: eune; 8151: xylo; 8208: ried; 8308: xylo; 8610: xylo; 9368: xylo; 10100: spha; 10361: xylo; 10362: xylo; 10581: eune; 11596: ried; 11822: xylo; 13422: ried; 14037: xylo; 14492: xylo; 15489: xylo; 15802: xylo; 15982: medi; 16276: eune; 16592: eune; 16890: ried; 17094: medi; 17750: eune cf.; 17901: eune cf.; 17978: eune cf.; 17986: eune cf.; 19117: poly; 19211: poly; 19288: poly; 20564: poly; 21750: medi; 22922: poly; 22999: medi; 23266: poly; 23336: medi; 23646: poly; 23741: poly; 25632: medi - Verboonen et al. 116: saxi - Victorio (RB 2547) 85: espi - Villa \& Vélez 838: ried - Villiers 5255bis: asbe; 5325: asbe - Von Eggers 2449: laur - Von Hermann 3283: lanc.

Wallnöfer 11-81188: poly; 11-171188: medi; 11-241088: xylo; 14-11088: poly; 17-14788: xylo - Walter et al. 2837: saxi; 3583: saxi - Warming (“Anon. No. 17") s.n.: mart - Weberbauer 1897: medi - Weddell 772: mart - Weiss 184: medi - Whitford \& Silveira 56: espi - Wijninga \& Quintero 623: eune - Williams, LI. 475: spha; 478: spha; 4129: macr; 4134: xylo; 13040: espi; 15559: espi - Williams, R.S. 217: espi; 669: pana; 1017: pana - Wood et al. 23525: saxi; 24589: saxi; 25096: saxi; 25544: saxi - Wright 4: laur; 342: lanc; 489: laur; 1101: laur; 1102: lanc - Wurdack \& Monachino 41405: espi - Wydler 423: laur.

Young 119: leuc.

Zak et al. 4190: spha; 4316: medi; 4333: xylo - Zambrano 2000: vene - Zanoni et al. 12011: lanc; 13443: laur; 13558: laur; 15235: lanc; 16423: laur; 17789: laur; 28517: lanc; 32160: lanc; 33142: laur; 34150: laur; 35994: laur; 38122: laur; 38504: lanc; 44669: lanc - Zartman 6206: eune - Zarucchi et al. 2752: xylo - Zuleta 318: medi.

\section{INDEX}

Accepted names are in roman type. New names are in bold type; synonyms and superfluous names are in italics. The number after each name is the number of the species as used in this revision; (excl.) refers to the excluded species. References to pages are given in square brackets.

Alphonsea Hook.f. \& Thomson [p. 215]

Amyris belizensis Lundell 14

Anaxagorea acuminata auct. 9 crassipetala [p. 218] pachypetala (Diels) R.E.Fr. (excl.)

Annickia Setten \& Maas [p. 215]

Annona L. [p. 218]

Annonoideae [p. 215]

Asimina-group [p. 215]

Bocagea aromatica (Triana \& Planch.) Britton 4 asbeckii Pulle 2

espintana Spruce ex Benth. 4 laurifolia (Sw.) Benth. \& Hook.f. 9 leucodermis Spruce ex Benth. 10 virgata (Sw.) Benth. \& Hook.f. 8

Bocageopsis R.E.Fr. [p. 215]

Cananga (DC.) Hook.f. \& Thomson [p. 215] lancea Poit. ex Dunal 8

laurifolia (Sw.) A.DC. ex Baill. 9 pseudolancea Poit. ex Dunal 9 virgata (Sw.) A.DC ex Baill. 8

Costaceae [p. 219]

Costus [p. 219]

Cremastosperma R.E.Fr. [p. 215, 216]

Cremastosperma alliance [p. 215, 218]

Cremastosperma-group [p. 215]

Cymbopetalum brasiliense (Vell.) Benth. ex Baill. [p. 219]

Drimys lancea Poit. ex Baill. 8

Duguetia A.St.-Hil. [p. 217, 218]

\section{Enantia Oliv. [p. 215]}

Ephedranthus S.Moore [p. 215, 216]

Guatteria Ruiz \& Pav. [p. 218, 233, 239, 261]

caribaea Urb. (excl.)

laurifolia (Sw.) Dunal 9

martiana Schltdl. 13

virgata (Sw.) Dunal 8

Klarobelia Chatrou [p. 215, 216]

Malmea R.E.Fr. [p. 215, 216]

Malmea s.I. [p. 215]

Malmea subfamily [p. 215]

Malmea tribe [p. 215]

Malmeoideae [p. 215, 216]

Miliusa Lesch. ex A.DC. [p. 215]

Mosannona Chatrou [p. 215, 216]

Onychopetalum R.E.Fr. [p. 215]

Oxandra A.Rich. [p. 220]

aberrans Maas \& Junikka 1

acuminata Diels 15

aromatica Triana \& Planch. 4

asbeckii (Pulle) R.E.Fr. 2

belizensis (Lundell) Lundell 14

bolivarensis Maas \& Junikka 3

espintana (Spruce ex Benth.) Baill. 4

euneura Diels 5

guatemalensis Lundell 14

guianensis R.E.Fr. 6

krukoffii R.E.Fr. 7

lanceolata (Sw.) Baill. 8

subsp. macrocarpa R.E.Fr. 8
Oxandra (cont.)

laurifolia (Sw.) A.Rich. 9

leucodermis (Spruce ex Benth.) Warm. 10

longipetala R.E.Fr. 11

macrophylla R.E.Fr. 12

major R.E.Fr. 27

martiana (Schltdl.) R.E.Fr. 13

maya Miranda 14

mediocris Diels 15

nervosa R.E.Fr. (excl.)

nitida R.E.Fr. 4

oblongifolia R.E.Fr. 16

opaca E.Pereira \& Pabst 4

ovata Rusby 4

pachypetala Diels (excl.)

panamensis R.E.Fr. 16

polyantha R.E.Fr. 17

proctorii Lundell 14

punctuata C.Wright ex Griseb. 8

reinhardtiana Warm. 13

reticulata Maas 18

rheophytica Maas \& Junikka 19

riedeliana R.E.Fr. 20

saxicola Maas \& Junikka 21

sessiliflora R.E.Fr. 22

sp. 2 Junikka 25

sp. A Steyerm. 4

sp. Fernandez [p. 261]

sphaerocarpa R.E.Fr. 23

surinamensis Jans.-Jac. 24 
Oxandra (cont.)

unibracteata J.C.Lopes, Junikka \& MelloSilva 25

venezuelana R.E.Fr. 26

virgata (Sw.) A.Rich. 8

virgata auct. (excl.)

xylopioides Diels 27

Pseudomalmea Chatrou [p. 215, 216, 259]

Pseudoxandra R.E.Fr. [p. 215, 216]

\section{LIST OF VERNACULAR NAMES}

For abbreviations, see p. 262

Acara-wasca (spha)

Anoncillo (espi)

Anshilo caspi (medi)

Arara (guia)

Ariticum-do-mato (espi)

Aso mato (asbe)

Atinha (reti)

Ayacbara (espi)

Bamba (asbe)

Baracaspi (eune)

Bi pao (asbe)

Black lancewood (lanc)

Bois de l'an (laur)

Bois de lance (lanc)

Cajao-dujeco (asbe)

Cajao-dujecu (poly)

Carahuasca (eune)

Cargero (xylo)

Carguero de sabana (poly)

Carguero de vara (asbe)

Chaporoasca (espi)

Chicoga narangal (espi)

Chilcahuite (lanc)

Chuchuhuasha mashan (macr)

Condurú (sess)

Corcho blanco (laur)

Cueronegro (eune)

Cundurú (sess)

Echte pikapika (asbe)

Eé-ña-moo-re (leuc)

Envira (ried)

Envira-branco-do-igapó (poly)

Envira-caniceira (espi)

Envira-de-tambaqui (poly, ried)

Envira-de-várzea (ried)

Envira-ferro (espi, poly)

Envira-fita (xylo)

Envira-preta (kruk, poly, xylo)

Envira-preta-desconhecida (ried)

Envira-preta-folha-media (ried)

Envira-surucucu (ried)

Envira-vassourinha (xylo)

Envireira-branca (ried)

Envireira-caniceira (espi)

Envireira-da-várzea (poly)

Envireira-forte (kruk)

Espintana (espi, eune, leuc, medi, poly, spha, xylo)

Espintana amarilla/o (eune, xylo)

Espintana blanca (espi)

Espintana hoja chiquita (espi)
Ruizodendron R.E.Fr. [p. 215, 216]

Sageraea Dalzell [p. 215]

Stafilinidios (=Staphilinidios) [p. 229]

subtribe Uvarieae Baill. [p. 215]

tribe Anoneae Endl. [p. 215]

tribe Malmeeae [p. 216]

tribe Miliuseae Hook.f. \& Thomson [p. 215]

tribe Piptostigmateae [p. 215]

tribe Uvarieae [p. 215]
Unonopsis R.E.Fr. [p. 215, 216]

Uvaria L. [p. 215]

Uvaria dodecandra Sessé \& Moç. 9

excelsa Vahl ex Dunal 8

lanceolata Sw. 8

laurifolia Sw. 9

virgata Sw. 8

Xylopia nervosa (R.E.Fr.) Maas (excl.)
Espintana negra/o (espi, medi, xylo)

Espintana roja (spha)

Espintano (xylo)

Dogui-có (poly)

Faak+o cugao (medi, xylo)

Fatrriocugao (xylo)

Fici-cu (eune)

Foedida (asbe)

Gie pawoe (asbe)

Gogó-de-guariba (poly)

Guácano (espi)

Hansoe matoe (asbe)

Haya (vene)

Imbiú-amarelo (espi)

Imbiú-mineiro (reti)

Imbiú-preto (mart, unib)

Inviera (xylo)

Invira-preta (xylo)

Jajobahi hãrãdo jeicobu (eune)

Juruqui (espi)

Juvueira-algodão (ried)

Karashiri (asbe)

Karishiri (asbe)

Kaya yais/yaais (xylo)

Kaya yeis (xylo)

Kayayaís (xylo)

Kepiseróki (medi)

Lancewood (lanc, laur)

Majagua (espi)

Majaguillo (sp. Fernandez)

Mamba (asbe)

Mejo-de-porco (saxi)

Mi-Pente (asbe)

Micha (Ese-ejha) (medi)

Misa (poly)

Moeamba (asbe)

Moemba (asbe)

Moncataweimo (medi)

Mouamba (asbe)

Mwamba (asbe)

Mwemba (asbe)

Nahuacté (maya)

Nahuate (maya)

Npomba (asbe)

Okra (laur)

Palanco (vene)

Palo paye (leuc)

Palo remo (espi)

Pantomo (ried)

Paujil micuna (poly)

Pendje ku (xylo)
Pikapika (asbe)

Pinda'ywa (kruk)

Pindaíba (mart)

Pindaíba-de-poste (mart)

Pindaíba-ferreira (espi)

Pindaípixuna (eune)

Pinsha caspi (xylo)

Pinsha cayo (xylo)

Pintana (medi, xylo)

Pintana colorada (medi)

Pintana negra (medi, xylo)

Piraquina (medi)

Piraquina negro (espi)

Piriquina colorada (medi)

Popai de culebra (xylo)

Purio (laur)

Rimo (espi)

Rumi cara caspi (xylo)

Sacha aceituna (poly)

Schopsteelenhout (asbe)

Singa colorada (ried)

Sipico yejperí (espi)

Sipicu (espi)

Sipiko (medi)

Sipiku negro (espi)

Taiassuba (kruk)

Tortuga (poly)

Tortuga caspi (eune, leuc)

Tortuga caspi amarillo (leuc)

T+raña (xylo)

Uichur-chichit (pana)

Uñitahue (medi)

Vara (leuc)

Vassourinha (medi)

Ya-yá (vene)

Yadayada (espi)

Yaha (vene)

Yahuarachi caspi (eune, xylo)

Yahuayachi caspi (spha)

Yais (xylo)

Yaiya (laur)

Yana tortuga (eune)

Yaya (lanc, laur, pana, vene)

Yaya boba/o (laur)

Yaya fina (lanc)

Yaya negra (pana)

Yaya pino (vene)

Yaya prieta (laur)

Yaya sangre (vene)

Yayo (vene)

Yayo amarillo (vene)

Yayo blanco (vene) 